\title{
BASELINE SURVEY MENGENAI KONDISI INTERNAL, PERSAINGAN DAN SISTEM PENGAWASAN BANK PERKREDITAN RAKYAT SYARIAH DI JAWA TIMUR
}

\author{
Djoko Sutrisno, Tjahjono \\ Mohamad Amin, Johny Marsius*)
}

\section{Pendahuluan}

\subsection{Latar Belakang}

Keberadaan lembaga keuangan mikro dalam perekonomian Indonesia, sebagaimana juga di negara-negara berkembang lainnya, cukup penting karena selama ini lembagalembaga keuangan mikro tersebut (termasuk Bank Perkreditan Rakyat) sangat dibutuhkan oleh masyarakat khususnya masyarakat kecil dan menengah. Walaupun kontribusinya terhadap volume kegiatan perbankan secara nasional kurang siqnifikan, namun dilihat dari luasnya transaksi yang dilakukan peranan lembaga keuangan mikro, sebagai mesin penggerak roda perekonomian di daerah-daerah khususnya daerah terpencil tidak diragukan.

Sejak dikeluarkannya Paket kebijaksanaan 28 Oktober 1988 yang lebih dikenal dengan Pakto 1988, peluang untuk membuka Bank Perkreditan Rakyat (BPR) yang semula tertutup sama sekali menjadi terbuka lebar. Selain dibuka BPR-BPR baru, lembaga-lembaga keuangan mikro lainnya yang telah tumbuh dan berkembang dari lingkungan masyarakat masih diperlukan, seperti Lembaga Dana Kredit Pedesaan dengan singkatan LDKP, LDP di Bali dan Badan Kredit Desa (BKD) keberadaanya masih tetap dibutuhkan. Dengan Peraturan Pemerintah telah ditetapkan persyaratan dan tatacara pemberian status lembaga-lembaga dimaksud untuk menjadi BPR. LDKP dengan UU perbankan 1992 diharapkan menjadi BPR dengan batas waktu selambat-lambatnya akhir Oktober 1997. Namun hanya sedikit yang dapat memenuhi persyaratan menjadi BPR, terutama untuk memenuhi persyaratan pemenuhan jumlah modal disetor yang ditetapkan minimal sebesar Rp. 50 juta. Bagi lembaga keuangan mikro yang belum berhasil menjadi BPR, tetap dapat melakukan kegiatan seperti semula, namun tidak termasuk sebagai bank.

Lima tahun sejak diluncurkannya Pakto 88 (Oktober 1988), jumlah BPR meningkat sangat drastis yaitu dari 432 menjadi 2.420 BPR pada akhir September 1999 atau meningkat $460 \%$. Pakto 88 telah mendorong BPR untuk tidak beroperasi di Ibukota negara, ibu kota provinsi dan kabupaten, melainkan di daerah-daerah pedesaan.

\footnotetext{
* Peneliti Kantor Bank Indonesia Surabaya
} 
Rata-rata BPR mempunyai asset Rp.1,3 milyar, dan apabila dikelompokkan dari nominal asset yang dimiliki maka diperoleh gambaran 441 BPR mempunyai asset Rp.1 milyar. Menyadari jumlah BPR yang begitu banyak telah menjadi beban yang berat bagi pengawasan Bank Indonesia, maka tambahan pembukaan BPR baru perlu dibatasi. Di samping tetap berupaya untuk meningkatkan BPR-BPR yang sudah ada menjadi lebih kuat dan sehat. Oleh karena itu sejak bulan Mei 1999 dikeluarkan peraturan baru yang mengatur jumlah minimal modal disetor BPR baru yang beroperasi di Jakarta dan sekitarnya minimal Rp.2 milyar untuk yang beroperasi di ibukota provinsi minimal Rp.1 milyar, dan untuk daerah lainnya minimal Rp.500 juta. Sampai saat ini, 14,7\% dari BPR mempunyai tingkat kesehatan Kurang Sehat, 28,1\% Tidak Sehat. Dengan prosentase 43\% (1040 BPR) dari jumlah BPR yang beroperasi di Indonesia mempunyai tingkat kesehatan non sehat adalah merupakan hal yang tidak menguntungkan dan perlu diupayakan bagaimana meningkatkan kesehatan mereka menjadi lebih baik.

Berkembangnya suatu lembaga keuangan mikro selain dari kondisi internal dan kinerja yang baik dari lembaga tersebut, juga tersedianya suasana yang kondusif yang memungkinkan lembaga keuangan berkembang secara wajar. Suasana kondusif ini merupakan perpaduan antara keadaan ekonomi, politik dan keamanan yang baik dan peraturan terkait yang menunjang.

Sejak tahun 1992 sejalan dengan diberlakukannya Undang-undang perbankan No.7 tahun 1992 tentang perbankan, mulai dikenal bank yang beroperasi berdasarkan prinsip syariah / Bank Perkreditan Rakyat Syariah (BPRS). Bank syariah sejak diberlakukannya UU tersebut mulai berkembang, hingga saat ini di seluruh Indonesia baru ada 2 bank umum syariah dan 3 bank umum yang membuka kantor cabang syariah serta 79 BPR syariah (6 BPR syariah beroperasi di Jawa Timur). Tingkat kesehatan BPR syariah yang beroperasi di Jatim per posisi Desember 1999, 4 BPRS yang mempunyai tingkat kesehatan Sehat, 1 BPRS Cukup Sehat, dan 1 BPRS Kurang Sehat.

Dalam baseline survey terdahulu (bulan Juni 2000 hasil kerja sama GTZ, BI, dan Perbarindo) BPRS dikeluarkan dari sampel karena sistem operasional BPRS berbeda dibandingkan dengan konvensional, di samping itu jumlah dan volume usahanya sangat kecil sedikit jika dibanding BPR konvensional. Dengan pertimbangan bahwa warna agama Islam dalam tatanan sosial penduduk Jawa Timur lebih menonjol dibandingkan penduduk propinsi lain, maka BPRS yang memiliki sistem spesifik dibandingkan BPR konvensional seperti tidak menggunakan sistem bunga (dhi bagi hasil), dan menghindari kegiatan spekulasi yang tidak produktif, maka survei mengenai BPRS menarik untuk dilakukan. Dari hasil survey ini diharapkan dapat menambah khasanah perbendaharaan pengetahuan kita dalam mengembangkan perbankan di Jatim khususnya dan BPR pada umumnya secara nasional. 


\subsection{Tujuan Survey}

Tujuan umum survey ini adalah untuk mengetahui keadaan kondisi internal, dan tingkat persaingan serta sistem pengawasan BPRS di wilayah kerja KBI surabaya. Informasi mengenai BPRS ini merupakan supplemen dalam pengawasan dan pembinaan BPR secara keseluruhan di Jawa Timur umumnya dan wilayah kerja KBI Surabaya pada khususnya.

\subsection{Metodologi Penelitian}

- Cakupan penelitian

Objek penelitian adalah BPRS yang beroperasi di Jawa Timur, dengan fokus pada kondisi internal, kinerjanya, tingkat persaingan serta pengawasan terhadap BPRS.

- Data

Data yang digunakan dalam survey ini berasal dari data sekunder dan primer. Data sekunder diperoleh dari literatur serta hasil baseline survey BPR Jatim, Bali dan NTB. Sedangkan data primer diperoleh langsung dari lapangan yakni dari semua BPRS yang ada di Jawa Timur (6 BPRS).

- Kuesioner

Konsep daftar pertanyaan BPRS dibuat oleh Bank Indonesia dengan memperhatikan daftar kuesioner yang telah dibuat bersama-sama dengan GTZ, Universitas Airlanggadalam rangka survai BPR terdahulu dan masukan dari Asbisindo.

Daftar pertanyaan yang digunakan untuk mengumpulkan data primer terdiri dari tiga macam yaitu:

1. Kuesioner I berhubungan dengan informasi umum BPRS

2. Kuesioner II berhubungan dengan informasi kualitatif BPRS

3. Kuesioner III berhubungan dengan data keuangan dan lainnya yang dapat diperoleh dari Bank Indonesia.

- Metode analisis

Dalam menganalisis data yang dikumpulkan, baik data primer maupun data sekunder, mencakup kondisi internal, persaingan, dan pengawasan BPR. Klasifikasi dan indikator yang digunakan oleh konsultan GTZ-Profi dalam menulis laporan survey BPR konvensional sebagian besar diterapkan pula pada BPR syariah. Klasifikasi utama yang digunakan dalam analisis ada dua yakni "kelas asset" dan "kelas kinerja kredit". seperti dalam tabel sbb : 


\begin{tabular}{|c|c|c|}
\hline Kelas & $\begin{array}{c}\text { Kelas Asset } \\
\text { Rp. }\end{array}$ & $\begin{array}{c}\text { Kelas Kinerja Kredit } \\
\text { Non Performing Loan (NPL) }\end{array}$ \\
\hline A & $<$ Rp.500 juta & $<5 \%$ \\
B & Rp.500 s.d Rp.1 milyar & 5 s.d $10 \%$ \\
C & Rp.1 s.d 5 milyar & 10 s.d 25\% \\
D & $>$ Rp.5 milyar & $>25 \%$ \\
\hline
\end{tabular}

\subsection{Organisasi Laporan}

- Bagian pertama mengambarkan mengenai latar belakang, tujuan dan metodologi survey dan organisasi laporan.

- Bagian kedua menyajikan hasil dari penelitian khususnya hal-hal yang berhubungan dengan kondisi keuangan, organisasi dan manajemen, kondisi persaingan, pengawasan, perlindungan simpanan dan asosiasii BPRS, termasuk pelatihan-pelatihan yang diharapkan untuk meningkatkan kualitas SDM BPR.

- Bagian akhir dari penulisan menyimpulkan temuan-temuan survey dan saran-saran.

Sebagai bahan perbandingan pada bagian lampiran laporan ini disertakan tabel-tabel yang memuat perbandingan angka-angka antara BPR dengan sistem syariah, (hasil survey BPR syariah Jatim) dengan BPR konvensional (hasil survey BPR konvensional di Jatim, Bali, NTB).

\section{Sampel Survey}

\subsection{Lokasi, Tipe BPR dan Jangka Waktu Operasi}

Di wilayah provinsi Jawa Timur terdapat 6 BPR syariah (BPRS) dan semuanya tergolong BPR gaya baru (didirikan setelah diberlakukannya Undang Undang No.7 tahun 1992) yang memungkinkan bank beroperasi dengan prinsip bagi hasil, dengan badan hukum Perseroan Terbatas (PT).

Jangka waktu operasi BPRS sampai saat ini rata-rata 4 tahun, hal ini dapat dimaklumi karena sistem syariah (sebelumnya dengan istilah bagi hasil) merupakan sistem operasional perbankan yang spesifik, yang secara yuridis baru dimungkinkan sejak berlaku undangundang No.7 tahun 1992. Sebagian besar jangka waktu operasional BPRS berkisar antara 5 - 9 tahun, sedangkan satu BPRS merupakan hasil konversi dari BPR konvensional. (Tabel II.1). 


\subsection{Klasifikasi Asset}

Jumlah asset BPRS di Jawa Timur per Desember 1999 rata-rata adalah Rp.1.240 juta, sedangkan BPR konvensional di Jawa Timur jumlah assetnya rata-rata sebesar Rp.1.726 juta (lihat tabel II.1). Jumlah asset rata-rata BPRS yang masih rendah disebabkan jangka waktu beroperasi yang relatif baru dan BPR yang beroperasi dengan sistem syariah belum begitu dikenal dikalangan masyakat luas. Jangka waktu beroperasi BPR ternyata sangat mempengaruhi besarnya jumlah asset suatu BPRS, hal ini tergambar pada jawaban para direktur BPRS mengenai tingkat persaingan yang akan diuraikan pada bahasan persaingan.

Tabel II.1 :

Klasifikasi BPR Syariah Di Jawa Timur

\begin{tabular}{|c|c|}
\hline & B P R S \\
\hline Jml BPRS & 6 \\
\hline \multicolumn{2}{|l|}{ Tipe BPRS } \\
\hline$\%$ BPR Sebelum Pakto 88 & 100,0 \\
\hline$\%$ BPR Setelah Pakto 88 & 0,0 \\
\hline$\%$ BPR Ex-LDKP & 0,0 \\
\hline \multicolumn{2}{|l|}{ Status Hukum } \\
\hline$\overline{\% \text { Perusahaan Terbatas }}$ & 100,0 \\
\hline$\%$ Perusahaan Daerah & 0,0 \\
\hline$\%$ Koperasi & 0,0 \\
\hline \multicolumn{2}{|l|}{ Tahun Beroperasi } \\
\hline Rata2 beroperasi & 4,0 \\
\hline$\%$ BPR $1-3$ tahun & 17,0 \\
\hline$\%$ BPR 5 -9 tahun & 83,0 \\
\hline$\%$ BPR 10 thn dan lebih & 0,0 \\
\hline \multicolumn{2}{|l|}{ Asset $^{1}$} \\
\hline$\overline{\text { Rata2 }}$ (Rp. milyar) & 1,2 \\
\hline$\%$ BPR $<$ Rp.500 juta & 50,0 \\
\hline$\%$ BPR Rp.500 - < 1 Milyar & 0,0 \\
\hline \% BPR Rp.1 - Rp.5 Milyar & 50,0 \\
\hline$\%$ BPR > Rp. 5 Milyar & 0,0 \\
\hline \multicolumn{2}{|l|}{$\%$ Portofolio kredit/Asset } \\
\hline Prosentase & 67,0 \\
\hline$\% \mathrm{BPR}<60 \%$ & 50,0 \\
\hline$\% \mathrm{BPR}>85 \%$ & 17,0 \\
\hline \multicolumn{2}{|l|}{ Rata-rata outstanding kredit } \\
\hline Rata2 (Rp. juta) & 1,6 \\
\hline$\% \mathrm{BPR}<\mathrm{Rp} 1$ juta & 33,0 \\
\hline$\%$ BPR > Rp. 2 juta & 17,0 \\
\hline \multicolumn{2}{|l|}{ \% Kredit Non Lancar } \\
\hline Rata2 $(\%)$ & 18,0 \\
\hline$\% \mathrm{BPR}<10 \%$ & 50,0 \\
\hline$\% \mathrm{BPR}>25 \%$ & 17,0 \\
\hline
\end{tabular}

1 Seperti yang dijelaskan dalam BAB I (1.3) Kelas asset dibagi menjadi empat yakni; kelas A dgn asset < Rp.500 jt; kelas B dgn asset Rp.500 juta - Rp.1 milyar; Kelas C dgn asset Rp.1 - 5 milyar; kelas D dgn asset > 5 milyar. 
Asset BPRS terutama ditanamkan dalam portofolio pembiayaan (atau kredit pada BPR konvensional), yang mencapai porsi $67 \%$ dari total asset. Portofolio pembiayaan BPRS di bawah $50 \%$ dan yang di atas $85 \%$, masing-masing ada satu BPRS, khusus yang di bawah $50 \%$ adalah BPRS yang baru beroperasi satu tahun.

Apabila diambil secara rata-rata dari 6 BPRS, maka porsi pembiayaan terhadap total asset sebesar $64 \%$. Sementara itu apabila dilihat dari "kinerja kredit", rata-rata prosentase kredit non lancar BPRS adalah 18\% (lihat tabel II.2). Perbedaan NPL yang besar pada masingmasing BPRS menunjukkan perbedaan pola manajemen pada masing-masing BPRS. Rendahnya portofolio NPL juga dapat mengindikasikan bahwa BPRS yang over-liquid disebabkan sulitnya mendapatkan debitur yang layak, di lain pihak tingginya penempatan pembiayaan menyebabkan penyediaan modal, likuiditas dan resiko pembiayaan meningkat.

Table II.2 :

Variasi Asset, Portofolio Pembiayaan (kredit) dan

Kualitas Aktiva Produktif

\begin{tabular}{|l|c|}
\hline & $\begin{array}{c}\text { B P R } \\
\text { Syariah }\end{array}$ \\
\hline Jumlah BPR & 6 \\
Jumlah Kantor & 10 \\
& \\
Asset ${ }^{*}$ ) & 1.240 \\
Rata-rata Asset (Rp. Jutaan) & 50,0 \\
$\%$ BPR < Rp. 1 Milyar & - \\
$\%$ BPR > Rp. 5 Milyar & - \\
$\%$ BPR-LDKP < Rp.1 Milyar & \\
Portofolio Kredit/Asset *) & 64 \\
Rata-rata \% & 17 \\
$\%$ BPR < 50\% & 17 \\
BPR > 85\% & 67 \\
Rata2 kredit/rata2 asset (\%) & \\
Kredit Non performing ${ }^{*}{ }^{2}$ & 18 \\
$\%$ Rata-rata & 50 \\
$\%$ BPR < 10\% $>25 \%$ & 17 \\
\hline
\end{tabular}

Keterangan :

*) Dari rata-rata masing-masing individu BPRS

2 Seperti yang dijelaskan dalam BAB I (1.3) Kelas kinerja kredit dibagi menjadi empat yakni; kelas A dgn NPL < Rp.5\%; kelas B dgn NPL 5\% - 10\%; Kelas C dgn NPL 10\%-25\%; kelas D dgn NPL > $25 \%$ 


\section{Kondisi Internal}

Pembahasan dalam bab ini dibagi menjadi dua bagian, yakni bagian pertama membahas kondisi keuangan yang menguraikan mengenai struktur neraca dan laba rugi BPRS, berdasarkan besarnya asset dan kinerja perkreditannya. Dalam bagian kedua akan dibahas hal-hal yang berhubungan dengan organisasi dan manajemen, termasuk pelatihanpelatihan yang diharapkan oleh BPRS dalam rangka meningkatkan kualitas manajemen BPRS.

\subsection{Kondisi Keuangan}

\subsubsection{Struktur Neraca dan Rugi Laba}

Dalam membahas kondisi keuangan BPRS akan dianalisa struktur asset, hutang, pendapatan berikut struktur biaya yang didasarkan pada neraca dan laporan laba rugi BPRS (Desember 1999). Istilah-istilah yang digunakan dalam pembahasan kondisi keuangan menggunakan istilah-istilah seperti dalam pos laporan bulanan BPR.

\subsubsection{Analisis Struktur Neraca}

Analisis terhadap neraca dimungkinkan dapat terdeteksi masalah- masalah manajemen keuangan dan sumber-sumber inefisiensi pada BPRS. Tabel III.1 dan III.2 memperlihatkan kombinasi neraca baik dari kelas asset maupun kelas kinerja kedit, dengan catatan angka prosentase pada tabel tidak menyertakan Pembentukan Penyisihan Penghapusan Aktiva Produktif (PPAP).

Pada tabel III.1 dapat diketahui bahwa struktur asset BPRS sebagian besar terdiri dari portofolio pembiayaan sebesar $67 \%$, penempatan pada bank lain sebesar $26 \%$, sedangkan pembentukan Penyisihan Penghapusan Aktiva Produktif masih belum memenuhi ketentuan.

Apabila kita lihat dari kelas asset ternyata dari 6 BPRS di Jatim termasuk dalam kelas A (kurang dari Rp.500 juta) sebanyak 3 BPRS dan kelas C (Rp.1 milyar s.d Rp.5 milyar) sebanyak 3 BPRS.

BPRS kelas asset C sebagian besar (70\%) assetnya ditempatkan dalam bentuk pembiayaan, sedangkan BPRS kelas asset A hanya sebesar 51\% dari total asset. BPRS kelas asset $\mathrm{C}$ menempatkan dananya pada bank lain (ABA) sebesar $28 \%$ dari total asset dan BPRS kelas asset A sebesar 10\%.

Aktiva tetap bersih (aktiva tetap minus penyusutan) menyumbang kurang dari 5\% dari total asset ada pada 4 BPRS, sedangkan 2 BPRS yang lain menempatkan lebih dari 
Tabel III.1

Neraca Gabungan berdasarkan Kelas Asset

(dlm Rp. Juta)

\begin{tabular}{|c|c|c|c|}
\hline \multirow{2}{*}{ Uraian } & \multicolumn{2}{|c|}{ Asset Class } & \multirow{2}{*}{$\begin{array}{c}\text { Total } \\
\text { BPR Syariah }\end{array}$} \\
\hline & $\mathbf{A}$ & $\mathrm{C}$ & \\
\hline Jml BPRS & 3 & 3 & 6 \\
\hline ASSETS & & & \\
\hline Kas & 25,9 & 37,9 & 63,8 \\
\hline$A B A / B I$ & 93,5 & $1.813,4$ & $1.906,9$ \\
\hline Portofolio kredit & 488,3 & $4.526,0$ & $5.014,3$ \\
\hline Lancar $(\%)$ & 83,7 & 92,2 & 88,0 \\
\hline Kurang Lancar (\%) & 4,4 & 3,2 & 3,8 \\
\hline Diragukan $(\%)$ & 11,3 & 4,4 & 7,9 \\
\hline Macet $(\%)$ & 0,7 & 0,2 & 0,5 \\
\hline (-) PPAP & $(9,3)$ & $(152,5)$ & $(161,8)$ \\
\hline Asset Tetap & 151,4 & 180,2 & 331,6 \\
\hline (-) Penyusutan & $(30,1)$ & $(100,4)$ & $(130,6)$ \\
\hline Asset lainnya & 245,7 & 170,0 & 415,8 \\
\hline TOTAL ASSETS & 965,4 & $6.474,6$ & $7.439,9$ \\
\hline \multicolumn{4}{|l|}{ HUTANG/LIABILITIES } \\
\hline Hutang Lancar & 2,6 & 25,1 & 27,6 \\
\hline Tabungan & 260,2 & $1.869,2$ & $2.129,4$ \\
\hline Deposito & $\overline{116,8}$ & $1.830,4$ & $1.947,2$ \\
\hline ABP/BI/kredit & 12,1 & $1.127,0$ & $1.139,0$ \\
\hline Kewajiban lainnya & 6,2 & 57,4 & 63,6 \\
\hline \multicolumn{4}{|l|}{ EQUITY } \\
\hline$\overline{\text { Modal disetor }}$ & 619,5 & 921,8 & $1.541,3$ \\
\hline Modal Lainnya & 16,8 & 98,6 & 115,4 \\
\hline Cadangan & 0,0 & 185,0 & 185,0 \\
\hline \multicolumn{4}{|l|}{$L A B A / R U G I$} \\
\hline Akumulasi & $(50,8)$ & 21,1 & $(29,7)$ \\
\hline Thn berjalan & $(18,0)$ & 339,1 & 321,1 \\
\hline TOTAL PASIVA & 965,4 & $6.474,6$ & $7.439,9$ \\
\hline Kas/Asset & $3 \%$ & $1 \%$ & $1 \%$ \\
\hline$A B A \mathcal{E} B I /$ Asset & $10 \%$ & $28 \%$ & $26 \%$ \\
\hline Kredit/Asset & $51 \%$ & $70 \%$ & $67 \%$ \\
\hline Akt.tetap/Asset & $13 \%$ & $1 \%$ & $3 \%$ \\
\hline Tab/Passiva & $27 \%$ & $29 \%$ & $29 \%$ \\
\hline Dep/Passiva & $12 \%$ & $28 \%$ & $26 \%$ \\
\hline Mdldstr/Pass & $64 \%$ & $14 \%$ & $21 \%$ \\
\hline LR/Passiva & $-7 \%$ & $6 \%$ & $4 \%$ \\
\hline
\end{tabular}

Keterangan:

A: $<$ Rp. 500 juta, C: Rp. $1 \mathrm{M}$ - Rp. $5 \mathrm{M}$ 
10\%. Aktiva tetap bersih pada BPRS kelas A lebih tinggi (13\%) dibandingkan dengan BPRS kelas C $(1,2 \%)$, hal ini disebabkan BPRS kelas A relatif baru didirikan.

Apabila dilihat dari sisi passiva struktur liabilities (kewajiban) BPRS tidak terlalu didominasi oleh dana dari pihak ketiga. Deposito menyumbang sebesar 26\% dari seluruh kewajiban dan equity (passiva) dan tabungan menyumbang sekitar $29 \%{ }^{3}$. Hal ini mengindikasikan bahwa masyarakat belum banyak tahu tentang praktek perbankan syariah yang menerapkan bagi hasil. Masyarakat belum terdorong untuk menyimpan uangnya pada BPRS, karena lebih tertarik dan terbiasa kepada BPR konvensional yang menawarkan sistem bunga. Nampaknya BPR dengan sistem syariah masih harus lebih gencar melakukan promosi agar lebih dikenal masyarakat sebagai salah satu alternatif penyimpan uang.

Apabila dilihat dari kelas asset, sumber dana BPRS kelas C terdiri dari deposito sebesar $28 \%$, tabungan sebesar $29 \%$ dan modal disetor sebesar $14 \%$. BPRS kelas asset $\mathrm{A}^{2)}$ sumber dananya lebih banyak dari modal disetor dengan sumbangan tabungan sebesar $27 \%$, deposito sebesar $12 \%$ dan modal disetor sebesar $64 \%$. Hal ini mengindikasikan bahwa BPRS kelas asset A masih mengalami kesulitan menghimpun dana dari masyarakat karena masih relatif baru.

Apabila dilihat dari kinerja kredit (tabel III.2) ternyata tidak ada pola hubungan yang jelas antara struktur asset BPRS dengan kinerja kredit. Struktur asset (aktiva) pada BPRS berkinerja kredit paling baik (kelas A) dengan BPRS berkinerja baik (B) berbeda secara signifikan. BPRS kelas kinerja kredit A menginvestasikan sebesar $82 \%$ dari total assetnya dalam bentuk pembiayaan dan sebesar $9 \%$ dalam bentuk penempatan pada bank lain, sedangkan BPRS kelas kinerja kredit B penempatan dalam pembiayaan mencapai $71 \%$ dan dalam bentuk penempatan pada bank lain sebesar $25 \%$.

Pada BPRS kelas kinerja kredit D menempatkan dananya dalam bentuk pembiayaan sebesar 50\% dan dalam bentuk antar bank sebesar 13\%. Sebagian besar BPRS pada kelas kinerja kredit $\mathrm{C}$ adalah BPRS besar, menempatkan dananya dalam bentuk pembiayaan sebesar $56 \%$ dan dalam bentuk penempatan antar bank sebesar $38 \%$.

BPRS yang portofolio kreditnya kurang dari 60\% diindikasikan bahwa BPRS yang bersangkutan sulit menemukan peminjam yang layak dan tingkat resiko yang tinggi menyebabkan portofolio pembiayaan rendah karena mereka sangat berhati-hati dalam menyalurkan pembiayaan. Yang masuk dalam kriteria ini adalah BPRS kelas kinerja kredit $\mathrm{C}$ dan D. Dari klasifikasi kinerja kredit terlihat bahwa semakin besar jumlah pembiayaan semakin kecil NPL BPRS yang bersangkutan.

3) Pada BPR konvensional porsi tabungan sebesar 20\% dan porsi deposito $56 \%$ 
Tabel III.2

Neraca Gabungan berdasarkan kinerja kredit

(dlm Juta)

\begin{tabular}{|c|c|c|c|c|c|}
\hline \multirow{2}{*}{ I t e m s } & \multicolumn{4}{|c|}{ Kelas kinerja kredit } & \multirow{2}{*}{$\begin{array}{l}\text { Total } \\
\text { BPRS. }\end{array}$} \\
\hline & $\begin{array}{c}\text { A } \\
\text { BPRS. }\end{array}$ & $\begin{array}{c}\text { B } \\
\text { BPRS. }\end{array}$ & $\begin{array}{c}\text { C } \\
\text { BPRS. }\end{array}$ & $\begin{array}{c}\text { D } \\
\text { BPRS. }\end{array}$ & \\
\hline $\begin{array}{l}J m l \text { BPRS } \\
\text { ASSETS }\end{array}$ & 2 & 1 & 2 & 1 & 6 \\
\hline$\overline{\text { Kas }}$ & 9,4 & 20,2 & 23,4 & 10,6 & 63,8 \\
\hline$A B A / B I$ & 210,5 & 373,6 & $1.307,8$ & 15,0 & $1.906,9$ \\
\hline Fotofolio kredit & $1.995,7$ & $1.048,5$ & $1.913,6$ & 56,4 & $5.014,3$ \\
\hline Lancar (\%) & 99,8 & 93,5 & 83,3 & 32,1 & 77,2 \\
\hline $\mathrm{KL}(\%)$ & 0,2 & 4,0 & 5,9 & 11,0 & 5,3 \\
\hline $\mathrm{D}(\%)$ & 0,0 & 2,1 & 10,7 & 51,3 & 16,0 \\
\hline Macet (\%) & 0,0 & 0,4 & 0,3 & 5,7 & 1,6 \\
\hline (-) PPAP & $(112,2)$ & $(16,3)$ & $(32,7)$ & $(0,6)$ & $(161,8)$ \\
\hline Asset Tetap & 115,0 & 37,3 & 157,2 & 22,1 & 331,6 \\
\hline (-) Penyusutn & $(10,4)$ & $(16,0)$ & $(93,7)$ & $(10,5)$ & $(130,6)$ \\
\hline Asset lainnya & 219,5 & 19,4 & 158,0 & 18,8 & 415,8 \\
\hline TTL ASSETS & $2.427,5$ & $1.466,8$ & $3.433,8$ & 111,9 & $7.439,9$ \\
\hline LIABILITIES & & & & & \\
\hline Htg Lancar & 6,5 & 0,7 & 20,5 & 0,0 & 27,6 \\
\hline Tabungan & 895,9 & 207,3 & 975,3 & 50,9 & $2.129,4$ \\
\hline Deposito & 501,8 & 343,0 & $1.101,7$ & 0,8 & $1.947,2$ \\
\hline ABA/BI/loans & 341,3 & 685,7 & 100,0 & 12,1 & $1.139,0$ \\
\hline Kewajiban lainnya & 29,9 & 21,3 & 10,3 & 2,1 & 63,6 \\
\hline EQUITY & & & & & \\
\hline Modal disetor & 577,9 & 155,0 & 714,6 & 93,7 & $1.541,3$ \\
\hline Modal Lainnya & 0,0 & 0,0 & 113,6 & 1,8 & 115,4 \\
\hline Cadangan & 25,7 & 0,0 & 159,3 & 0,0 & 185,0 \\
\hline$L A B A / R U G I$ & & & & & \\
\hline Akumulasi & 0,0 & 21,1 & $(0,3)$ & $(50,5)$ & $(29,7)$ \\
\hline Thn berjalan & 48,6 & 32,8 & 238,8 & 0,9 & 321,1 \\
\hline LIABILITIES & & & & & \\
\hline \& EQUITY & $2.427,5$ & $1.466,8$ & $3.433,8$ & 111,9 & $7.439,9$ \\
\hline Kas/Asset & $0 \%$ & $1 \%$ & $1 \%$ & $10 \%$ & $1 \%$ \\
\hline ABAEBI/Asset & $9 \%$ & $25 \%$ & $38 \%$ & $13 \%$ & $26 \%$ \\
\hline Kredit/Asset & $82 \%$ & $71 \%$ & $56 \%$ & $50 \%$ & $67 \%$ \\
\hline Akt.tetap/Asset & $4 \%$ & $1 \%$ & $2 \%$ & $10 \%$ & $3 \%$ \\
\hline ABP/Passiva & $14 \%$ & $47 \%$ & $3 \%$ & $11 \%$ & $15 \%$ \\
\hline Tab/Passiva & $37 \%$ & $14 \%$ & $28 \%$ & $46 \%$ & $29 \%$ \\
\hline Dep/Passiva & $21 \%$ & $23 \%$ & $32 \%$ & $1 \%$ & $26 \%$ \\
\hline Mdl dstr/Pass & $24 \%$ & $11 \%$ & $21 \%$ & $84 \%$ & $21 \%$ \\
\hline LR/Passiva & $3 \%$ & $4 \%$ & $7 \%$ & $-108 \%$ & $3,9 \%$ \\
\hline
\end{tabular}

Kredit non lancar: A: $<5 \%$, B: $5-<10 \%$, C: $10-25 \%$, D: $>25 \%$

Dari sisi passiva, sumber dana BPRS dengan kinerja paling baik (kelas kinerja kredit A) antara deposito dan modal disetor relatif berimbang masing-masing $21 \%$ berbanding 24\%, sedangkan BPRS dengan kinerja paling buruk (kelas kinerja kredit D) sumber pendanaan yang berasal dari deposito tidak berperan sama sekali (hanya 1\%), dan hampir seluruhnya berasal dari modal disetor $(84 \%)$. 
BPRS dengan kinerja baik memperoleh laba 3\% dari total asset (ROA) dan BPRS dengan kinerja buruk ROAnya (-) 44\%. Struktur sumber dana pada BPRS kelas kinerja B adalah $23 \%$ deposito, $14 \%$ tabungan, $11 \%$ equity, dan $4 \%$ laba. Struktur sumber dana BPRS kelas kinerja C adalah $32 \%$ deposito, 28\% tabungan, $21 \%$ equity, dan $7 \%$ laba.

Seperti juga kecenderungan pada sisi aktiva bahwa semakin besar jumlah pembiayaan semakin kecil NPLnya, maka pada sisi passiva terlihat semakin besar dana pihak ketiga, maka semakin baik kondisi NPL BPRS yang bersangkutan. Keadaan tersebut mengambarkan bahwa semakin besar total aktiva bank berarti bank tersebut semakin dipercaya oleh masyarakat karena kinerja bank tersebut baik.

\section{Gambar 1}

Struktur Neraca Rata-Rata BPR Syariah

\begin{tabular}{|c|c|c|c|c|c|c|c|}
\hline \multicolumn{4}{|c|}{ Kelas Asset A } & \multicolumn{4}{|c|}{ Kelas Kinerja Kredit A } \\
\hline Pos Nrc & Nilai & Pos Nrc & Nilai & Pos Nrc & Nilai & Pos Nrc & Nilai \\
\hline Kas & $4 \%$ & $\mathrm{~Tb} \& \mathrm{Dp}$ & $40 \%$ & Kas & $1 \%$ & $\mathrm{~Tb} \& \mathrm{Dp}$ & $52 \%$ \\
\hline $\mathrm{ABA}$ & $11 \%$ & $\mathrm{ABP} / \mathrm{BI}$ & $4 \%$ & $\mathrm{ABA}$ & $8 \%$ & $\mathrm{ABP} / \mathrm{BI}$ & $9 \%$ \\
\hline Pembiayaan & $54 \%$ & Equity & $37 \%$ & Pembiayaan & $62 \%$ & Equity & $38 \%$ \\
\hline & & Profit & $-16,0 \%$ & & & Profit & $5 \% *)$ \\
\hline \multicolumn{4}{|c|}{ Kelas Asset C } & \multicolumn{4}{|c|}{ Kelas Kinerja Kredit B } \\
\hline Pos Nrc & Nilai & Pos Nrc & Nilai & Pos Nrc & Nilai & Pos Nrc & Nilai \\
\hline Kas & $1 \%$ & Tab \& Dep & $54 \%$ & Kas & $1 \%$ & Tab \& Dep & $38 \%$ \\
\hline $\mathrm{ABA}$ & $25 \%$ & $\mathrm{ABP} / \mathrm{BI}$ & $23 \%$ & $\mathrm{ABA}$ & $25 \%$ & $\mathrm{ABP} / \mathrm{BI}$ & $47 \%$ \\
\hline \multirow[t]{2}{*}{ Pembiayaan } & $73 \%$ & Equity & $22 \%$ & Pembiayaan & $71 \%$ & Equity & $14 \%$ \\
\hline & & Profit & $5 \%$ & & & Profit & $4 \%$ \\
\hline & & & & \multicolumn{4}{|c|}{ Kelas Kinerja Kredit C } \\
\hline & & & & Pos Nrc & Nilai & Pos Nrc & Nilai \\
\hline & & & & Kas & $2 \%$ & Tab \& Dep & $49 \%$ \\
\hline & & & & $\mathrm{ABA}$ & $26 \%$ & $\mathrm{ABP} / \mathrm{BI}$ & $2 \%$ \\
\hline & & & & Pembiayaan & $68 \%$ & Equity & $23 \%$ \\
\hline & & & & & & Profit & $6 \%$ \\
\hline \multicolumn{4}{|c|}{ BPRS di Jatim } & \multicolumn{4}{|c|}{ Kelas Kinerja Kredit D } \\
\hline Pos Nrc & Nilai & Pos Nrc & Nilai & Pos Nrc & Nilai & Pos Nrc & Nilai \\
\hline Kas & $3 \%$ & Tab \& Dep & $47 \%$ & Kas & $10 \%$ & Tab \& Dep & $46 \%$ \\
\hline ABA & $18 \%$ & $\mathrm{ABP} / \mathrm{BI}$ & $13 \%$ & ABA & $13 \%$ & $\mathrm{ABP} / \mathrm{BI}$ & $11 \%$ \\
\hline Pembiayaan & $64 \%$ & Equity & $30 \%$ & Pembiayaan & $50 \%$ & Equity & $41 \%$ \\
\hline & & Profit & $3 \% * *)$ & & & Profit & $-44 \%$ \\
\hline
\end{tabular}


Gambar 1 menyajikan struktur neraca berdasarkan "kelas asset" dan "kinerja kredit". Untuk menghindari hilangnya informasi jika neraca digabungkan, prosentase tidak didasarkan pada angka absolut tetapi diwakili oleh porsi rata-rata setiap neraca BPRS.

Struktur asset BPRS di Jatim secara rata-rata di sisi aktiva terdiri dari; $64 \%$ dalam bentuk pembiayaan, $18 \%$ dalam bentuk antar bank aktiva, dan 3\% dalam bentuk tunai dan selebihnya berupa aktiva tetap dan asset lainnya. Sedangkan dari sisi pasiva terdiri dari tabungan dan deposito sebesar $47 \%$, pinjaman antar bank sebesar $13 \%$ dan equity $30 \%$, serta laba ditahan sebesar 3\%.

Sebagaimana terlihat pada gambar 1 struktur neraca berdasarkan kelas asset berbeda dengan kelas kinerja kredit. Dilihat dari kelas asset struktur neraca rata-rata tercermin semakin besar asset BPRS semakin besar porsi portofolio pembiayaan dan ABA, begitu juga ketergantungnya pada dana pihak ketiga dan ABP/BI, namun porsi equity menurun. Bila diamati melalui kelas kinerja kredit pada BPRS tercermin bahwa semakin baik kinerja kreditnya maka semakin kecil prosentase penempatan dana antar bank. BPRS dengan kinerja paling baik (A) prosentase rata-rata penempatan dana antar banknya sebesar $8 \%$, untuk kelas B dan C porsinya di atas $20 \%$. Begitu juga uang tunai, semakin baik kinerja kreditnya semakin kecil porsi uang tunainya. Seluruh BPRS kecuali kelas kredit D porsi pembiayaan rata-rata di atas $60 \%$.

Apabila dilihat dari sisi passiva yang paling menonjol adalah dana pihak ketiga $(46 \%$ s.d 52\%) dan equity ( $23 \%$ s.d $41 \%$ ), kecuali BPRS kelas B dimana yang paling besar justru pinjaman dari BI yaitu sebesar $47 \%$.

BPRS dengan kelas kinerja paling buruk menderita kerugian $-44 \%$ dari total passiva, sedangkan yang lain mengalami keuntungan antara $4 \%$ s.d $6 \%$.

\subsubsection{Analisis Struktur Laba Rugi}

Analisis terhadap laporan laba rugi dilakukan dengan cara melihat aspek-aspek sumber pendapatan dan pengeluaran biaya. Pendapatan BPRS terutama berasal dari pendapatan kegiatan pembiayaan yang disalurkan yakni $88 \%$ dari total pendapatan. Biaya operasional mencapai $99 \%$, dan biaya non operasional sebesar $1 \%$ masingmasing dari total biaya. Biaya paling banyak yang dikeluarkan oleh BPRS adalah biaya penghimpunan dana yakni sebesar $28 \%$ dari total biaya. Tabel III.3 dan tabel III.4 menggambarkan kombinasi laporan laba rugi berdasarkan kelas asset dan kinerja kredit.

Apabila dilihat dari kelas asset BPRS, maka dapat digambarkan sebagai berikut (lihat tabel III.3): 
Tabel III.3 :

Laporan Laba Rugi berdasarkan Kelas Asset

\begin{tabular}{|c|c|c|c|}
\hline \multirow[b]{2}{*}{ Urai a n } & \multicolumn{2}{|c|}{ Asset Class } & \multirow{2}{*}{$\begin{array}{r}\text { Total } \\
\text { BPR Sy }\end{array}$} \\
\hline & $\begin{array}{c}\text { A } \\
\text { BPR Sy }\end{array}$ & $\begin{array}{c}\text { C } \\
\text { BPR Sy }\end{array}$ & \\
\hline Jumlah BPR & 3 & 3 & 6 \\
\hline INCOME & & & \\
\hline Bunga bank & 26,3 & 125,9 & 152,2 \\
\hline Pdptn kredit & 99,0 & $1.418,2$ & $1.517,3$ \\
\hline Pdptn oprs. Lainnya & 0,8 & 17,2 & 18,0 \\
\hline Pdptn oprs. total & 130,8 & $1.561,4$ & 1692, \\
\hline Pdptn non oprs. & 22,9 & 7,8 & 30,7 \\
\hline TOTAL INCOME & 153,7 & $1.569,2$ & $1.722,9$ \\
\hline BIAYA & & & \\
\hline Bga u/ BI/bank lain & 0,0 & 212,6 & 212,6 \\
\hline Bunga kpd nasabah & 25,0 & 363,1 & 388,1 \\
\hline Biaya pegawai & 71,8 & 298,5 & 370,3 \\
\hline Penghapusan & 30,5 & 160,1 & 190,5 \\
\hline Biaya oprs. Lainnya & 32,2 & 171,3 & 203,5 \\
\hline Biaya oprs. Total & 159,4 & $1.205,6$ & $1.365,1$ \\
\hline Biaya non oprsl. & 10,2 & 4,6 & 14,8 \\
\hline TOTAL BIAYA & 169,7 & $1.210,2$ & 1.379 .8 \\
\hline LABA/RUGI & & & \\
\hline Sblm pajak & $(16,0)$ & 358,9 & 34,0 \\
\hline Setelah pajak & $(18,0)$ & 355,5 & 325,9 \\
\hline Bunga bank & $18 \%$ & $8 \%$ & $9 \%$ \\
\hline Pedapatan kredit & $66 \%$ & $90 \%$ & $88 \%$ \\
\hline Pendaptan oprs lain & $1 \%$ & $1 \%$ & $1 \%$ \\
\hline Pdptn non Opsr. & $15 \%$ & $0 \%$ & $2 \%$ \\
\hline Bunga ke BI/Bank & $0 \%$ & $18 \%$ & $15 \%$ \\
\hline Bunga kpd nasabah & $15 \%$ & $30 \%$ & $28 \%$ \\
\hline Bya. Pegawai & $42 \%$ & $25 \%$ & $27 \%$ \\
\hline Penghapusan & $18 \%$ & $13 \%$ & $14 \%$ \\
\hline Biaya oprs. Lainnya & $19 \%$ & $14 \%$ & $15 \%$ \\
\hline Total Biaya & $94 \%$ & $100 \%$ & $99 \%$ \\
\hline Biaya Non Oprs. & $6 \%$ & $0 \%$ & $1 \%$ \\
\hline
\end{tabular}

A: < Rp. 500 juta, C: Rp. 1M - Rp.5 M,

a. Pendapatan dari pembiayaan (kredit) BPRS kelas asset A sebesar $66 \%$ dari total pendapatannya, sedangkan pendapatan dari penempatan dana antar bank $18 \%$. Sementara itu, pendapatan dari pembiayaan (kredit) BPRS kelas asset C sebesar 90\% dari total pendapatannya, sedangkan pendapatan dari penempatan dana antar bank sebesar $8 \%$. 
Tabel III.4 :

Laporan Laba Rugi berdasarkan Kelas Kinerja Kredit

\begin{tabular}{|c|c|c|c|c|c|}
\hline \multirow{2}{*}{ Urai a n } & \multicolumn{4}{|c|}{ Kinerja kredit } & \multirow{2}{*}{ Total } \\
\hline & A & B & C & D & \\
\hline Jumlah BPR & 2 & 1 & 2 & 1 & 6 \\
\hline \multicolumn{6}{|l|}{ PENDAPATAN } \\
\hline Bunga bank & 15,1 & 5,0 & 132,1 & 0,0 & 152,2 \\
\hline Pdptn kredit & 570,5 & 255,9 & 677,3 & 13,6 & $.517,3$ \\
\hline Pdptn opsl lain & 2,0 & 15,3 & 0,7 & 0,0 & 18,0 \\
\hline Ttl pdptn oprsl & 592,3 & 276,2 & 810,1 & 13,6 & $.692,2$ \\
\hline Ttl pdpt non oprs & 0,0 & 0,0 & 12,5 & 18,3 & 30,7 \\
\hline PENDAPATAN TOTAL & 592,3 & 276,2 & 822,6 & 31,8 & $1.722,9$ \\
\hline \multicolumn{6}{|l|}{ BIAYA } \\
\hline Bunga kpd BI/bank & 85,0 & 78,7 & 49,0 & 0,0 & 212,6 \\
\hline Bunga kpd Nasabah & 156,2 & 54,5 & 174,7 & 2,6 & 388,1 \\
\hline Biaya pegawai & 104,9 & 49,2 & 199,0 & 17,2 & 370,3 \\
\hline Penghapusan & 103,2 & 20,6 & 61,7 & 5,1 & 190,5 \\
\hline Bya oprsl lainnya & 74,9 & 37,0 & 87,1 & 4,5 & 203,5 \\
\hline Total biaya Operasional & 524,2 & 240,0 & 571,5 & 29,4 & $1.365,1$ \\
\hline Biaya non Operasional & 3,0 & 0,0 & 10,3 & 1,5 & 14,8 \\
\hline BIAYA TOTAL & 527,2 & 240,0 & 581,8 & 30,9 & $1.379,9$ \\
\hline \multicolumn{6}{|l|}{ LABA/RUGI } \\
\hline Sebelum pajak & 65,0 & 36,2 & 240,8 & 0,9 & 343,0 \\
\hline Setelah pajak & 65,0 & 21,1 & 238,8 & 0,9 & 325,9 \\
\hline Bunga bank & $3 \%$ & $2 \%$ & $16 \%$ & $0 \%$ & $9 \%$ \\
\hline Pedapatan kredit & $97 \%$ & $93 \%$ & $82 \%$ & $43 \%$ & $88 \%$ \\
\hline Pendaptan oprs lain & $0 \%$ & $6 \%$ & $0 \%$ & $0 \%$ & $1 \%$ \\
\hline Pdptn non Opsr. & $0 \%$ & $0 \%$ & $2 \%$ & $57 \%$ & $2 \%$ \\
\hline Bunga ke BI/Bank & $16 \%$ & $33 \%$ & $8 \%$ & $0 \%$ & $15 \%$ \\
\hline Bunga kpd nasabah & $30 \%$ & $23 \%$ & $30 \%$ & $8 \%$ & $28 \%$ \\
\hline Bya. Pegawai & $20 \%$ & $20 \%$ & $34 \%$ & $56 \%$ & $27 \%$ \\
\hline Penghapusan & $20 \%$ & $9 \%$ & $11 \%$ & $16 \%$ & $14 \%$ \\
\hline Biaya oprs. Lainnya & $14 \%$ & $15 \%$ & $15 \%$ & $15 \%$ & $15 \%$ \\
\hline Total Biaya & $99 \%$ & $100 \%$ & $98 \%$ & $95 \%$ & $99 \%$ \\
\hline Biaya Non Oprs. & $1 \%$ & $0 \%$ & $2 \%$ & $5 \%$ & $1 \%$ \\
\hline
\end{tabular}

Kredit non lancar: A: <5 \%, B: $5-<10 \%$, C: $10-25 \%$, D: > 25\%

b. Pada kelas asset A porsi biaya untuk pegawai paling dominan (42\%) dibandingkan biayabiaya lainnya, sementara biaya dana hanya $15 \%$. Pada kelas asset $\mathrm{C}$ porsi pengeluaran biaya yang dominan adalah biaya dana (30\%), sementara biaya operasional lainnya hanya $15 \%$.

c. Struktur biaya tergantung pada skala operasi BPRS yang bersangkutan dan seberapa luas nasabah yang dilayaninya. Semakin besar volume usaha BPRS maka semakin efisien. 
Mereka mengeluarkan biaya pegawai hanya sebesar 25\% dari total biaya dan biaya operasional lainnya sebesar 14\%, sedangkan BPRS kecil (A) mengeluarkan biaya pegawai sebesar $42 \%$ dari total biaya dan biaya operasional lainnya sebesar $19 \%$.

Apabila dilihat dari kelas kinerja kredit BPRS maka dapat digambarkan sebagai berikut (lihat tabel III.4):

a. Pendapatan dari pembiayaan (kredit) berperanan dominan pada masing-masing kelas kinerja kredit. Hal ini dapat dimaklumi karena kegiatan pokok bank adalah pelaksanaan pembiayaan. Pendapatan dari pembiayaan pada BPRS kelas kinerja kredit paling baik (A) sebesar 97\% dari total pendapatan sedangkan kelas kinerja kredit paling buruk sebesar $43 \%$.

b. BPRS dengan kinerja kredit paling baik (A) mengeluarkan biaya penghimpunan dana sebesar 30\% dari total biaya, sedangkan BPRS dengan kinerja paling buruk mengeluarkan biaya penghimpunan dana sebesar $8 \%$.

Gambar 2 menyajikan struktur pendapatan dan biaya rata-rata BPRS berdasarkan kelas asset dan kelas kinerja kredit. Berdasarkan unsur pendapatannya ternyata pendapatan utama BPRS diperoleh dari kegiatan penyaluran pembiayaan yang mencapai $71 \%$ dari total pendapatan bank, sedangkan penempatan antar bank mencapai $17 \%$.

Apabila dilihat dari biaya rata-rata yang dikeluarkan, biaya dana termasuk bagi hasil (bunga) pinjaman yang diterima dan bunga untuk tabungan dan deposito mencapai $31 \%$ dari total biaya yang dikeluarkan, sedangkan biaya operasional lainnya mencapai $66 \%$ dari pengeluaran biaya keseluruhan.

Berdasarkan kelas asset, pendapatan rata-rata BPRS kelas asset A sebesar $50 \%$ berasal dari kegiatan pembiayaan (kredit), dan sebesar 28\% dari ABA, sedangkan BPRS pada kelas asset $\mathrm{C}$ sebesar $91 \%$ berasal dari kegiatan pembiayaan (kredit), dan sebesar 6\% dari ABA. Di lain pihak biaya rata-rata yang dikeluarkan BPRS pada kelas asset A sebesar $81 \%$ untuk biaya operasional lainnya dan sebesar 13\% untuk biaya penghimpunan dana, sedangkan BPRS pada kelas asset C biaya operasional lainnya sebesar $51 \%$ dan sebesar $49 \%$ biaya penghimpunan dana.

Jika dilihat dari kelas kinerja kredit, struktur pendapatan dan biaya BPRS tidak bervariasi kecuali pada kelas kinerja kredit B. BPRS dalam kelas B umumnya BPRS kecil dengan kinerja kredit yang baik, dengan pengeluaran biaya lebih rendah, dengan memperoleh pendapatan yang lebih tinggi berasal dari kegiatan penyaluran pembiayaan. 
Gambar 2

Struktur Pendapatan dan Biaya Rata-Rata BPR Syariah

\begin{tabular}{|c|c|c|c|}
\hline \multicolumn{4}{|c|}{ Kelas Asset A } \\
\hline Pos L/R & Nilai & Pos L/R & Nilai \\
\hline $\begin{array}{r}\text { Bunga bank } \\
\text { Pend. } \\
\text { Pembiayaan }\end{array}$ & $28 \%$ & $\begin{array}{r}\text { Bya.pendanaan } \\
\text { Bya }\end{array}$ & $13 \%$ \\
\hline
\end{tabular}

\begin{tabular}{|c|c|c|c|}
\hline \multicolumn{4}{|c|}{ Kelas Kinerja Kredit A } \\
\hline Pos L/R & Nilai & Pos L/R & Nilai \\
\hline $\begin{array}{r}\text { Bunga bank } \\
\text { Pend. }\end{array}$ & $36 \%$ & Bya.pendanaan & $31 \%$ \\
Pembiayaan & $62 \%$ & Opr lainnya* & $67 \%$ \\
\hline
\end{tabular}

\begin{tabular}{|c|c|c|c|}
\hline \multicolumn{4}{|c|}{ Kelas Kinerja Kredit B } \\
\hline Pos L/R & Nilai & Pos L/R & Nilai \\
\hline $\begin{array}{r}\text { Bunga bank } \\
\text { Pend. } \\
\text { Pembiayaan }\end{array}$ & $2 \%$ & $\begin{array}{r}\text { Bya.pendanaan } \\
\text { Bya }\end{array}$ & $56 \%$ \\
\hline Opr lainnya* & $44 \%$ \\
\hline
\end{tabular}

\begin{tabular}{|c|c|c|c|}
\hline \multicolumn{4}{|c|}{ Kelas Asset C } \\
\hline Pos L/R & Nilai & Pos L/R & Nilai \\
\hline $\begin{array}{r}\text { Bunga bank } \\
\text { Pend. } \\
\text { Pembiayaan }\end{array}$ & $91 \%$ & $\begin{array}{r}\text { Bya.pendanaan } \\
\text { Bya }\end{array}$ & $49 \%$ \\
Opr lainnya* & $51 \%$ \\
\hline
\end{tabular}

\begin{tabular}{|c|c|c|c|}
\hline \multicolumn{4}{|c|}{ Kelas Kinerja Kredit C } \\
\hline Pos L/R & Nilai & Pos L/R & Nilai \\
\hline $\begin{array}{r}\text { Bunga bank } \\
\text { Pend. }\end{array}$ & $14 \%$ & $\begin{array}{r}\text { Bya.pendanaan } \\
\text { Bya }\end{array}$ & $31 \%$ \\
$\begin{array}{r}\text { Pembiayaan } \\
\text { Opr lainnya*) }\end{array}$ & $63 \%$ & $65 \%$ \\
\hline
\end{tabular}

\begin{tabular}{|c|c|c|c|}
\hline \multicolumn{4}{|c|}{ BPR di Jatim } \\
\hline Pos L/R & Nilai & Pos L/R & Nilai \\
\hline $\begin{array}{r}\text { Bunga bank } \\
\text { Pend. } \\
\text { Pembiayaan }\end{array}$ & $71 \%$ & $\begin{array}{r}\text { Bya.pendanaan } \\
\text { Bya }\end{array}$ & $31 \%$ \\
Opr lainnya* & $66 \%$ \\
\hline
\end{tabular}

\begin{tabular}{|c|c|c|c|}
\hline \multicolumn{4}{|c|}{ Kelas Kinerja Kredit D } \\
\hline Pos L/R & Nilai & Pos L/R & Nilai \\
\hline $\begin{array}{r}\text { Bunga bank } \\
\text { Pend. } \\
\text { Pembiayaan }\end{array}$ & $0 \%$ & $\begin{array}{r}\text { Bya.pendanaan } \\
\text { Bya }\end{array}$ & $8 \%$ \\
Opr lainnya*) & $87 \%$ \\
\hline
\end{tabular}

*) Biaya operasional lainnya termasuk biaya penghapusan kredit macet.

\subsubsection{Klasifikasi Asset}

Apabila 6 BPRS yang ada di Jawa Timur dibagi dalam kelas asset terlihat hanya ada pada kelas asset di bawah Rp. 500 juta (A) dan pada kelas asset Rp.1 milyar sampai dengan Rp.5 milyar (C). Jumlah asset rata-rata BPRS per Desember 1999 sebesar Rp.1,2 Milyar.

Jangka waktu beroperasi berhubungan positif dengan perkembangan asset yaitu semakin lama BPRS beroperasi maka semakin besar jumlah assetnya. Hal ini tergambar pada BPRS yang masa operasionalnya 3 tahun memiliki asset rata-rata Rp.0,3 juta, sedangkan pada BPRS pada kelas $C$ yang sudah beroperasi rata-rata 5 tahun memiliki asset rata-rata Rp. 2,2 juta. 
Tabel III.5:

Kelas Asset BPR syariah terhadap Indikator Terpilih

\begin{tabular}{|c|c|c|}
\hline \multirow{2}{*}{ Ura i a n } & \multicolumn{2}{|c|}{ Kelas Asset } \\
\hline & $\mathbf{A}$ & $\mathrm{C}$ \\
\hline $\mathrm{Jml}$ BPR $(\%)$ & 50 & 50 \\
\hline Rata-rata Tahun Operasi & 3,0 & 5,0 \\
\hline Rata-rata Asset (Rp.juta) & 0,3 & 2,2 \\
\hline$\%$ Portofolio kredit/Asset & & \\
\hline Rata2 \% & 53,6 & 73,5 \\
\hline$\% \mathrm{BPR}<60 \%$ & 50,0 & 0,0 \\
\hline$\% \mathrm{BPR}>85 \%$ & 0,0 & 17,0 \\
\hline Rata- 2 outstanding kredit & & \\
\hline Rata2 (Rp. juta) & 1,0 & 2,3 \\
\hline$\%$ BPR $<$ Rp 1 juta & 33,0 & 0 \\
\hline$\%$ BPR > Rp. 2 juta & 0,0 & 17 \\
\hline$\%$ Kredit Non Lancar & & \\
\hline $\operatorname{Rata} 2(\%)$ & 28,0 & 12 \\
\hline$\% \mathrm{BPR}<10 \%$ & 17,0 & 33 \\
\hline$\% \mathrm{BPR}>25 \%$ & 17,0 & 0 \\
\hline
\end{tabular}

Keterangan:

A: < Rp.500 juta; C: Rp.1 M - Rp.5 M

\subsubsection{Portofolio Kredit dan Rata-Rata Outstanding Kredit.}

Rata-rata prosentase portofolio pinjaman terhadap asset pada BPRS kelas asset A lebih rendah dibandingkan BPRS kelas $\mathrm{C}$. Dari rasio pinjaman terhadap asset, BPRS dengan asset kecil (kelas asset A), cenderung menemui kesulitan dalam mendapatkan calon peminjam yang layak, dan sejalan dengan bertambahnya jangka waktu operasi BPRS semakin mampu mendapatkan peminjam yang layak, hal ini terlihat dari BPRS pada kelas A dengan rata-rata operasional 3 tahun rasio rata-rata kredit terhadap asset sebesar $54 \%$ dan BPRS kelas C dengan rata-rata operasional 5 tahun dengan rasio rata-rata kredit terhadap asset sebesar $74 \%$.

Jumlah rata-rata pinjaman per nasabah yang disalurkan BPRS sangat berbeda antar kelas asset contoh; kelas A sebesar Rp.1,2 juta per nasabah, sedangkan pada kelas C sebesar Rp.3,1 per nasabah. Seperti juga pada porsi kredit terhadap asset, rata-rata outstanding kredit meningkat sejalan dengan bertambahnya asset BPRS. Pada umumnya BPRS kelas asset besar (A) menyalurkan kredit di bawah Rp.1 juta per nasabah, namun pada BPRS dengan asset besar (C) mempunyai rata-rata outstanding kredit di atas Rp.1 juta sampai dengan Rp.2 juta per nasabah.

NPL BPRS pada kelas asset A lebih buruk dibandingkan dengan kelas asset C. Dari 3 BPRS pada kelas A, satu BPRS sedang mengalami masalah struktural yakni $68 \%$ pembiayaannya adalah non lancar. 


\subsection{Organisasi dan Manajemen}

\subsubsection{Struktur Organisasi}

Dalam bab organisasi dan manajemen berikut akan dibahas hal-hal yang berhubungan dengan organisasi yaitu: struktur organisasi, kepemilikan, komposisi dari personil BPRS. Untuk manajemen akan dibahas hal-hal yang berhubungan dengan kewenangan manajemen, manajemen secara umum, manajemen perkreditan dan keuangan, masalah yang dihadapi oleh manajemen serta kebutuhan pelatihan bagi SDM BPR.

Struktur organisasi BPRS tergantung pada jumlah asset masing-masing BPRS, semakin besar jumlah asset BPRS maka struktur organisasinya semakin komplek. Struktur organisasi BPRS pada dasarnya sama dengan BPR konvensional, kecuali dalam BPRS terdapat unsur dewan syariah.

Struktur organisasi BPRS (gambar 3) yang paling sederhana dengan jumlah asset sebesar Rp.111,9 juta per akhir tahun 1999 memiliki pegawai 5 orang terdiri dari satu orang direktur, dibantu satu orang staf direktur ditambah tiga orang yang masing-masing mengisi tiga bagian yakni bagian pembiayaan (d.h.i kredit pada BPR konvensional), bagian operasional, dan bagian umum. BPRS yang didirikan pada bulan Oktober 1994 ini, sampai saat ini tidak mengalami perkembangan kegiatan usaha, dengan tingkat kesehatan Tidak Sehat. Jumlah dewan pengawas syariah dan dewan komisaris masing-masing terdiri dari 2 orang, dan BPRS tersebut sampai saat ini belum membentuk satuan kerja internal audit.

Gambar 3

Struktur Organisasi Sederhana BPR Syariah

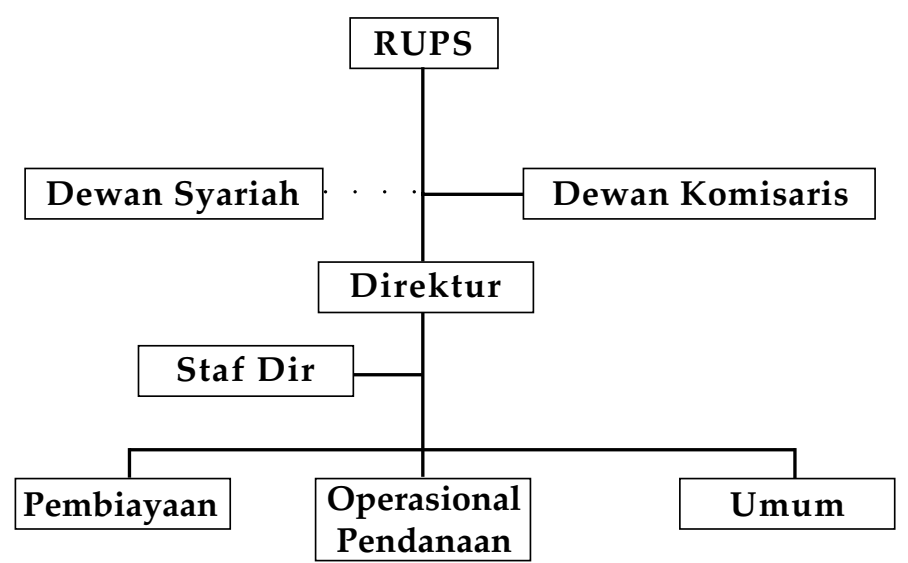

Struktur organisasi pada gambar 4 adalah struktur organisasi dari BPRS dengan jumlah asset Rp. 1,9 milyar per akhir tahun 1999, merupakan asset tertinggi kedua BPRS di Jatim, 
didirikan lima tahun yang lalu. Dua orang direksi memimpin 15 orang pegawai, yang dibagi menjadi dua bagian dengan beberapa seksi. BPRS ini juga memiliki kantor pelayanan kas, yang secara fungsional bertanggung jawab kepada kepala bagian marketing. Fungsi personalia, legal dan audit dirangkap oleh kepala bagian dan direksi. Dalam kasus lain, BPRS dengan total asset lebih rendah mempunyai struktur organisasi serupa namun memiliki bagian yang lebih banyak (empat bagian; bagian umum, pemasaran, kasir/teller, dan akutansi), dengan beberapa seksi (sub-bagian).

\section{Gambar 4}

Struktur Organisasi dengan Bagian BPR Syariah

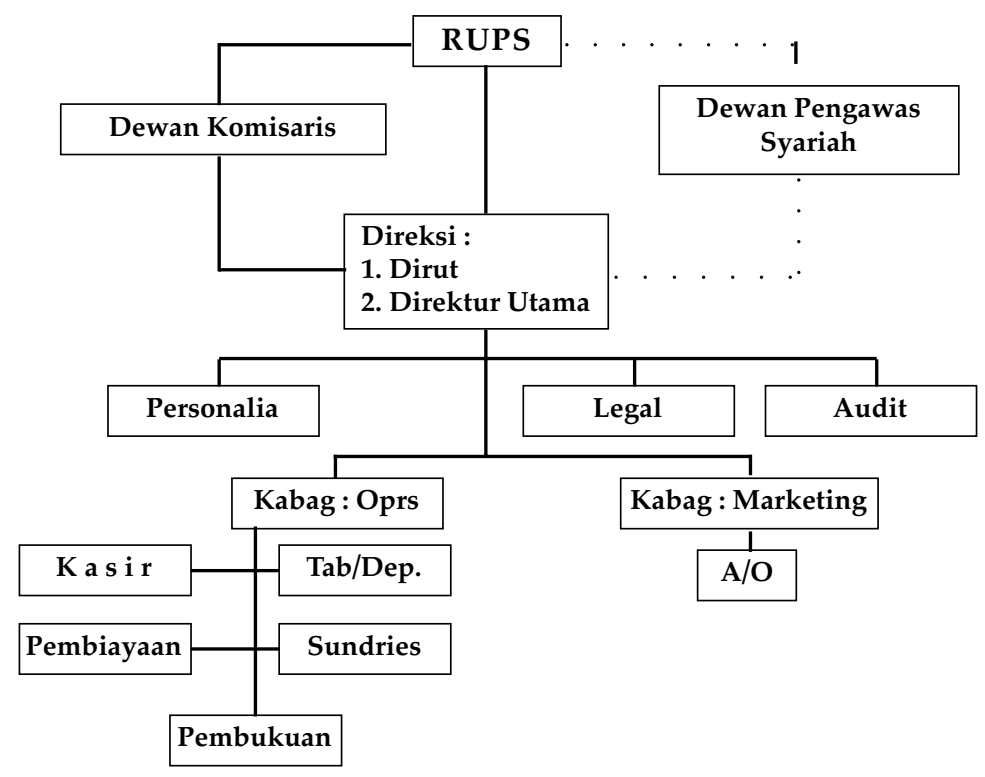

Bentuk model organisasi ke tiga (Gambar 5) adalah struktur organisasi dari BPRS terbesar di Jawa Timur yang didirikan setelah diberlakukan Undang-Undang Perbankan No 7 tahun 1992 dan berbadan hukum perseroan terbatas. BPRS yang didirikan pada tahun 1994 ini memiliki jumlah asset sebesar Rp.3,077 milyar dengan jumlah pegawai sebanyak 22 orang dan memiliki satu kantor unit pelayanan. BPRS ini memiliki bagian perencanaan, penelitian dan pengembangan, namun untuk bagian pembiayaan (kredit pada sistem konvensional), disatukan dalam bagian yang sama dengan seksi yang berbeda. Dalam bagian pembiayaan terdapat seksi-seksi legal support (adm.pembiayaan), appraisal (analis pembiayaan), credit support, dan remedial (pembiayaan bermasalah). 
Gambar 5.

Struktur Organisasi dengan Kantor Cabang BPR Syariah

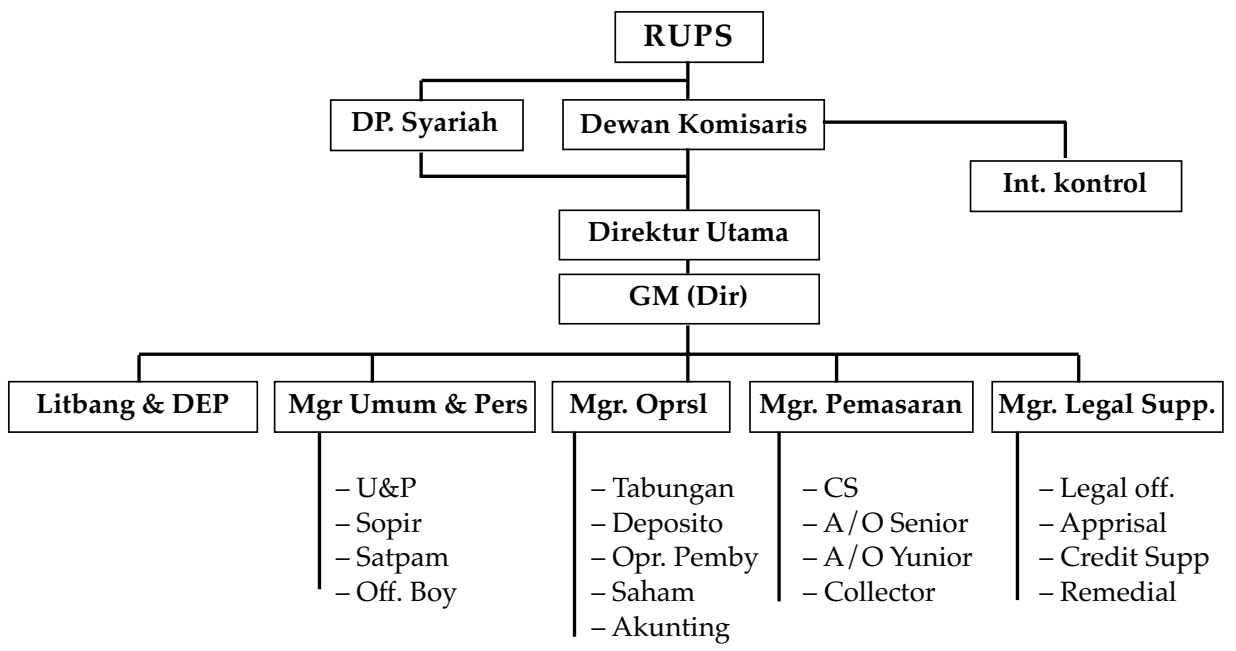

BPRS telah memiliki internal kontrol namun penempatan internal kontrol pada struktur organisasi BPRS beragam. Terkadang internal kontrol ditempatkan di atas direktur utama seperti pada gambar 5, atau di bawah direktur utama seperti pada gambar 4. Dari dua macam penempatan internal kontrol pada BPRS di atas nampaknya terdapat perbedaan pengertian internal kontrol, yang pertama sebagai fungsi dari operasional direktur dan yang lainnya sebagai fungsi dari pengawasan dewan komisaris.

\subsubsection{Kepemilikan dan Dewan Komisaris}

Jumlah rata-rata pemegang saham BPRS adalah 57 pemegang saham, dengan tertinggi 170 pemegang saham dan terendah 4 pemegang saham. BPRS dengan 4 pemegang saham merupakan BPRS yang baru setahun beroperasi yang sebelumnya adalah telah beroperasi sebagai BPR konvensional, sehingga dari sisi variasi pemilikan saham masih berciri BPR konvensional. Di lain pihak BPRS yang mempunyai pemegang saham 170 adalah BPRS yang memiliki asset terbesar di Jatim dengan sistem kepemilikan yang terbuka. Komitmen dari pendiri BPRS di Jawa Timur adalah untuk melibatkan masyarakat umum seluas-luasnya dalam memiliki saham BPRS, hal ini terlihat dari variasi jumlah pemegang sahamnya pada angka dua digit. Selain itu BPRS di Jatim pada umumnya didirikan oleh salah satu ormas Islam dan kepemilikannya sangat terbuka.

Jumlah dewan komisaris pada BPRS rata-rata 4 orang, dan seluruh dewan komisaris berasal dari pemegang saham, yang pada umumnya para pelopor pendirian BPRS. 
Bila dilihat dari latar belakang pengalaman di bidang perbankan maka anggota dewan komisaris mayoritas tidak mempunyai pengalaman. Hanya 19\% dari seluruh komisaris yang mempunyai latar belakang pendidikan/pengalaman di bidang perbankan, dengan tingkat pendidikan pada umumnya sarjana $(81 \%)$.

Tabel III.6 :

Kepemilikan BPR dan Pegawai BPR Syariah

\begin{tabular}{|c|c|}
\hline & BPRS $^{* *}$ ) \\
\hline Jml BPRS & 6 \\
\hline Kepemilikan & \\
\hline Rata-rata pemegang saham & 57,0 \\
\hline$\%$ BPR dgn 1 pemegang saham & 0,0 \\
\hline$\%$ BPR dgn 2 pemegang saham & 0,0 \\
\hline$\%$ BPR dgn 3-5 pemegang shm & 16,7 \\
\hline$\%$ BPR dgn $>5$ pemegang shm & 83,3 \\
\hline Rata2 jmlh BPR dgn pgm shm $>50 \%$ & 0,0 \\
\hline Dewan komisaris & \\
\hline$\%$ BPR dgn 1 org komisaris & 0,0 \\
\hline$\%$ BPR dgn 2 org komisaris & 16,7 \\
\hline$\%$ BPR dgn $>2$ org komisaris & 83,3 \\
\hline Pengalaman di perbankan & \\
\hline$\%$ rata2 dari komisaris & 19,2 \\
\hline Tdk berpengalaman (\% BPR) & 66,7 \\
\hline Pendidikan $<=$ SLTA & \\
\hline$\%$ rata 2 dari komisaris & 19,2 \\
\hline Jumlah komisaris (\% BPR) & 50,0 \\
\hline Pegawai BPR & \\
\hline Jml rata2 & 13,0 \\
\hline Jml rata2 direktur & 2,0 \\
\hline Jml rata2 pegawai tetap. & 9,0 \\
\hline Direktur BPR & \\
\hline 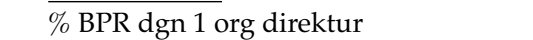 & 16,7 \\
\hline$\%$ BPR dgn 2 org direktur & 83,3 \\
\hline$\%$ BPR dgn $>2$ org direktur & 0,0 \\
\hline Pengalaman di perbankan & \\
\hline$\%$ rata2 dari direktur & 55,0 \\
\hline Jumlah direktur (\% BPR) & 83,0 \\
\hline Pendidikan $<=$ SLTA & \\
\hline$\%$ rata2 dari direktur & 0,0 \\
\hline Jumlah direktur (\% BPR) & 0,0 \\
\hline Pegawai Tetap & \\
\hline$\%$ BPR dgn 2-9 peg.tetap & 66,7 \\
\hline$\%$ BPR dgn 10-19 peg.tetap & 33,3 \\
\hline$\%$ BPR dgn $>20$ org peg.tetap & 0,0 \\
\hline Pengalaman di perbankan & \\
\hline$\%$ rata2 dari peg.tetap & 16,4 \\
\hline Jlh peg.tetap tdk pengalaman (\% BPR) & 33,3 \\
\hline Pendidikan $<=$ SLTA & \\
\hline$\%$ rata 2 dari peg.tetap & 36,4 \\
\hline Seluruh peg.tetap $<=$ SLTA $(\%$ BPR $)$ & 0 \\
\hline
\end{tabular}

**) Angka prosentase diperoleh dari membandingkan dengan total BPRS di Jatim. 
Pada struktur organisasi BPRS terdapat Dewan Pengawas Syariah yang memiliki anggota rata-rata 3 orang. Dewan Pengawas Syariah bertugas untuk memastikan produk yang dihasilkan oleh BPRS dan sistem operasional yang diterapkan apakah sudah sesuai dengan syariah Islam. Mereka rata-rata memiliki latar belakang pengetahuan agama Islam yang baik dan merupakan orang yang dihormati karena pengetahuan agama Islamnya baik. Namun pada umumnya mereka tidak mempunyai pengalaman di bidang perbankan, kecuali pada satu BPRS, tingkat pendidikan dewan pengawas umumnya adalah sarjana, namun ada juga yang hanya berlatar belakang pondok pesantren (sekolah informal yang lebih dominan memberikan pengetahuan agama Islam).

\subsubsection{Komposisi Manajemen dan Pegawai BPRS}

Manajemen BPRS umumnya terdiri dari dua orang direktur (83\%), hanya satu BPRS yang masih dipimpin oleh satu direktur yakni BPRS hasil konversi dari BPR konvensional dengan total asset sebesar Rp.0,4 milyar per Desember 1999.

Mayoritas (83\%) BPRS dipimpin oleh direktur yang mempunyai latar belakang pengalaman di bidang perbankan, dengan tingkat pendidikan formal minimal sarjana muda dan 50\% lebih direktur-direktur BPRS tersebut memiliki pengalaman di bidang perbankan.

Rata-rata jumlah pegawai BPRS adalah 14 orang, yang terdiri dari 11 orang pegawai tetap (termasuk direktur), dan 3 orang pegawai tidak tetap. Pegawai tidak tetap pada umumnya sebagai tenaga kolektor tabungan dan pembiayaan (kredit). Tingkat pendidikan pegawai tetap BPRS umumnya di atas SLTA (64\%), dan belum memiliki pengalaman di bidang perbankan.

\subsubsection{Wewenang Manajemen}

Untuk menilai tingkat wewenang manajemen (direksi) BPRS maka dinilai kewenangan mengambil keputusan dari direksi dalam 6 bidang yaitu: penerimaan staf baru, pembelian asset tetap, manajemen asset dan liabilities, persyaratan perkreditan, serta persetujuan kredit.

Dalam menganalisa tingkat wewenang manajemen BPRS berdasarkan informasi yang diperoleh dari hasil survey dapat dibagi empat tingkatan level manajemen yaitu; (1), wewenang yang tinggi tanpa keterlibatan dari pemilik atau komisaris, (2), wewenang yang relatif tinggi dengan keterlibatan pemilik atau komisaris pada beberapa bidang seperti yang disebut sebelumnya, (3), wewenang manajemen yang relatif rendah dengan keterlibatan pemilik atau komisaris melebihi 50\% dari bidang, (4), wewenang rendah karena pemilik atau komisaris terlibat dalam pengambilan keputusan operasional di semua bidang. 
Tabel III.7 :

Wewenang Manajemen BPR Syariah

\begin{tabular}{|c|c|}
\hline & BPRS $^{* *}$ ) \\
\hline Jml BPR & 6 \\
\hline \multicolumn{2}{|l|}{ Keterlibatan Pemilik (\% BPR) } \\
\hline Keterlibatan dlm operasional & 0,0 \\
\hline \multicolumn{2}{|l|}{ Wewenang manajemen: } \\
\hline Tinggi & 50,0 \\
\hline Relatif Tinggi & 50,0 \\
\hline Relatif Rendah & 0,0 \\
\hline Rendah & 0,0 \\
\hline \multicolumn{2}{|l|}{ Manajemen Umum (\% BPR) } \\
\hline Keberadaan rencana tahunan & 100,0 \\
\hline Keberadaan rencana training & 100,0 \\
\hline Keberadaan anggaran training & 100,0 \\
\hline Keberadaan job discription & 100,0 \\
\hline Keberadaan sistem internal & 66,7 \\
\hline \multicolumn{2}{|l|}{ Keberadaan manual: } \\
\hline Adm. Dan pembukuan & 100,0 \\
\hline Analis kredit & 100,0 \\
\hline Prosedur pesetujuan kredit & 100,0 \\
\hline Batas pinjaman & 83,0 \\
\hline Pinjaman ke pihak terkait & 66,0 \\
\hline Pengawasan pinjaman & 100,0 \\
\hline \multicolumn{2}{|l|}{ Manajemen keuangan/pinjaman } \\
\hline \multicolumn{2}{|l|}{ Keberadaan kebijakan: } \\
\hline Manajemen likuiditas & 83,0 \\
\hline BMPK & 100,0 \\
\hline BMPK ke pihak terkait & 50,0 \\
\hline PPAP & 100,0 \\
\hline Penghapusan kredit macet & 50,0 \\
\hline \multicolumn{2}{|l|}{ Eksekusi agunan: } \\
\hline Tidak Pernah & 100,0 \\
\hline Pernah lebih dari satu kali & 0,0 \\
\hline Pernah dgn hasil yg memuaskan & 0,0 \\
\hline \multicolumn{2}{|l|}{ Lima outstanding kredit terbesar } \\
\hline$<10 \%$ dari portofolio kredit & 33,0 \\
\hline$>30 \%$ dari portofolio kredit & 17,0 \\
\hline
\end{tabular}

**) Angka prosentase diperoleh dari membandingkan dengan total BPRS di Jatim.

Keterlibatan pemilik dalam pengambilan keputusan bidang operasional BPRS dapat melalui anggota dewan komisaris, direksi, atau bentuk campur tangan lainnya. Berdasarkan hasil survey ternyata BPRS di Jatim dapat dimasukkan dalam dua macam tingkat kewenangan yakni tingkat kewenangan "tinggi" dan "relatiftinggi" masing-masing adalah $50 \%$ (lihat tabel III.8). 
Bentuk keterlibatan pada 3 BPRS dengan tingkat kewenangan "relatif tinggi" adalah dalam bidang pembelian aktiva tetap, penerimaan pegawai, dan manajemen sumber dan penyaluran dana.

Tabel III.8 :

Indikator Manajemen terhadap Penggolongan

Kinerja Pembiayaan (kredit)

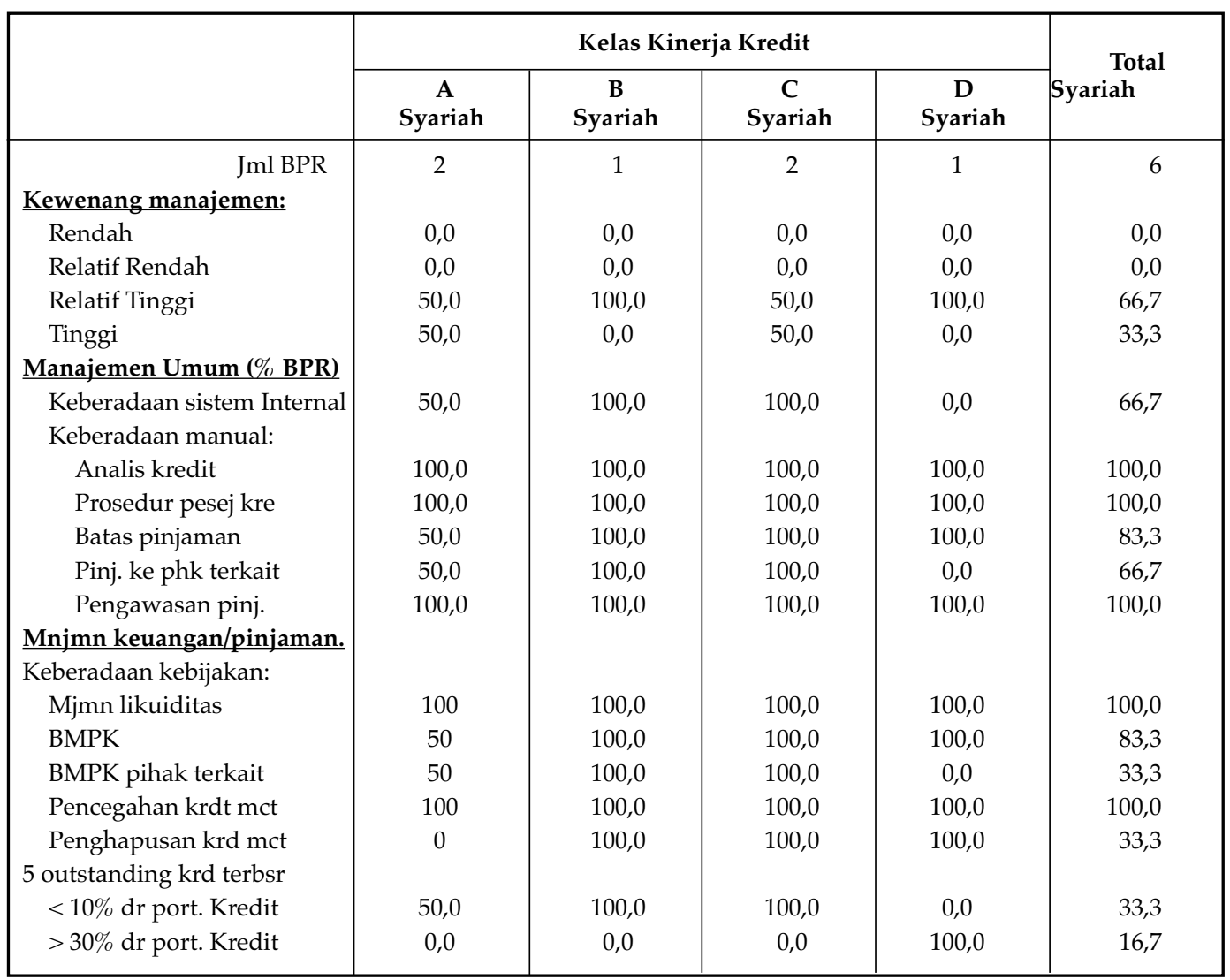

**) Angka prosentase diperoleh dari membadingkan dengan total BPRS di Jatim.

- Kredit Non lancar: A: <5\%, B: $5-<10 \%$, C: 10-25\%, D: $>25 \%$.

Hal yang menarik jika variabel kewenangan dihubungkan dengan variabel kualitas aktiva produktif. Walau sedikit lebih sulit melihat fenomena ini, karena BPRS beroperasi pada tingkat kewenangan tinggi dan relatif tinggi. BPRS dengan tingkat kewenang tinggi mempunyai NPL lebih kecil dari 5\% sedangkan BPRS beroperasi dengan kewenangan relatif tinggi mempunyai NPL lebih besar dari $5 \%$.

Temuan ini tidak dapat diartikan bahwa campur tangan pemilik, khususnya dalam keputusan pemberian pembiayaan (kredit), akan mempengaruhi kinerja kreditnya. Namun 
demikian, hal ini menunjukan bahwa banyaknya campur tangan pemilik dalam operasional BPRS tidak membantu meningkatkan kinerja kreditnya.

Direksi mempunyai kewenangan yang sangat rendah dalam membeli aktiva tetap, sebanyak 83\% BPRS melakukannya atas persetujuan dari pemilik. Mayoritas kewenangan dalam penerimaan pegawai tidak dipengaruhi oleh komisaris $(67 \%)$. Untuk manajemen sumber dan penyaluran dana biasanya diserahkan kepada direksi. Keterlibatan pemilik dalam manajemen dana hanya ada pada satu BPRS (16\%). Kewenangan yang paling tinggi bagi direksi ada pada penentuan tingkat bunga, dan penentuan persyaratan pinjaman (masing-masing 100\%).

\subsubsection{Manajemen Umum}

Manajemen BPRS dapat dilihat dari rencana tahunan BPRS dan uraian tugas (job discription). Target BPRS dalam rencana kerja tahunan adalah peningkatan cakupan pelayanan, disusul dengan peningkatan kualitas SDMnya, peningkatan laba, modal disetor dan kinerja BPRS khususnya di bidang pembiayaan, baik penyaluran maupun penagihan. Pada umumnya BPRS sangat menyadari bahwa sistem yang mereka tawarkan kepada masyarakat relatif baru, untuk itu dalam rencana kerja tahunan kebanyakan BPRS mencantumkan tujuan utama adalah lebih memperkenalkan sistem pelayanan melalui pembukan unit-unit pelayanan baru kemudian peningkatan kualitas SDM, sedangkan target kuantitatif menjadi tujuan operasional nomer dua. Target kuantitatif dapat berupa peningkatan penyaluran pembiayaan, penghimpunan dana pihak ketiga (DPK) dan lainlain. Tabel berikut ini memperlihatkan 10 tujuan yang sering dicantumkan dalam rencana kerja tahunan BPRS.

Tabel III.9 :

Rangking Tujuan pada Rencana kerja Tahunan

\begin{tabular}{|l|c|c|}
\hline \multicolumn{1}{|c|}{ Faktor } & \multicolumn{2}{c|}{ BPRS Jatim } \\
\cline { 2 - 3 } R = Rangking N = Jumlah BPR & R & N=6 \\
\hline Menigkatkan penghimpunan dana, asset & - & - \\
Meningkatkan pemberian pembiayaan/kredit & - & - \\
Meningkatkan kemampuan SDM & 2 & 2 \\
Meningkatkan kualitas aktiva produktif & - & - \\
Meningkatkan pendapatan / BEP & 3 & 1 \\
Meningkatkan/menjaga tingkat kesehatan bank & 3 & 1 \\
Mendirikan/mempeluas unit layanan & 1 & 4 \\
Mengembangkan program komputerisasi kantor & 2 & 2 \\
Meneriman pegawai baru- & - & \\
Meningkatkan motivasi/ disiplin pegawai & - & - \\
Meningkatkan manajemen/internal kontrol & - & - \\
Meningkat modal disetor & 3 & 1 \\
\hline
\end{tabular}


Semua BPRS telah memiliki uraian tugas para pegawainya yang menjelaskan mengenai hal-hal yang harus dilakukan dan tanggungjawab masing-masing pegawai. Namun demikian keberadaan dari uraian tugas tidak menjamin BPRS memiliki kinerja kredit baik. Oleh karena itu diperlukan komitmen manajemen bank untuk melaksanakan job manual secara disiplin agar dapat dicapai kinerja yang baik.

\subsubsection{Manajemen Keuangan dan Kredit}

Pembahasan mengenai manajemen keuangan dan perkreditan dilakukan dengan melihat praktek penerapan kedua jenis manajemen tersebut dalam operasional BPRS. Untuk manajemen keuangan dilihat melalui penerapan manajemen likuiditas, sedangkan manajemen kredit menyangkut aspek-aspek perkreditan seperti; penyebab, strategi untuk menghindari kredit bermasalah, tindakan yang dilakukan jika terjadi kemacetan, BMPK, penghapusbukuan, dan eksekusi jaminan. Pada bagian akhir diungkapkan masalah utama yang dihadapi dalam operasional BPRS.

\section{A. Manajemen likuiditas}

Manajemen likuiditas terutama berhubungan dengan penyediaan kas untuk menyelesaikan hutang jangka pendek dan untuk itu perlu pencocokan antara hutang lancar dengan tagihan lancar. Biasanya bank akan membuat proyeksi aliran kas sesuai dengan jatuh tempo (jangka waktu) hutang dan tersedianya kas yang diperoleh dari tagihan lancar.

Tabel III.10 :

Ranking terhadap Manajemen Likuiditas

\begin{tabular}{|l|c|c|}
\hline \multicolumn{1}{|c|}{ Faktor } & \multicolumn{2}{|c|}{ BPRS Jatim } \\
\cline { 2 - 3 } $\mathbf{R}=$ Rangking N = Jumlah BPR & $\mathbf{R}$ & $\mathbf{N}=\mathbf{6}$ \\
\hline Uang tunai/Simpanan pada bank lain .. \% dari DPK & 1 & 5 \\
Berdasarkan aliran kas sesuai dgn jangka waktunya & 2 & 2 \\
Likuiditas seperti pada CAMEL & 2 & 2 \\
BMPK kpd pihak terkait, meningkatkan kolektibilitas, & & - \\
mobilisasi tabungan. & & - \\
Program penjaminan simpanan & & - \\
Ketersedian modal tambahan, pinjaman dr phk terkait & & - \\
Lainnya dgn jawan tdk terinci & & \\
\hline
\end{tabular}

Bentuk pelaksanaan manajemen likuiditas yang dilakukan oleh BPR adalah sebagai berikut (lihat tabel III.10):

a. Melakukan praktek manajemen likuiditas yang benar seperti yang telah dijelaskan tersebut di atas (33\% BPRS). 
b. Menempatkan dana pada bank lain sebesar prosentase tertentu (biasanya dari 5\% s.d $20 \%$ ) dari dana yang berhasil dimobilisasi (83\% BPRS).

c. Menggunakan dua rasio likuiditas pada CAMEL yang diterapkan oleh BI (33\% BPRS). Cash rasio dan LDR dapat membantu untuk melihat posisi likuiditas BPRS tapi kurang tepat untuk mengukur kewajiban hutang jangka pendek, khususnya yang bersifat harian.

\section{B. Manajemen Kredit}

Faktor tertinggi yang menyebabkan pembiayaan (kredit) macet adalah kondisi ekonomi dan kegagalan usaha, baru kemudian faktor yang berhubungan dengan karakter, dan faktor eksternal lainnya.

Tabel III.11 :

Pengalaman BPR : Faktor yang menyebabkan kegagalan kredit

\begin{tabular}{|l|c|c|}
\hline \multicolumn{1}{|c|}{ Faktor } & \multicolumn{2}{c|}{ BPRS Jatim } \\
\cline { 2 - 3 } R = Rangking N = Jumlah BPR & $\mathbf{R}$ & $\mathbf{N}=\mathbf{6}$ \\
\hline FAKTOR YG BERHUB. DGN KARAKTER & 2 & 2 \\
Umum & - & 2 \\
Alamat berubah tanpa pemberitahuan & - & - \\
Kredit digunakan berbeda dgn kontrak & - & - \\
Kredit digunakan oleh pihak lain & - & - \\
Jaminan dijual oleh debitur & - & - \\
KONDISI EKONOMI \& KEGAGALAN BISNIS & 1 & 3 \\
FAKTOR INTERNAL BANK & - & - \\
Analisis dan prosedur kredit yg tdk memadai & - & - \\
Tdk ada atau kurangnya jaminan tetap & - & - \\
Kolusi dan campur tangan pihak luar & - & - \\
Tindakan terlambat, monitoring dan kurang bimbingan & - & - \\
FAKTOR EKTERNAL LAINNYA & 3 & 1 \\
Bencana alam atau pada manusia & - & - \\
Jaminan dijual hilang atau rusak & - & - \\
Tidak memakai jaminan & 4 & 1 \\
\hline
\end{tabular}

Secara umum dapat disimpulkan bahwa BPRS lebih dapat melihat karakter debiturnya, namun demikian tetap diperlukan kehati-hatian dalam menganalisa karakter calon nasabahnya, di samping pertimbangan ada tidaknya agunan.

Strategi yang dilakukan oleh BPRS untuk menghindari pembiayaan (kredit) macet adalah sebelum pemberian pembiayaan dilakukan analisis kelayakan, kemudian dilanjutkan tindakan-tindakan pengawasan/ pemantauan setelah pemberian kredit (lihat tabel III.12). 
Tabel III.12 :

Rangking Strategi untuk Menghindari Kredit Macet

\begin{tabular}{|l|c|c|}
\hline \multicolumn{1}{|c|}{ Strategi } & \multicolumn{2}{|c|}{ BPRS } \\
\cline { 2 - 3 } R = Rangking N = Jumlah BPR & R & N = 6 \\
\hline Monitoring kontinu, hubungan dan bimbingan secara pribadi & 2 & 3 \\
Informasi yg cukup dan analisa kredit yang Memadai (5C) & 1 & 6 \\
Jaminan yg cukup, dan jaminan yang mudah dijual & 3 & 2 \\
Berhati-hati dlm memilihan peminjan dan persetujuan kredit yg selektif & 4 & 1 \\
Meningkatkan kemampuan petugas kredit dan meningkatkan prosedur kredit & - & - \\
Penagihan kredit yg intensip dan membentu tim penyelamat kredit & 4 & 1 \\
Membuat komite kredit dan menyakinkan akan adanya keputusan kredit & & \\
yg transparan & - & - \\
Pembentukan cadangan penghapusan kredit macet yg cukup dan & & - \\
penghapus-bukuannya & - & - \\
Rescheduling, restructuring dan reconditioning thd kredit bermasalah & - & 1 \\
Lainnya atau jawaban tidak dirinci & 4 & \\
\hline
\end{tabular}

Tindakan yang diambil menajemen terhadap debitur jika mulai terjadi tanda-tanda kemacetan adalah diawali dengan kunjungan lebih sering terhadap debitur dan memberikan alternatif penyelesaian tunggakan, menagih secara langsung dan dapat juga dengan mengenakan pinalti terhadap keterlambatan angsuran. Di samping itu dikirim surat peringatan formal kepada debitur penunggak (lihat tabel III.13).

Tabel III.13:

Rangking tindakan yang diambil jika terjadi kemacetan

\begin{tabular}{|l|c|c|}
\hline \multicolumn{1}{|c|}{$\begin{array}{c}\text { T i n d a k a n } \\
\text { R = Rangking } \mathbf{~ N ~ = ~ J u m l a h ~ B P R ~}\end{array}$} & \multicolumn{2}{c|}{ B P R S } \\
\cline { 2 - 3 } & $\mathbf{R}$ & $\mathbf{N}=\mathbf{6}$ \\
\hline Kunjungan berkala, upaya penagihan dan Bimbingan & 1 & 6 \\
Menerapkan pinalti & 3 & 1 \\
Mengirimkan surat peringatan formal & 1 & 6 \\
Rescheduling, restructuring dan reconditioning thd kredit & 2 & 5 \\
Mengurangi pinalti dan bunga pinjaman & - & - \\
Mengikat jaminan & - & - \\
Lainnya atau tidak merinci jawaban & - & - \\
\hline
\end{tabular}

Ada praktek unik dari salah satu BPRS dalam usaha penagihan kredit, yaitu apabila surat peringatan pertama tidak mendapat tanggapan, maka dikirimkan surat peringatan yang tidak menggunakan amplop dan dikirimkan bukan melalui pos tapi melalui ketua RT atau kepala dusunnya. Hal ini akan menimbulkan rasa malu bagi debiturnya karena tunggakan angsurannya diketahui oleh ketua RT atau Kepala Dusun. 
Menurut mereka cara ini lebih efektif dibandingkan surat peringatan tersebut dikirimkan melalui pos.

Pengenaan denda jarang dilakukan oleh BPRS dan toleransi pengenaan denda pada masing-masing BPRS cukup beragam yaitu antara satu hari sampai dengan tiga bulan terhitung sejak terlambat. Pengenaan denda terkadang setelah atau bersamaan dengan upaya penagihan lainnya, sedangkan besarnya pengenaan finalti disesuaikan dengan kemampuan membayar debitur.

Sebelum melakukan eksekusi jaminan biasanya BPRS melakukan upaya penyelamatan seperti; penjadwalan, restrukturisasi, dan rekondisi.

Tabel III.14 :

Ranking pinjaman kepada pihak terkait

\begin{tabular}{|l|c|c|}
\hline \multicolumn{1}{|c|}{ Kebijaksanaan } & \multicolumn{2}{|c|}{ B P R S } \\
\cline { 2 - 3 } R = Rangking N = Jumlah BPR & R & N = 6 \\
\hline Menerapkan peraturan BI & 1 & 6 \\
Menyediakan bunga rendah, jangka waktu dan persyaratan yg lebih baik & 3 & 1 \\
Menerapkan peraturan kredit umumnya, sesuai dengan kemampuan & & \\
membayar & 2 & 2 \\
Menerapkan aturan jaminan yang baku & - & - \\
Hanya melayani keb yg sangat mendesak & 3 & 1 \\
Tidak menyediakan kredit pd pihak terkait & - & - \\
Menerapkan jumlah maks. Pinjaman Individual & - & - \\
\hline
\end{tabular}

Pembiayaan (kredit) kepada pihak terkait tidak digolongkan sebagai penyebab terjadi kredit bermasalah. Sebanyak 33\% BPRS memberikan kebijakan tertentu kepada pihak terkait dalam bentuk kemudahan dalam persyaratan pembiayaan (kredit). Namun semua BPRS dalam memberikan pembiayaan (kredit) kepada pihak terkait selalu memperhatikan BMPK yang ditetapkan oleh Bank Indonesia, karena menyadari jika melebihi BMPK akan mengurangi penilaian tingkat kesehatan BPRnya (lihat tabel III.14).

Seluruh BPRS menerapkan peraturan BPMK di mana untuk debitur individual tidak boleh meminjam lebih dari 20\% modal BPR (lihat tabel III.15).

Tujuan utama dari pemberlakuan pembatasan pemberian kredit (legal lending limit) adalah untuk menyebar resiko yang mungkin timbul dalam pemberian kredit. Salah satu alternatif yang ditawarkan oleh DR.Hendrik Prins (konsultan GTZ) untuk penghitungan BMPK adalah memberi batasan kredit kepada lima debitur pembiayaan terbesar dalam portofolio kredit BPRS tidak boleh lebih dari $20 \%$ total portofolio kredit. 
Tabel III.15 :

Ranking kebijakan BMPK

\begin{tabular}{|l|c|c|}
\hline \multicolumn{1}{|c|}{ Kebijakan } & \multicolumn{2}{|c|}{ B P R S } \\
\cline { 2 - 3 } $\mathbf{R}$ = Rangking N = Jumlah BPR & R & N = 6 \\
\hline $\begin{array}{l}\text { Menerapkan peraturan BI } \\
\text { Mengetatkan kewenangan manajemen dalam } \\
\text { menyetujui pemeberian kredit }\end{array}$ & - & 6 \\
$\begin{array}{l}\text { Diberikan kewenangan yg jelas oleh komisaris } \\
\text { dan direktur }\end{array}$ & - & - \\
$\begin{array}{l}\text { Menerapkan yang lebih ketat dibandingkan dgn } \\
\text { peraturan BI }\end{array}$ & - & - \\
$\begin{array}{l}\text { Membatasi pemberian kredit sesuai dgn } \\
\text { Keb. peminjam (analisis kredit yg benar) }\end{array}$ & - & - \\
$\begin{array}{l}\text { Menerapkan maks. kredit bagi debitur individual } \\
\text { Lainnya atau tidak merinci jawaban }\end{array}$ & - & - \\
\hline
\end{tabular}

Perbedaan porsi 5 pembiayaan besar dalam portofolio pembiayaan diantara BPRS kinerja terbaik sangat kecil (7\% ) jika dibandingkan dengan dan BPRS dengan kinerja terburuk (29\%). Hal ini jelas sekali mengambarkan bahwa BPRS dengan kinerja buruk memiliki resiko pembiayaan yang tinggi karena portofolio pembiayaan (kredit) mereka terserap kepada segelintir peminjam.

Ditemukan juga hal yang menarik adalah menghubungkan pelanggaran $20 \%$ porsi 5 pembiayaa (kredit) terbesar dengan tingkat campur tangan pemilik dalam operasional bank. BPRS mempunyai kinerja paling buruk beroperasi dengan tingkat kewenangan relatif tinggi melanggar batas 20\% 5 debitur terbesar, sedangkan BPRS yang beroperasi dengan tingkat kewenangan tinggi tidak melanggar.

Bidang lainnya yang dapat digali dari manajemen perkreditan BPRS adalah kebijakan dan praktek penghapusan kredit macet dan pengalaman eksekusi jaminan. BPRS kecil cenderung tidak menghapuskan kredit macet dari portofolio kreditnya karena alasan antara lain:

a. Masih mengharapkan dibayar walaupun sebenarnya sudah tidak ada harapan lagi;

b. Cadangan penghapusan aktiva produktif yang kurang.

Semua BPRS belum memiliki aturan intern penghapusan kredit macet. Pelaksanaan penghapuskan kredit yang dilakukan oleh BPRS adalah dengan persetujuan dari komisaris dan telah melewati waktu sejumlah bulan setelah dikategorikan macet atau dihapuskan diakhir tahun buku. Hal ini merupakan temuan penting jika dihubungkan jumlah BPRS yang non sehat (lihat tabel III.16). 
Tabel III.16 :

Ranking aturan penghapus-bukuan kredit macet

\begin{tabular}{|c|c|c|}
\hline Aturan & \multicolumn{2}{|c|}{ B P R S } \\
\hline $\mathbf{R}=$ Rangking $\mathbf{N}=$ Jumlah BPR & $\mathbf{R}$ & $\mathbf{N}=6$ \\
\hline $\begin{array}{l}\text { Menerapkan aturan yg sdh ada } \\
\text { Menghapusbukan sisa kredit jika jaminan } \\
\text { tidak cukup atau tdk mudah dipasarkan }\end{array}$ & 1 & 6 \\
\hline $\begin{array}{l}\text { Pengapusbukuan harus disetujui oleh } \\
\text { pemilik dan dewan komisaris }\end{array}$ & 3 & 1 \\
\hline $\begin{array}{l}\text { Penghapusbukuan berdasarkan pada } \\
\text { kapasitas PPAP }\end{array}$ & - & - \\
\hline $\begin{array}{l}\text { Penghapusbukuan setelah kredit (.. bln) } \\
\text { diklasifikasi macet }\end{array}$ & 2 & 3 \\
\hline $\begin{array}{l}\text { Menagih tunggakan setelah kredit di- } \\
\text { Hapusbukuan }\end{array}$ & - & - \\
\hline $\begin{array}{l}\text { Menyediakan cadangan kredit macet } \\
\text { dalam jumlah yang cukup }\end{array}$ & 3 & 1 \\
\hline $\begin{array}{l}\text { Menghapusbukan kredit macet pada } \\
\text { akhir tahun buku }\end{array}$ & - & - \\
\hline Lainnya tidak merinci jawaban & - & - \\
\hline
\end{tabular}

BPRS menerima agunan dalam bentuk tanah, gedung, kendaraan bermotor, atau aktiva tetap lainnya (seperti becak, sepeda, alat elektronik, dan perabot rumah). Sedikit sekali yang mau menerima jaminan deposito dan jaminan pribadi (personal guarantee). Beberapa BPRS menyediakan kredit tanpa agunan. Agunan (collateral) bagi BPRS adalah bidang yang tidak dapat diramal oleh manajemen BPRS. Kejadian yang sering dialami oleh BPRS adalah; peminjam menjual jaminan, jaminan rusak dalam kecelakaan atau hilang karena dicuri. Secara internal, mereka juga mengalami kesulitan karena tidak didukung sistem hukum untuk mengeksekusi agunan (lihat tabel III.17).

Seluruh BPRS tidak mempunyai pengalaman dalam melakukan eksekusi jaminan melalui jalur formal karena akan mengeluarkan biaya yang besar dan tidak sebanding dengan nilai yang akan didapat, ditambah lagi membutuhkan waktu yang lama dan pelik karena masih rendahnya penegakan hukum oleh aparat peradilan. Oleh karena itu beberapa BPRS menempuh cara kekeluargaan dalam menyelesaian eksekusi agunan.

Masalah utama yang hadapi oleh manajemen dalam menjalankan operasional BPRS adalah masalah penagihan dan kredit macet, serta persaingan dengan lembaga keuangan lainnya. Masalah kedua terbanyak adalah rendahnya mobilisasi modal dan dana dari masyarakat dan minimnya fasilitas penunjang operasional kantor (lihat tabel III.18).

Seluruh BPRS telah menggunakan perangkat komputer, namun penggunaannya mayoritas hanya terbatas pada kegiatan administrasi dan pelaporan kepada BI. Beberapa 
Tabel III.17 :

Pengalaman dan pendapat tentang mengesekusi jaminan

\begin{tabular}{|c|c|c|}
\hline \multirow{2}{*}{$\begin{array}{l}\text { BPR dgn pengalaman eksekusi } \\
R=\text { Rangking } N=\text { Jumlah BPR }\end{array}$} & \multicolumn{2}{|c|}{ B P R S } \\
\hline & $\mathbf{R}$ & $\mathbf{N}=\mathbf{0}$ \\
\hline Tidak puas: Rendahnya transparansi, terlalu mahal, dan prosedurnya panjang & - & - \\
\hline Puas : Kerjasama yg baik dgn pengadilan dan lembaga pelelangan & - & - \\
\hline Tidak puas : Alasan lainnya & - & - \\
\hline Masih dalam proses & - & - \\
\hline BPR tanpa pengalaman eksekusi & $\mathbf{R}$ & $\mathbf{N}=5$ \\
\hline Tdk Effisien : Terlalu mahal u/ kredit kecil terlalu berbelit-belit dan lama & 1 & 2 \\
\hline Lebih menyukai eksekusi informal bekerja sama dgn debitur & 1 & 2 \\
\hline Tidak ada kredit macet, belum dibutuhkan & - & - \\
\hline Tidak pengalaman, tdk mengerti prosedurnya & - & - \\
\hline Memperburuk citra BPR, dikritik krn terlalu kejam & 2 & 1 \\
\hline
\end{tabular}

BPRS menggunakan program yang mereka kembangkan sendiri dengan perusahaan pemasok perangkat lunak namun belum ada standar baku yang dapat digunakan sebagai acuan pengembangan perangkat lunak (program). Program yang dikembangkan meliputi bidang; akunting, administrasi kredit dan tabungan. BPRS yang menggunakan program

Tabel III.18 :

Masalah Utama yang diungkapkan oleh Direktur BPRS

\begin{tabular}{|c|c|c|}
\hline \multirow{2}{*}{$\begin{array}{c}\text { M a s a l a } \mathrm{h} \\
\mathrm{R}=\text { Rangking } \mathrm{N}=\text { Jumlah BPR }\end{array}$} & \multicolumn{2}{|c|}{ B P R S } \\
\hline & $\mathbf{R}$ & $\mathbf{N}=\mathbf{5}$ \\
\hline \multicolumn{3}{|l|}{ OPERASIONAL } \\
\hline Penagihan dan kredit macet & 1 & 4 \\
\hline Rendahnya mobilisasi dana dan modal & 2 & 3 \\
\hline Persaingan & 1 & 4 \\
\hline Ekspansi kredit, over likuid & - & - \\
\hline Pengambilan dan eksekusi jaminan & - & - \\
\hline Citra BPR buruk dan rendahnya kepercayaan & - & - \\
\hline Kurang Promosi & 3 & 2 \\
\hline Pemilik terlalu banyak sulit menambah modal & 3 & 2 \\
\hline \multicolumn{3}{|l|}{ SDM } \\
\hline Rendahnya kemampuan pegawai & 2 & 3 \\
\hline Rendahnya kualitas pegawai baru & - & - \\
\hline Rendahnya disiplin dan motivasi pegawai & - & - \\
\hline \multicolumn{3}{|l|}{ ORGANISASI } \\
\hline Rendahnya struktur organisasi \& pembagian peg. & 4 & 1 \\
\hline Sedikitnya ruang dan fasilitas kantor & 2 & 3 \\
\hline Akunting yg lemah dan mslh pajak akuntansi & - & - \\
\hline Rendahnya wewenang dan campur tangan phk luar & - & - \\
\hline Tidak effektifnya dewan komisaris & 4 & 1 \\
\hline
\end{tabular}


adalah BPRS yang relatif besar mengingat investasi untuk perangkat lunak dan perangkat keras relatif mahal.

Nampaknya perlu dilakukan standarisasi perangkat lunak yang menyangkut akuntansi yang terintregrasi dengan tabungan, deposito dan perkreditan, karena program tersebut akan sangat membantu manajemen dalam menganalisa dan memudahkan transaksi keuangan lainnya.

\subsubsection{Kebutuhan Pendidikan dan Pelatihan}

Seluruh BPRS menyiapkan anggaran untuk kegiatan pelatihan untuk level direktur, staf pembiayaan (kredit), staf adminitratif dan staf operasional lainnya.

Di level direksi semua BPRS membutuhkan training yang menyangkut manajemen BPRS antara lain: kepemimpinan, perencanaan strategis, dan pengambilan keputusan. Kebutuhan training tersebut dihubungkan dengan beberapa hambatan yang selama ini mereka merasakan bahwa pengelolaan BPRSnya belum maksimal. Jenis training penting lainnya yang teridentifikasi adalah training manajemen resiko, sedangkan topik training hukum, perpajakan, internal kontrol, pemasaran, dan akuntansi jarang peminatnya (lihat tabel III.19).

Tabel III.19 :

Kebutuhan Training bagi Direktur BPRS

\begin{tabular}{|l|c|c|}
\hline \multicolumn{1}{|c|}{$\begin{array}{c}\text { Masalah } \\
\text { R = Rangking N = Jumlah BPR }\end{array}$} & \multicolumn{2}{|c|}{ B P R S } \\
\cline { 2 - 3 } & - & - \\
Tidak membutuhkan Training & 4 & 1 \\
Manajemen BPR, Internal Kontrol & & \\
Manajemen Umum (Syariah), Leadership, & & \\
Perencanaan Strategis \& pengambilan & 1 & 6 \\
Keputusan. & 2 & 3 \\
Manajemen Risiko dan keuangan & 3 & 2 \\
Manajemen Sumber Daya Manusia & 4 & 1 \\
Aspek hukum dan perpajakan & 4 & 1 \\
Pemasaran & 4 & 1 \\
Akuntansi & & - \\
Lainnya : Pendidikan Formal, Ekonomi makro & - & \\
Dan moneter & & \\
\hline
\end{tabular}

Jenis pelatihan yang teridentifikasi bagi staf pembiayaan (kredit) BPRS adalah pelatihan kredit secara umum berikut pengadministrasinya, analisa kredit, penagihan dan penyelamatan kredit (lihat tabel III.20). 
Tabel III.20 :

Kebutuhan Training bagi Staf Pembiayaan BPRS

\begin{tabular}{|l|c|c|}
\hline \multicolumn{1}{|c|}{ Masalah } & \multicolumn{2}{c|}{ B P R S } \\
\cline { 2 - 3 } R = Rangking N= Jumlah BPR & R & N = 6 \\
\hline Tidak membutuhkan Training & - & - \\
Kredit secara umum \& administrasi Training AO & 1 & 4 \\
Analisis Kredit, resiko dan usaha & 2 & 3 \\
Markerting dan custumer relations & - & - \\
Penagihan kredit dan penyelamatan kredit & 3 & 2 \\
Pengawasan dan monitoring kredit & 3 & 2 \\
Aplikasi komputer & 2 & 3 \\
Lainnya: Aspek manajemen BPRS & - & - \\
\hline
\end{tabular}

Tabel III.21 :

Kebutuhan Training bagi Staf BPRS Lainnya

\begin{tabular}{|l|c|c|}
\hline \multicolumn{1}{|c|}{ Masalah } & \multicolumn{2}{c|}{ B P R S } \\
\cline { 2 - 3 } R = Rangking N= Jumlah BPR & R & N = 6 \\
\hline Tidak membutuhkan Training & - & - \\
Analisis keuangan dan manajemen & 4 & 1 \\
Akuntansi & 4 & 1 \\
Perangkat keras dan lunak & - & - \\
Pelaporan umum dan keuangan & 3 & 2 \\
Hubungan dengan nasabah dan pemasaran & 3 & 2 \\
Aspek hukum dan perpajakan & 3 & 2 \\
Penanganan uang palsu & - & - \\
Magang di BPRS lainnya & 2 & 3 \\
Manajemen Oprs. & 1 & 6 \\
Lainnya & - & - \\
\hline
\end{tabular}

Kebutuhan pelatihan bagi staf keuangan dan administrasi lainnya seperti yang tercermin pada tabel tabel III.21 menunjukkan bahwa training yang paling diminati oleh staf keuangan dan administrasi adalah manajemen bank syariah. Mereka menyadari bahwa pengetahuan mereka masih minim dalam pengelolaan bank dengan prinsip syariah karena sampai saat ini penyelenggaraan pelatihan manajemen BPRS sangat jarang diadakan. Mengenai bentuk pelatihan dengan pola magang di bank syariah (BU atau BPR) yang lebih maju ternyata merupakan pola yang menarik. Jenis pelatihan lain yang diharapkan untuk staf keuangan dan administrasi adalah pemasaran, pelaporan, hukum dan perpajakan. 


\section{Kondisi Persaingan}

\subsection{Pelayanan kepada Nasabah}

BPRS menyediakan pelayanan pembiayaan, tabungan dan deposito berjangka kepada para nasabahnya. Selain produk umum tersebut terdapat juga layanan lainnya seperti; asuransi takaful (1 BPRS) dan pemesanan barang (Istina) (1 BPRS).

Semua BPR menyediakan pelayanan tabungan yang memberikan kesempatan/ kebebasan kepada nasabahnya untuk menyetor dan menarik secara harian. Produk tabungan yang ditawarkan relatif lebih beragam yaitu $83 \%$ BPRS mempunyai produk tabungan lebih dari satu jenis dan $17 \%$ BPRS hanya memiliki satu jenis tabungan. Berbeda dengan praktek BPR konvensional yang menetapkan suku bunga, BPRS menerapkan bagi hasil (mudharabah) bagi produk tabungan. Dalam penetapan tingkat bagi hasil tidak ada perbedan yang nyata antar sesama BPRS. Penetapan pembagian keuntungan yang lebih besar bagi nasabah merupakan faktor yang menarik bagi nasabah untuk menabung.

Dalam penetapan besar nisbah bagi hasil, memperhatikan besarnya keuntungan (bunga) yang ditawarkan oleh pesaingnya, seperti BPR konvensional lainnya, dan bank komersial yang beroperasi di wilayahnya. Perbedaan nisbah yang ditawarkan dalam wilayah tertentu dengan wilayah lainnya menunjukan situasi persaingan BPR yang ketat karena di setiap wilayah harus diterapkan strategi yang berbeda untuk menghadapi pesaing yang berbeda.

Ada dua cara BPRS menentukan tingkat bagi hasil tabungan yakni: Pertama, saldo terakhir langsung dikalikan dengan nisbah. Kedua, saldo terakhir langsung dikalikan prosentase (dibobot) tertentu untuk selanjutnya dikalikan dengan nisbah. Prosentase bobot adalah porsi dari nominal rekening tabungan tertentu yang benar-benar dianggap dapat disalurkan kembali oleh bank kepada pihak yang membutuhkannya. Besar prosentase bobot tabungan berkisar antara $80 \%$ s.d 90\%. 50\% BPRS yang beroperasi di Jatim menggunakan sistem pembobotan, $33 \%$ BPRS besar dan $67 \%$ BPRS kecil.

Dua BPRS besar menawarkan tabungan yang tidak dibayar bagi hasil. Tabungan ini dibuka untuk menampung zakat yang diserahkan oleh nasabahnya. Bentuknya dapat berupa tabungan zakat atau hanya berupa rekening penampungan (rekening asnaf). Karena sifatnya adalah zakat (seperti sumbangan) pengelolaan tabungan ini diserahkan kepada bank dan tidak ada bagi hasil.

Seluruh BPRS mempunyai produk deposito dengan berbagai macam jangka waktu, mulai dari satu bulan sampai dengan satu tahun. Deposito yang ditawarkan oleh BPRS secara umum sama dengan bentuk deposito umum BPR konvensional, kecuali bentuk keuntungan yang ditawarkan kepada penyimpan yakni dengan sistem bagi hasil. Nisbah 
Tabel IV.1 :

Aspek pelayanan BPR Syariah

\begin{tabular}{|l|c|}
\hline \multicolumn{1}{|c|}{ Uraian } & BPR Syariah \\
\hline \multicolumn{1}{|c|}{ Jumlah BPR } & 6 \\
Produk tabungan & \\
\% BPR d / 1 produk tabungan & 16,6 \\
\% BPR d > 2 produk tabungan & 83,4 \\
Nisbah rata2 produk utama & $52: 50$ \\
Deposito & \\
\% BPR d / produk deposito & 100,0 \\
Nisbah rata2 produk deposito & $65,2: 34,8$ \\
Produk kredit/pembiayaan & \\
\% BPR d 1-2 produk kredit & 50,0 \\
\% BPR d / 3 produk kredit & 50,0 \\
Rata2 margin terendah & 40,0 \\
Rata2 margin tertinggi & 53,4 \\
Margin rata2 dua produk utama & 6,0 \\
\% produk d / 5 - 27\% & - \\
\% produk d / 30 - 36\% & - \\
\% produk d / 37 - 48\% & 50,0 \\
\% produk d / 51 - 100\% & 50,0 \\
Rata2 jangka waktu paling singkat (bln) & 4,0 \\
Rata2 jangka waktu paling panjang (bln) & 33,0 \\
Jangka waktu kredit pada 2 produk & 6,0 \\
\% produk d / 1 - 3 bulan & - \\
\% produk d / 4 - 10 bulan & 16,7 \\
\% produk d / 12 bulan & 50,0 \\
\% produk d / 18 - 24 bulan & 16,7 \\
\% produk d / 30 - 60 bulan & 16,7 \\
Frekuensi cicilan: & 83,3 \\
\% BPR hanya dgn bulanan saja & 0,0 \\
\% BPR hanya dgn harian dan mingguan & 16,7 \\
\hline Ket: d - dgnanan dan lainnya & \\
\hline
\end{tabular}

Ket: $\mathrm{d} /$ = dgn; margin = bagi hasil pada BPRS;

rata-rata untuk produk deposito dengan jangka waktu satu tahun 65,2\% untuk nasabah dan $34.8 \%$ untuk bank. Seperti juga pada tabungan, 50\% BPRS menggunakan sistem bobot dalam perhitungan pembagian keuntungan, yang besar "bobot" antara 75\% untuk deposito satu bulan sampai dengan 100\% untuk deposito satu tahun. Walaupun BPRS memiliki pasar tersendiri yakni masyarakat yang tidak menghendaki sistem bunga, besar kecilnya nisbah yang ditawarkan kepada masyarakat juga mempertimbangkan tingkat keuntungan (bunga) yang ditawarkan oleh lembaga keuangan lainnya sebagai pesaingnya yang beroperasi di wilayah yang sama. 
Jenis pembiayaan yang paling populer saat ini di BPRS adalah bentuk jual beli dengan mark up yakni Murabahah dan Baiu Bitaman Ajil. Besarnya margin yang dikenakan untuk pembiayaan dengan sistem jual beli dengan mark up adalah terendah $40 \%$ pertahun dan tertinggi 53,4\% pertahun.

Sementara ini pembiayaan dengan bentuk bagi hasil (mudharabah) hampir tidak ada BPRS yang menyalurkannya lagi. Hal ini mungkin disebabkan karena produk ini masih belum begitu populer di masyarakat atau BPRS sangat selektif sekali dalam menyalur pembiayaan mudharabah karena sulit menemukan peminjam yang layak, khususnya yang mempunyai karakter yang betul-betul baik. Outstanding pembiayaan mudharabah adalah pembiayaan lama, dengan kolektibilitas kurang begitu menggembirakan. Ada 50\% BPRS yang menyalurkan jenis pembiayaan mudharabah, dari BPRS yang menyalurkan mudharabah 67\%-nya hanya memiliki 1 rekening pembiayaan mudharabah. Nisbah pembagian keuntungan pembiayaan mudharabah secara rata-rata $56 \%$ untuk peminjam dan $44 \%$ untuk bank.

BPRS menawarkan kepada masyarakat satu jenis pembiayaan tanpa harus membayar margin atau bagi hasil yang disebut pembiayaan Qardhul Hasan. Satu BPRS mempunyai outstanding pembiayaan jenis ini, sedangkan BPRS lainnya belum memiliki dengan alasan belum menemukan calon penerima yang layak. Berhubung jenis pembiayaan ini tidak dikenakan margin atau bagi hasil maka sumber dana diambilkan dari dana yang dihimpun dalam tabungan zakat atau rekening asnaf. Jumlahnya penyalurannya relatif kecil sekali mengingat penyalurannya berasal dari zakat yang disalurkan melalui BPR syariah.

Jangka waktu pembiayaan mayoritas BPRS (murabahah) rata-rata antara empat bulan sampai dengan 33 bulan. Satu BPRS besar mempunyai pembiayaan murabahah dengan jangka waktu terlama 5 tahun (60 bulan). Mayoritas produk pembiayaan yang ditawarkan berjangka waktu 12 bulanan (50\%), dengan cicilan bulanan.

\subsection{Jangkauan Operasional}

Pada sub bab ini akan dijelaskan mengenai jangkauan wilayah BPRS dan menjelaskan nasabah yang dapat dijangkau yakni, jumlah nasabah yang berhasil diraih dalam kegiatan operasional BPRS baik untuk pendanaan maupun pemberian pembiayaan.

\subsubsection{Jangkauan Wilayah}

Sebagai lembaga keuangan yang berorientasi pada masyarakat berpenghasilan kecil di pedesaan, lokasi kantor BPRS berada pada lokasi yang strategis dimana selalu mudah diakses di jalan raya, dekat dengan pasar tradisisonal atau pusat perdagangan. Hal ini dapat dilihat pada tabel IV.2. ternyata bahwa seluruh BPRS berada di ibu kota kecamatan dan di pinggir jalan raya serta sebagian besar $(66,7 \%)$ berlokasi di pasar tradisional atau 
pusat perdagangan. Tidak ada BPRS yang berada di ibukota kabupaten/kotamadya. Bila dilihat dari jarak ke ibukota kotamadya/kabupaten maka rata-rata jarak ke ibukota kotamadya/ kabupaten 16 km. Jarak antara BPRS dengan ibukota kabupaten/kotamadya mayoritas $(83 \%)$ kurang dari $25 \mathrm{KM}$.

Tabel IV.2 :

Jangkauan geografis dan persaingan BPR Syariah

\begin{tabular}{|c|c|}
\hline Uraian & BPR Syariah \\
\hline & 6 \\
\hline \multicolumn{2}{|l|}{$\underline{\text { Lokasi }}$} \\
\hline Jarak Rata2 (Km) ke Ibukota Kab/Kodya & 16,0 \\
\hline \% BPR dalam Ibukota Kab / Kodya & 0,0 \\
\hline \% BPR > 25 km ke Ibukota Kab/Kodya & 16,7 \\
\hline Jarak Rata2 (Km) ke Kecamatan & 0,8 \\
\hline$\%$ BPR di Kecamatan & 100,0 \\
\hline$\% \mathrm{BPR}>5 \mathrm{~km}$ ke kecamatan & 0,0 \\
\hline$\%$ BPR di prs.tradisonal/pusat perdag. & 66,7 \\
\hline$\%$ BPR pada jln utama & 100,0 \\
\hline$\%$ BPR di daerah turis & 0,0 \\
\hline \multicolumn{2}{|l|}{ Langkauan geografis } \\
\hline$\%$ BPR d/ lebih dari 1 kantor & 50,0 \\
\hline Jumlah rata2 kecamatan yang dilayani & 12,4 \\
\hline \% BPR melayani 1 - 4 kecamatan & 0,0 \\
\hline$\%$ BPR melayani => 10 kecamatan & 67,7 \\
\hline \multicolumn{2}{|l|}{ Tabungan pd. kantor pusat BPR di kec.pusat } \\
\hline$\%$ Rata2 jumlah tabungan & 30,0 \\
\hline$\%$ BPR d/ 100\% terkonsentrasi & 0,0 \\
\hline$\%$ BPR d / <50\% terkonsentrasi & 44,2 \\
\hline \multicolumn{2}{|l|}{ Kredit pd. kantor pusat BPR di kec. pusat } \\
\hline \% Rata2 portofolio kredit/pembiayaan & 46,8 \\
\hline$\% \mathrm{BPR} d / 100 \%$ terkonsentrasi & 0,0 \\
\hline$\%$ BPR d / < 50\% terkonsentrasi & 33,4 \\
\hline \multicolumn{2}{|l|}{ Situasi persaingan } \\
\hline \% BPR: yg merasa tdk mempunyai saingan & 0,0 \\
\hline$\%$ BPR: $>2$ pesaing & 100,0 \\
\hline \multicolumn{2}{|l|}{ Lembaga pesaing yg disebutkan: } \\
\hline \% BPR: Bank komersial & 33,4 \\
\hline$\%$ BPR: BRI unit & 83,4 \\
\hline$\%$ BPR: BPR lainnya & 83,4 \\
\hline$\%$ BPR: LDKP & 0,0 \\
\hline \% BPR: Koperasi dan lembaga keu. Lainnya & 83,4 \\
\hline
\end{tabular}

Walaupun BPRS tidak beroperasi di Ibukota kabupaten, namun nasabahnya dapat berasal dari Ibukota kabupaten/kodya. Baik tabungan maupun penyaluran pembiayaan BPRS tidak ada yang terkonsentrasi sepenuhnya di kecamatan tempat kedudukan bank dengan jumlah kecamatan yang dilayani oleh BPRS rata-rata 12,4 kecamatan. 
Tidak dijumpai hubungan antara jarak BPRS ke ibukota kabupaten dengan jumlah asset, namun relatif mempunyai hubungan dengan besar NPL-nya. BPRS yang berjarak 10 KM dari ibukota kabupaten $67 \%$ adalah BPRS kecil dan $33 \%$ adalah BPRS besar. Satu BPRS dengan jarak 20 s.d $30 \mathrm{KM}$ tergolong BPRS besar. BPRS dengan jarak $10 \mathrm{KM}$ dari ibukota kabupaten memiliki NPL yang relatif tinggi, mereka masuk kelas kinerja kredit C dan D. Sementara BPRS dengan jarak 15 KM s.d 30 KM memiliki NPL relatif rendah dengan masuk kelas kinerja kredit A dan B.

Pada tabel VI.2 juga dapat dijelaskan bahwa 50\% BPRS memiliki lebih dari satu kantor bank, 50\% lainnya hanya memiliki satu kantor. BPRS yang memiliki lebih dari satu kantor memiliki asset rata-rata Rp.2.2 milyar, sedangkan BPRS yang hanya memiliki satu kantor saja memiliki asset rata-rata Rp.321 juta. Jumlah kecamatan yang dilayani juga berbanding lurus dengan total asset BPRS. BPRS besar (kelas asset C) rata-rata melayani 17 kecamatan, sedangkan BPRS kecil (kelas asset A) rata-rata melayani 7 kecamatan.

\subsubsection{Jangkauan Nasabah}

BPRS rata-rata memiliki 512 rekening pembiayaan dengan rata-rata baki debet sebesar Rp. 1,8 juta. Jumlah rekening pinjaman per BPRS bervariasi antara 102 - 1496 rekening dengan baki debet rata-rata antara Rp. 553 ribu - Rp. 4,14 juta. Sebanyak 64\% dari rekening pembiayaan adalah baki debet BPRS di bawah Rp.1 juta (lihat tabel VI.3).

Jumlah nasabah yang dilayani berhubungan erat dengan besar asset BPRS yaitu semakin besar asset BPRS maka semakin banyak jumlah nasabahnya dan saldo debetnya. Pada BPRS besar (kelas asset C) rata-rata melayani 945 debitur dengan outstanding ratarata Rp.1,6 juta, sedangkan BPRS kecil (kelas asset A) rata-rata melayani 165 nasabah dengan outstanding rata-rata sebesar Rp.985 ribu.

Dengan mengabaikan BPRS yang NPLnya paling rendah dan baru didirikan, BPRS dengan kinerja paling baik (kelas kredit A) dapat melayani lebih banyak nasabah peminjan (1.496 rekening) dengan rata-rata baki debet yang lebih besar (Rp. 1,2 juta) dibandingkan BPRS dengan kinerja paling buruk (D) yang hanya memiliki 102 nasabah peminjam dengan baki debet rata-rata \pm Rp. 0,6 juta.

Penyaluran pembiayaan BPRS terutama untuk pembiayaan produktif. Pembiayaan modal kerja dan invenstasi mencapai $88 \%$ dari total rekening pembiayaan atau mencapai 97\% dari nominal pembiayaan yang disalurkan. Untuk tujuan konsumsi hanya 5\% dari total rekening atau $2 \%$ dari total nominal. Sektor usaha dominan yang dibiayai adalah sektor perdagangan yang mencapai 77\% dari jumlah baki debet di akhir bulan Desember 1999. Sektor usaha kedua terbanyak yang dilayani adalah pertanian mencapai $12 \%$, sektor jasa $8 \%$, dan industri kecil dan kerajian hanya $4 \%$ masing-masing dari baki debet pembiayaan (lihat tabel III.3). 
Tabel IV.3 :

Konsumen dijangkau BPR Syariah

\begin{tabular}{|c|c|}
\hline Uraian & BPR Syariah \\
\hline & 6 \\
\hline \multicolumn{2}{|l|}{ Portofolio kredit/pembiayaan } \\
\hline Rata-rata jumlah rekening & 512,0 \\
\hline Rata2 \% rekening < Rp. 1 juta & 64,0 \\
\hline Rata2 \% rekening > Rp. 5 juta & 6,4 \\
\hline Rata2 nilai per rekening (Rp.juta) & 1,8 \\
\hline Rata2 \% nilai < Rp. 1 juta & 21,0 \\
\hline Rata2 \% nilai $>$ Rp. 5 juta & 43,2 \\
\hline \multicolumn{2}{|l|}{ Tabungan } \\
\hline Rata-rata rekening & $1.434,0$ \\
\hline Rata2 \% rekening $<$ Rp. 0.5 juta & 89,2 \\
\hline Rata2 \% rekening > Rp. 1 juta & 8,5 \\
\hline Rata2 jlh nilai (Rp. 000) & 354,0 \\
\hline Rata2 \% nilai < Rp. 0.5 juta & 21,0 \\
\hline Rata2 \% nilai > Rp. 1 juta & 71,0 \\
\hline \multicolumn{2}{|l|}{ Deposito } \\
\hline Rata-rata rekening & 26,0 \\
\hline Rata2 \% rekening < Rp. 1 juta & 21,5 \\
\hline Rata2 $\%$ rekening $>$ Rp. 5 juta & 44,3 \\
\hline Rata2 jlh nilai (Rp.juta) & 9,7 \\
\hline Rata2 \% nilai $<$ Rp. 1 juta & 1,7 \\
\hline Rata2 $\%$ nilai $>$ Rp. 5 juta & 91,0 \\
\hline \multicolumn{2}{|l|}{ Pinj. Berdsrkan tujuan/Sektor) } \\
\hline \multicolumn{2}{|l|}{ KMK/Investasi } \\
\hline Rata2 \% rekening & 88,4 \\
\hline Rata2 \% nilai & 96,7 \\
\hline \multicolumn{2}{|l|}{ Konsumsi } \\
\hline Rata2 \% rekening & 4,9 \\
\hline Rata2 \% nilai & 2,1 \\
\hline \multicolumn{2}{|l|}{ Perdagangan } \\
\hline Rata2 \% rekening & 80,3 \\
\hline Rata2 \% nilai & 76,6 \\
\hline \multicolumn{2}{|l|}{ Pertanian } \\
\hline Rata2 \% rekening & 9,7 \\
\hline Rata2 \% nilai & 11,5 \\
\hline \multicolumn{2}{|l|}{ Jasa } \\
\hline Rata2 \% rekening & 5,9 \\
\hline Rata2\% nilai & 8,2 \\
\hline
\end{tabular}

Jumlah rekening tabungan pada BPRS rata-rata adalah 1.424 rekening dengan variasi antara 167 rekening pada BPRS dengan asset paling kecil sampai dengan 3.570 rekening pada BPRS paling besar. Rata-rata nominal tabungan BPRS adalah Rp. 354.074, yang bervariasi dari Rp.54.000 di BPRS dengan asset paling kecil sampai dengan Rp.19,1 juta di BPRS dengan asset paling besar (lihat tabel III.3). 
Sebagian besar rekening tabungan nasabah BPRS adalah yang bersaldo dibawah Rp.500 ribu mencapai $89 \%$ dari total rekening tabungan, namun prosentase nilainya hanya $21 \%$ dari total tabungan. Jika dibandingkan antara nilai tabungan dengan jumlah rekening tabungan bersaldo di atas Rp.1 juta, walaupun prosentase rekeningnya kecil hanya 8,5\% namun prosentase nilainya mencapai $71 \%$ dari total tabungan BPRS.

Produk deposito walaupun agak jarang digunakan tetapi mampu menghimpun dana lebih banyak dari tabungan. BPRS besar khususnya sangat memahami bahwa deposito adalah instrumen utama dalam memobilisasi dana. Semua BPRS menawarkan produk deposito, dengan rata-rata jumlah rekening deposito BPRS adalah 26 rekening, yang bervariasi dari hanya 1 rekening yakni pada BPRS paling buruk kinerjanya sampai dengan 89 rekening deposito pada BPRS dengan asset paling besar. Rata-rata nominal depositonya Rp.9,7 juta (lihat tabel III.3).

Sebagian besar rekening deposito nasabah BPRS adalah bernominal kurang dari Rp.5 juta yang mencapai $44,3 \%$ dari total rekening deposito, dan merupakan $91 \%$ dari total nominal deposito. Jika dibandingkan dengan deposito kurang dari Rp.1 juta prosentase rekeningnya sebesar $21,5 \%$ dengan prosentase nominalnya hanya $1,7 \%$ dari total deposito BPRS.

Produk deposito berjangka adalah faktor yang strategis untuk perkiraan pertumbuhan BPRS. BPRS dengan asset lebih dari Rp.1 milyar sampai dengan Rp.5 milyar berhasil menghimpun tabungan Rp.893,1 juta dari 3.570 penabung. BPRS yang sama dapat menghimpun dana dari deposito sebesar Rp.1,1 milyar dari hanya 89 deposan. BPRS ini mempunyai 18 deposan yang memiliki nominal deposito rata-rata Rp.46 juta. Sebanyak $39 \%$ nasabahnya mendepositokan dananya dengan nominal lebih dari Rp.5 juta yang memberikan sumbangan $91 \%$ terhadap total deposito. BPRS kecil rata-rata hanya mempunyai 7 nasabah dengan nominal deposito rata-rata Rp. 6,2 juta yang merupakan 3 kali lebih rendah dibanding rata-rata deposito BPRS besar.

\subsection{Persaingan}

Berdasarkan hasil survey ternyata tidak terjadi persaingan antar BPRS tetapi justru lembaga keuangan formal dan informal yang sudah lama beroperasi di tempat BPRS yang bersangkutan ternyata jadi pesaing mereka. Alasan yang diungkap dalam persaingan adalah; pertama, masyarakat belum begitu tahu mengenai bank dengan sistem syariah; kedua, masyarakat terbiasa dengan sistem perbankan konvensional dengan bunga menarik; ketiga, lembaga keuangan formal telah lebih dahulu hadir di daerah tempat mereka beroperasi; keempat, pelayanan yang diberikan oleh lembaga pesaing lebih baik; kelima, terdapat lembaga keuangan informal yang juga beroperasi dengan sistem syariah. 
Tabel IV.4 :

Pelayanan dan jangkauan berdasarkan kelas asset

\begin{tabular}{|c|c|c|c|}
\hline & \multicolumn{2}{|c|}{ Kelas Asset } & \multirow{2}{*}{$\begin{array}{l}\text { Total } \\
\text { Syariah }\end{array}$} \\
\hline & $\begin{array}{c}\text { A } \\
\text { BPR Syariah }\end{array}$ & $\begin{array}{c}\text { C } \\
\text { BPR Syariah }\end{array}$ & \\
\hline Jml BPR & 3 & 3 & 6 \\
\hline \multicolumn{4}{|l|}{ Jasa-jasa } \\
\hline \multicolumn{4}{|l|}{ Bunga tabungan $<12 \%$} \\
\hline \multicolumn{4}{|l|}{ Bunga tabungan $>12 \%$} \\
\hline Nisbah Tabungan (BPRS) & $50: 50$ & $50: 50$ & $50: 50$ \\
\hline \multicolumn{4}{|l|}{ Bunga Deposito $<15 \%$} \\
\hline \multicolumn{4}{|l|}{ Bunga Deposito $>15 \%$} \\
\hline Nisbah Deposito (BPRS) & $60: 40$ & $55: 40$ & $58: 42$ \\
\hline \multicolumn{4}{|l|}{ Jangkauan goegrafis } \\
\hline$\% \mathrm{BPR} d />1$ kantor & 0,0 & 100,0 & 50 \\
\hline Rata2 kec. Yg dilayani & 7,7 & 17,0 & 12,4 \\
\hline$\%$ BPR melayani $=>10 \mathrm{kec}$ & 66,7 & 100,0 & 66,7 \\
\hline \multicolumn{4}{|l|}{ Tab. pd. kantor pusat BPR di kec. Pusat } \\
\hline$\%$ BPR d / > 75\% terkons. & 66,6 & 33,4 & 50,0 \\
\hline$\% \mathrm{BPR} d /<50 \%$ terkons. & 0,0 & 66,6 & 33,3 \\
\hline \multicolumn{4}{|l|}{ Kredit pd. kantor pusat BPR di kec. Pusat } \\
\hline$\%$ BPR d / > 75\% terkonsentrasi & 0,0 & 100,0 & 50,0 \\
\hline$\% \mathrm{BPR} d /<50 \%$ terkonsentrasi & 0,0 & 0,0 & 0,0 \\
\hline Tdk ada saingan & 0,0 & 0,0 & 0,0 \\
\hline \multicolumn{4}{|l|}{ Konsumen yg dilayani } \\
\hline Rata2 jml rek. Kredit & 165 & 858 & 512 \\
\hline Rata2 nilai Kredit (Rp. Juta) & 0,2 & 1,5 & 0,8 \\
\hline Rata2 jml rek. Tabungan & 355 & 2.494 & 1424 \\
\hline Rata2 nilai tab. (Rp. 000) & 85.097 & 623.051 & 354.074 \\
\hline Rata2 jml rek. Deposito & 7 & 46 & 26 \\
\hline Rata2 nilai Dep. (Rp.juta) & 41,0 & 610,0 & 326 \\
\hline
\end{tabular}

Mayoritas BPRS menghadapi minimal 3 pesaing utama $(83 \%)$ yakni:

a. Bank Umum (d.h.i BRI-Unit desa dan $\mathrm{KC} / \mathrm{KCP}^{4} \mathrm{BCA}$ ) adalah pesaing dalam menghimpun dana masyarakat karena lebih dahulu beroperasi dan produk yang ditawarkan sangat bersaing, dengan pelayanan yang lebih cepat.

b. BPR konvensional adalah pesaing baik dalam menghimpun dana maupun dalam menyalurkan dana kepada masyarakat.

$4 \mathrm{KC} / \mathrm{KCP}$ adalah kantor cabang dan kantor cabang pembantu 
c. KSP (Koperasi Simpan Pinjam) dan lembaga keuangan informal seperti Baitul Maal Watamwil (BMT) adalah pesaing dalam menghimpun maupun dalam menyalurkan dana kepada masyarakat.

Berdasarkan hasil survey tingkat persaingan terhadap kelas asset dan NPL BPRS dapat diindikasikan bahwa semakin tinggi tingkat persaingan pada BPRS kecil (kelas asset A) semakin kecil NPL, sebaliknya semakin tinggi tingkat tingkat persaingan pada BPRS besar (kelas asset C) semakin besar NPL.

\section{Pengawasan, Perlindungan Simpanan dan Asosiasi BPR}

\subsection{Pengawasan oleh Bank Indonesia}

Dalam sub-bab pengawasan akan diuraikan hal-hal yang berhubungan dengan; pelaksanaan pemeriksaan on-site, jangka waktu, jumlah pemeriksa yang terlibat, dan saran perbaikan tugas pengawasan BPRS oleh Bank Indonesia.

Seluruh BPRS diperiksa kurang dari 1 tahun, kecuali satu BPRS yang baru beroperasi dengan sistem syariah. Hasil survey menunjukan tidak ada hubungan antara volume dan kinerja BPRS dengan frekuensi pemeriksaan (lihat tabel V.1).

Ukuran asset tidak menjadi pertimbangan untuk menentukan banyaknya pemeriksa. Hal ini dapat dimaklumi karena tingkat asset BPRS yang paling besar hanya berada di kelas asset C (Rp.3,077 milyar).

Jumlah pemeriksa pada BPRS dengan kinerja kredit paling buruk (D) sebanyak 3 org dibandingkan dengan 3 kelas lainnya sebanyak 2 orang. BPRS umumnya diperiksa selama 3-4 hari $(60 \%)$, dan diperiksa selama 5-7 hari (40\%).

Lama pemeriksaan tergantung dari besarnya asset BPRS, yakni seluruh BPRS kecil dan 30\% BPRS besar diperiksa 3-4 hari kerja, dan 70\% BPRS besar diperiksa 5-7 hari kerja.

Bank Indonesia memberikan laporan hasil pemeriksaan (LHP) kepada semua BPRS diperiksa. Satu BPRS belum menerima LHP pada saat dilakukan survey.

Sebagaimana terlihat di tabel V.2, rekomendasi difokuskan pada tiga saran perbaikan pengawasan. Saran tertinggi adalah peningkatan kualitas SDM pengawas BI khususnya pemahaman terhadap operasi BPRS. Masih rendahnya pemahaman pengawas BI terhadap BPRS dapat dimaklumi karena sistem syariah relatif baru dikenal. Saran kedua adalah peningkatan frekuensi dan kontinuitas pemeriksaan yakni, antara 1-4 kali setahun. Saran ketiga, BPRS juga membutuhkan adanya bimbingan dan bantuan teknis sebagai kelanjutan dari pemeriksaan on site. 
Tabel V.1

Pengawasan, Pelindungan Simpanan dan Asosiasi

\begin{tabular}{|c|c|}
\hline Uraian & BPR Syariah \\
\hline & 6 \\
\hline \multicolumn{2}{|l|}{ Pengawasan langsung $\mathrm{BI} /$ on-Site supervision } \\
\hline \multicolumn{2}{|l|}{ Terakhir kali dilaksanakan: } \\
\hline$\%$ BPR $<1$ thn yll & 83,3 \\
\hline$\%$ BPR 1-2 thn yll & 0,0 \\
\hline$\%$ BPR $>2$ thn yll & 0,0 \\
\hline Rata2 hari pemeriksaan & 5,0 \\
\hline$\%$ BPR 1-2 hari & 0,0 \\
\hline$\%$ BPR 3-4 hari & 60,0 \\
\hline$\%$ BPR 5-7 hari & 40,0 \\
\hline Rata2 jml pengawas & 2,0 \\
\hline$\%$ BPR 2 pengawas & 80,0 \\
\hline$\%$ BPR 3-4 pengawas & 20,0 \\
\hline Meneriman Laporan hasil pemeriksaan (\% BPR) & 80,0 \\
\hline Publikasi TKS hasil pemeriksaan ( $\%$ BPR Setuju ) & 83,3 \\
\hline \multicolumn{2}{|l|}{ Diaudit oleh accountant public } \\
\hline$\%$ BPR yg blm diaudit & 50,0 \\
\hline$\%$ BPR $<1$ thn yll & 66,7 \\
\hline$\%$ BPR $>1$ thn yll & 33,3 \\
\hline \multicolumn{2}{|l|}{ Perlindungan simpanan/Deposit protection } \\
\hline \multicolumn{2}{|l|}{$\mathrm{U} /$ mengukur keamanan simpanan: } \\
\hline \% BPR yg menekankan pentingnya jaminan simp. & 83,3 \\
\hline$\%$ BPR: asuransi simpanan saja & 0,0 \\
\hline$\%$ BPR: pencegahan saja & 16,7 \\
\hline \% BPR: kombinasi dari kedua di atas & 83,3 \\
\hline \multicolumn{2}{|l|}{ Organisasi asuransi simp.: } \\
\hline$\%$ BPR: Pemerintah & 66,7 \\
\hline$\%$ BPR: Bank Indonesia & 16,7 \\
\hline$\%$ BPR: Institusi khusus & 16,7 \\
\hline$\%$ BPR: Kerjasama BPR & 0,0 \\
\hline \% BPR: BPR dan Pemerintah & 0,0 \\
\hline Siap membayar premi asuransi (\% BPR) & 100,0 \\
\hline \multicolumn{2}{|l|}{ Asosiasi BPR } \\
\hline$\%$ BPR yang menjadi anggota & 100,0 \\
\hline$\%$ BPR: bayaran $\mathrm{u} /$ jasa khusus & 100,0 \\
\hline
\end{tabular}

Satu BPRS mengharapkan BI memberikan masukan secara berkala kepada mereka sebagai hasil evaluasi dari laporan bulanan yang telah disampaikan. Masukan ini akan dipergunakan oleh BPRS untuk merencanakan tindakan yang akan dilaksanakan di masa yang akan datang.

Mereka juga menyatakan bahwa rekomendasi pemeriksaan BI tidak sepenuhnya dapat dilaksanakan karena kurangnya dukungan dari pemilik. Untuk itu disarankan agar BI memantau secara ketat pelaksanaan rekomendasi pemeriksaan.

Seluruh BPRS mendukung publikasi hasil pemeriksaan BI, kecuali satu BPRS (17\%). BPRS yang berkinerja paling buruk dengan tingkat kelas asset kecil mendukung publikasi tingkat kesehatan hasil pemeriksaan. 
Tabel V.2 :

Rekomendasi untuk meningkatkan pengawasan $\operatorname{BPR}(\mathrm{S})$

\begin{tabular}{|c|l|}
\hline $\begin{array}{c}\text { BPR Syariah } \\
6\end{array}$ & \multicolumn{1}{c|}{ Rekomendasi } \\
\hline 3 & Meningkatkan frekuensi dan kontinuitas dari pemeriksaan dan bimbingan. \\
3 & Menambahkan/meningkatkan bimbingan sbg bagian dari on site supervision \\
- & Menidentifikasi dan membantu secara aktif dalam menemukan solusi masalah dijumpai. \\
1 & Memberikan masukan kepada BPR/BPRS baik secara bulanan maupun triwulanan dari Lapbul \\
- & Mengawasi secara ketat pelaksanaan penerapan rekomendasi pengawasan, \\
& termasuk melibatkan pengurus . \\
& Meningkatkan profesionalitas staff (termasuk menambah pengetahuan di bidang operasional \\
& BPR syariah), atau mendelegasikan kepengawas/ akuntan publik \\
\hline
\end{tabular}

Dari 83\% BPRS yang mendukung publikasi hasil pemeriksaan mengemukan alasan antara lain bahwa publikasi hasil pemeriksaan akan meningkatkan kepercayaan masyarakat selaku nasabah potensial, sehingga meningkatkan citra BPRS. Selain itu juga disarankan adanya sistem peringkat BPR termasuk BPRS yang disebarluaskan kepada masyarakat.

Tabel V.3 :

Argumen pro \& kontra publikasi tingkat kesehatan bank

\begin{tabular}{|c|c|}
\hline $\begin{array}{c}\text { BPR Syariah } \\
5\end{array}$ & Argumen PRO \\
\hline $\begin{array}{l}4 \\
5 \\
4 \\
3\end{array}$ & $\begin{array}{l}\text { Memotivasi / menekan BPR untuk secara serius meningkatkan tingkat kesehatannya } \\
\text { Penting } \mathrm{u} \text { / mengiformasikan ke publik karena kesehatan bank adalah faktor penentu } \\
\text { kepercayaan masyarakat. } \\
\text { Memungkinkan perbandingan antar BPR dan pesaingan timbul persaingan sehat } \\
\text { Bank yg sehat membutuhkan keterbukaan, meningkatkan image bagi BPR Sehat. } \\
\text { Jawaban Ya lainya, dlmbentuk rangking BPR; menginformasikan kemajuan dari } \\
\text { bimbingan BI; Ya, hanya u / diinformasikankepada nasabah saja; YA, terhadap laporan } \\
\text { keuangan yang dipublikasi. }\end{array}$ \\
\hline
\end{tabular}

\begin{tabular}{|c|c|}
\hline $\begin{array}{c}\text { BPR Syariah } \\
1\end{array}$ & KONTRA Arguments \\
\hline $\begin{array}{l}1 \\
1 \\
1 \\
1\end{array}$ & $\begin{array}{l}\text { Rahasia dan kebutuhan internal antara BI \& BPR } \\
\text { Menghambat peningkatan kesehatan bagi BPR KS dan TS } \\
\text { Memprovokasi bank untuk di-rush, dan mempengaruhi BPR lainnya. } \\
\text { Umumnya menyebabkan image BPR menjadi negatif } \\
\text { Lainnya: Hasil penilaian BI bisa jadi salah; lebih baik mengenakan sanksi yg berat kpd } \\
\text { BPR non Sehat; Masyarakat desa belum mengerti informasi kesehatan BPR; Laporan } \\
\text { Laba Rugi telah dipublikasikan. }\end{array}$ \\
\hline
\end{tabular}


Adapun alasan BPRS yang menolak publikasi hasil pemeriksaan BPR karena sifatnya sangat rahasia dan seharusnya hanya diketahui oleh BPRS dan Bank Indonesia. Argumen lainnya yang lebih kuat dan saling terkait adalah publikasi ini akan menyebabkan rush yang kemungkinan juga akan membawa dampak negatif terhadap BPRS yang lain.

\subsection{Audit oleh Akuntan Publik}

BPRS yang diaudit oleh akuntan publik adalah 66\% BPRS besar (kelas asset $C$ ), dan $34 \%$ BPR kecil (kelas asset A) (lihat tabel V.4). Untuk BPRS kecil pemeriksaan oleh akuntan

Tabel V.4 :

Pengawasan, Perlindungan Simpanan dan Assosiasi Berdasarkan Asset

\begin{tabular}{|c|c|c|c|}
\hline \multirow{2}{*}{ U r a i a n } & \multicolumn{2}{|c|}{ Kelas Asset } & \multirow{2}{*}{$\begin{array}{c}\text { Total } \\
\text { BPR Syariah }\end{array}$} \\
\hline & A & $\mathrm{C}$ & \\
\hline Jml BPRS & 3 & 3 & 6 \\
\hline \multicolumn{4}{|l|}{ BI Pengawasan lsg (on-Site sup.) } \\
\hline \multicolumn{4}{|l|}{ Terakhir kali dilaksanakan } \\
\hline$\%$ BPR $<1$ thn yll & 100,0 & 100,0 & 100,0 \\
\hline$\%$ BPR 1-2 thn yll & 0,0 & 0,0 & 0,0 \\
\hline$\%$ BPR > 2 thn yll & 0,0 & 0,0 & 0,0 \\
\hline Rata2 hari pemeriksaan & 3,5 & 5,3 & 4,6 \\
\hline \% BPR 1-2 hari & 0,0 & 0,0 & 0,0 \\
\hline$\%$ BPR 3-4 hari & 100,0 & 33,3 & 60,0 \\
\hline \% BPR 5-7 hari & 0,0 & 66,7 & 40,0 \\
\hline Rata2 jml pengawas & 2,5 & 2,0 & 2,2 \\
\hline$\%$ BPR 2 pengawas & 50,0 & 100,0 & 80,0 \\
\hline \% BPR 3-4 pengawas & 50,0 & 0,0 & 20,0 \\
\hline Meneriman LHP (\% BPR) & 100,0 & 66,7 & 83,3 \\
\hline Publikasi TKS hsl pmrksn ( \% BPR Setuju ) & 66,7 & 100,0 & 83,3 \\
\hline \multicolumn{4}{|l|}{ Diaudit oleh accountant public } \\
\hline$\%$ BPR yg blm diaudit & 66,7 & 33,3 & 50,0 \\
\hline$\%$ BPR $<1$ thn yll & 100,0 & 50,0 & 83,3 \\
\hline$\%$ BPR $>1$ thn yll & 0,0 & 50,0 & 16,7 \\
\hline \multicolumn{4}{|l|}{ Perlindungan simpanan } \\
\hline \multicolumn{4}{|l|}{ U/ mengukur keamanan simpanan: } \\
\hline \% BPR yg menekankan pentingnya jmnn simp. & 100,0 & 100,0 & 100,0 \\
\hline$\%$ BPR: asuransi simpanan & 0,0 & 0,0 & 0,0 \\
\hline$\%$ BPR: ukuran pencegahan & 0,0 & 33,3 & 16,7 \\
\hline \% BPR: kombinasi dari keduanya & 100,0 & 66,7 & 83,3 \\
\hline \multicolumn{4}{|l|}{ Pengelola asuransi simp. } \\
\hline \% BPR: Pemerintah & 33,3 & 66,6 & 66,7 \\
\hline \% BPR: Bank Indonesia & 33,3 & 33,3 & 16,7 \\
\hline$\%$ BPR: Institusi khusus & 33,3 & 0,0 & 16,7 \\
\hline$\%$ BPR: Kerjasama antar BPR & 0,0 & 0,0 & 0,0 \\
\hline \% BPR: BPR dan Pemerintah & 0,0 & 0,0 & 0,0 \\
\hline Siap membayar premi asuransi (\% BPR) & 100,0 & 100,0 & 100,0 \\
\hline \multicolumn{4}{|l|}{ Asosiasi BPR } \\
\hline$\%$ BPR yang menjadi anggota & 100,0 & 100,0 & 100,0 \\
\hline \multicolumn{4}{|l|}{ Siap membayar iuran } \\
\hline Rata2 Iuran ang. blnan (Rp.000) & 23,3 & 35,0 & 28,0 \\
\hline \% BPR: bayaran u/ jasa khusus & 100,0 & 100,0 & 100,0 \\
\hline
\end{tabular}


publik hanya terbatas pada pemeriksaan pajak. BPRS yang pernah diperiksa oleh akuntan publik $34 \%$ adalah dengan kinerja baik (kelas kinerja kredit A), sedangkan $66 \%$ berkinerja buruk (kelas kinerja kredit C) (lihat tabel V.5).

\subsection{Perlindungan Simpanan}

Perlindungan simpanan diajukan beberapa alternatif pilihan yang diklasifikasikan menjadi 3 pilihan, yaitu a) memperbaiki perlindungan simpanan melalui asuransi simpanan, b) memperbaiki kualitas SDM dan c) mengurangi risiko kredit dengan menekankan pada

Tabel V.5

Pengawasan, Perlindungan Simpanan dan Asosiasi Berdasarkan kinerja Kredit

\begin{tabular}{|c|c|c|c|c|c|}
\hline \multirow[b]{2}{*}{ Ur a i a n } & \multicolumn{4}{|c|}{ Kelas Kinerja Kredit } & \multirow{2}{*}{$\begin{array}{c}\text { Total } \\
\text { BPR } \\
\text { Sy. }\end{array}$} \\
\hline & $\begin{array}{c}\text { A } \\
\text { BPR Sy. }\end{array}$ & $\begin{array}{c}\text { B } \\
\text { BPR Sy. }\end{array}$ & $\begin{array}{c}\text { C } \\
\text { BPR Sy. }\end{array}$ & $\begin{array}{c}\text { D } \\
\text { BPR Sy. }\end{array}$ & \\
\hline Jml BPR & 2 & 1 & 2 & 1 & 6 \\
\hline \multicolumn{6}{|l|}{ BI on-Site supervision } \\
\hline Terakhir kali dilaksanakan & & & & & \\
\hline$\%$ BPR $<1$ thn yll & 100,0 & 100,0 & 50,0 & 100,0 & 100,0 \\
\hline$\%$ BPR 1-2 thn yll & 0,0 & 0,0 & 50,0 & 0,0 & 0,0 \\
\hline$\%$ BPR > 2 thn yll & 0,0 & 0,0 & 0,0 & 0,0 & 0,0 \\
\hline Rata2 hari pemeriksaan & 5,0 & 4,0 & 4,0 & 4,0 & 4,6 \\
\hline$\%$ BPR 1-2 hari & 0,0 & 0,0 & 0,0 & 0,0 & 0,0 \\
\hline$\%$ BPR 3-4 hari & 50,0 & 100,0 & 50,0 & 100,0 & 60,0 \\
\hline \% BPR 5-7 hari & 50,0 & 0,0 & 0,0 & 0,0 & 40,0 \\
\hline Rata2 jml pengawas & 2,0 & 2,0 & 2,0 & 3,0 & 2,2 \\
\hline$\%$ BPR 2 pengawas & 100,0 & 2,0 & 100,0 & 0,0 & 80,0 \\
\hline$\%$ BPR 3-4 pengawas & 0,0 & 0,0 & 0,0 & 100,0 & 20,0 \\
\hline LHP diterima (\% BPR) & 100,0 & 100,0 & 50,0 & 100,0 & 100,0 \\
\hline Publikasi TKS hsl pemerik. (Setuju \% BPR) & 100,0 & 100,0 & 100,0 & 100,0 & 83,3 \\
\hline \multicolumn{6}{|l|}{ Diaudit o/ akuntan publik } \\
\hline$\%$ BPR yg blm diaudit & 50,0 & 100,0 & 0,0 & 100,0 & 50,0 \\
\hline$\% \mathrm{BPR}<1$ thn yll & 50,0 & 0,0 & 50,0 & 0,0 & 33,3 \\
\hline$\% \mathrm{BPR}>1$ thn yll & 0,0 & 0,0 & 50,0 & 0,0 & 16,7 \\
\hline \multicolumn{6}{|l|}{ Perlindungan simpanan } \\
\hline \multicolumn{6}{|l|}{$\mathrm{U} /$ mengukur keamanan simpanan: } \\
\hline$\%$ BPR yg menekankan & & & & & \\
\hline pentingnya jmnn simp. & 100,0 & 100,0 & 100,0 & 100,0 & 100,0 \\
\hline \% BPR: asuransi simpanan & 0,0 & 0,0 & 0,0 & 0,0 & 0,0 \\
\hline \% BPR: ukuran pencegahan & 50,0 & 0,0 & 0,0 & 0,0 & 16,7 \\
\hline \% BPR: kombinasi dr diatas & 50,0 & 100,0 & 100,0 & 100,0 & 83,3 \\
\hline \multicolumn{6}{|l|}{ Organisasi asuransi simp. } \\
\hline$\%$ BPR: Pemerintah & 100,0 & 0,0 & 50,0 & 100,0 & 66,7 \\
\hline$\%$ BPR: Bank Indonesia & 0,0 & 100,0 & 0,0 & 0,0 & 16,7 \\
\hline$\%$ BPR: Institusi khusus & 0,0 & 0,0 & 50,0 & 0,0 & 16,7 \\
\hline$\%$ BPR: Kerjasama BPR & 0,0 & 0,0 & 0,0 & 0,0 & 0,0 \\
\hline \% BPR: BPR dan Pemerintah & 0,0 & 0,0 & 0,0 & 0,0 & 0,0 \\
\hline Siap membayar premi asuransi (\% BPR) & 100,0 & 100,0 & 100,0 & 100,0 & 100,0 \\
\hline Asosiasi BPR & & & & & \\
\hline$\%$ BPR yg menjadi anggota & 100,0 & 100,0 & 100,0 & 100,0 & 100,0 \\
\hline \multicolumn{6}{|l|}{ Siap membayar iuran } \\
\hline Iuran blnan rata2 (Rp.000) & 35,0 & 0,0 & 22,5 & 25,0 & 28,0 \\
\hline \% BPR: Bayaran u/ jasa khusus & 100,0 & 100,0 & 100,0 & 100,0 & 100,0 \\
\hline
\end{tabular}


analisis kredit dan jaminan. Dua pilihan terakhir dapat dijadikan sarana preventif dalam memperbaiki kinerja dan membatasi kerugian atas penyaluran pembiayaan, serta memberikan perlindungan bagi penghimpunan dana pihak ketiga. Pilihan pertama akan memberikan rasa aman bagi masyarakat penyimpan dana dan memiliki dampak meningkatkan kepercayaan masyarakat.

Sebagian besar BPRS memilih untuk menggunakan gabungan sarana preventif dan asuransi simpanan (83\%). Hanya satu (17\%) BPRS yang menggunakan sarana preventif. Sarana preventif adalah yang berhubungan dengan aspek-aspek perkreditan dan kualitas SDM.

Mayoritas BPRS mengharapkan pemerintah menjadi motor penggerak lembaga penjamin simpanan $(67 \%)$, seperti pelaksanaan jaminan pemerintah yang masih berlaku saat ini. Sedangkan lembaga lain yang diharapkan untuk menjadi motor penggerak lembaga penjaminan adalah Bank Indonesia (17\%) dan lembaga yang dibentuk secara khusus (17\%). Pilihan pemerintah menjadi lembaga ideal ada pada 33\% BPRS kecil dan $67 \%$ BPRS besar.

\subsection{Asosiasi BPR}

Seluruh BPRS menjadi anggota Asbisindo, dan hanya satu yang tidak tergabung dalam Perbarindo. Asbisindo adalah asosiasi yang beranggotakan BPR yang beroperasi berdasarkan prinsip syariah, sedangkan Perbarindo merupakan asosiasi yang beranggotakan BPR tanpa melihat sistem operasi maupun kepemilikan. 80\% direktur BPRS menghendaki iuran bulanan keanggotaan pada Perbarindo dibatasi antara Rp. 20.000 s.d Rp.25.000, namun ada juga BPRS (20\%) bersedia membayar Rp.50.000 perbulan (lihat tabel V.5).

Selain menjadi anggota Perbarindo, BPRS juga tergabung pada Asbisindo (Asosiasi BPR Syariah), dan selaku anggota juga membayar iuran keanggotaan. Mayoritas (60\%) BPRS menghendaki iuran bulanan kepada Asbisindo sebesar Rp.50.000. Satu BPRS menginginkan iuran Rp.25.000 dan satu BPR menginginkan iuran bulanan Rp.200.000,00 dengan alasan bahwa keberadaan BPR dengan sistem syariah relatif masih baru baik di mata masyarakat luas maupun bagi pengelola BPRS. Untuk itu perlu promosi yang dapat dilakukan melalui Asbisindo, seminar, ceramah-ceramah dan pelatihan kepada SDM BPRS, yang kesemuanya itu membutuhkan dukungan dana yang tidak sedikit.

Seluruh BPRS bersedia untuk membayar fee tambahan terhadap jasa tambahan yang kemungkinan akan diberikan oleh asosiasi di masa mendatang. Salah satu fungsi dan jasa yang diharapkan BPRS di masa datang dari asosiasi adalah untuk meningkatkan aktivitasnya dalam bidang pengembangan SDM dengan cara memfasilitasi atau menyediakan pelatihan. Pernyataan ini sesuai dengan fakta di lapangan bahwa kualitas SDM merupakan rintangan utama untuk meningkatkan operasi BPRS. 
Tabel V.6 :

Fungsi dan Jasa yang diharapkan oleh Asosisasi BPR(S)

\begin{tabular}{|c|c|}
\hline $\begin{array}{l}\text { BPR Syariah } \\
6\end{array}$ & Fungsi dan Jasa \\
\hline 6 & $\begin{array}{l}\text { Memfokuskan diri pada Sumber Daya Manusia BPR dengan mengkoordinir / } \\
\text { menyediakan training. }\end{array}$ \\
\hline 6 & Menyediakan jasa konsultasi, khususnya pada BPR yang berkinerja buruk \\
\hline 4 & Mengorganisasikan dan menyalurkan kepentingan dan aspirasi seluruh anggotanya \\
\hline 1 & Menidentifikasi dan memfasilitasi akses terhadap dana murah \\
\hline- & Mengorganisasikan pertukaran informasi melalui media yang beragam \\
\hline 3 & $\begin{array}{l}\text { Mengukung peningkatan image BPR / termasuk mempromosikan BPR syariah (pada } \\
\text { BPR syariah) }\end{array}$ \\
\hline 2 & $\begin{array}{l}\text { Mengembangkan/memfasilitasi bentuk dari lembaga perlidungan/penjaminan } \\
\text { simpanan, atau mendelegasikan kepengawas / akuntan publik }\end{array}$ \\
\hline- & Memfasilitasi kerjasama antar BPR \\
\hline- & Membangun sistem informasi (seperti DKM Bank Indonesia) peminjam-peminjam nakal \\
\hline- & Mengembangkan standar pengajian dan sistem kerja \\
\hline- & Berfungsi sebagai pengawas BPR, menggantikan fungsi pengawasan Bank Indonesia \\
\hline
\end{tabular}

Jasa konsultasi adalah jasa lainnya yang dibutuhkan oleh BPRS. Nampaknya asosiasi BPR di Jawa Timur berhasil menciptakan kesadaran bagi anggotanya untuk memanfaatkan asosiasi tempat berkonsultasi masalah operasional BPRS. Fungsi ketiga yang diharapkan BPRS (4 BPRS) adalah dapat mengorganisasi dan menyalurkan kebutuhan dan aspirasi seluruh anggotanya. Jasa lain yang diharapkan adalah mengidentifikasi dan memfasilitasi anggota untuk mengakses dana murah (lihat tabel V.6).

\section{Kesimpulan dan Saran}

\subsection{Kesimpulan}

\subsubsection{Kondisi Internal}

a. Struktur asset BPRS sebagian besar terdiri dari portofolio pembiayaan sebesar $67 \%$, penempatan pada bank lain sebesar $26 \%$, sedangkan struktur kewajiban terdiri dari deposito sebesar $26 \%$, tabungan sebesar $29 \%$ dan modal disetor sebesar $21 \%$.

b. Pendapatan BPRS terutama berasal dari kegiatan pembiayaan yang disalurkan yakni $88 \%$ dari total pendapatan, sedangkan pengeluaran biaya operasional mencapai $99 \%$ dari total biaya BPRS. Biaya paling banyak yang dikeluarkan BPRS adalah biaya penghimpunan dana yakni sebesar $28 \%$ dari total biaya. 
c. Kebanyakan BPRS tidak dapat memenuhi ketentuan PPAP, sehingga hal ini merupakan masalah serius yang harus segera dibenahi.

d. Penyebab tingkat keuntungan BPRS rendah adalah rendahnya efisiensi, sehingga margin yang diperoleh terlalu kecil. Salah satu bentuk rendahnya efisiensi adalah jumlah pegawai BPRS lebih banyak 2 atau 3 kali lipat dibandingkan dengan BRI unit di wilayah yang sama yang assetnya lebih besar empat kali dari BPRS.

e. Kelebihan likuiditas adalah kondisi yang dialami oleh BPRS besar karena berhasil menghimpun dana dari deposito, namun kesulitan memberikan pembiayaan (kredit) baru. Sebaliknya bagi BPRS kecil mengalami kekurangan modal karena kesulitan dalam memobilisasi dana dari masyarakat.

f. BPRS dengan tingkat kewenangan relatif tinggi berkinerja lebih buruk dibandingkan BPRS yang menikmati kewewenangan tinggi.

g. Pemahaman terhadap fungsi internal kontrol masih beragam, yakni sebagai fungsi pengawasan direktur dan yang lainnya sebagai fungsi pengawasan dari dewan komisaris.

h. BPRS sulit melakukan eksekusi jaminan secara formal sehingga BPRS cenderung menghindari eksekusi jaminan melalui jalur hukum karena biayanya terlalu mahal, tidak efisien, dan kurang transparan. BPRS lebih menyukai eksekusi jaminan dilakukan secara kekeluargaan karena prosesnya lebih cepat dan tidak banyak mengeluarkan biaya.

i. Pemahaman BPRS mengenai manajemen likuiditas belum baik yakni dengan menganggap manajemen likuiditas adalah rasio likuiditas yang digunakan dalam rasio CAMEL dan penempatkan dana likuid sebesar prosentase tertentu pada bank lain. Hanya $33 \%$ manajemen BPR yang memahami manajemen likuiditas dengan benar dengan melaksanakan maturity profile.

j. Faktor yang menyebabkan kredit macet adalah faktor eksternal, seperti kegagalan usaha dan karakter dari debitur yang menyebabkan kredit macet, dan faktor internal seperti ketidakmampuan dalam melakukan analisis yang baik, kurang dipenuhinya prosedur pemberian kredit yang baik dan kurang atau tidak ada agunan tambahan. Mayoritas BPR tidak memiliki standar penghapusan kredit macet (write off). BPR kecil tidak melakukan write-off, karena mengharapkan masih akan dibayar di samping itu kecilnya pembentukan PPAP.

k. Kebutuhan pelatihan mencakup berbagai aspek operasional BPR, mulai dari level direksi sampai dengan staf operasional. Tetapi pelatihan yang dilakukan selama ini belum membawa perbaikan operasional secara secara berarti. 


\subsubsection{Persaingan}

a. Masalah kekurangan modal dan kelebihan likuiditas dikarenakan rendahnya orientasi pasar BPRS dan kurangnya promosi dapat diatasi dengan jiwa kewirausahaan, pengembangan produk, dan pemasaran yang baik.

b. Prosedur yang berbelit-belit dan panjang merupakan masalah utama dalam penyaluran kredit BPRS dan di lain pihak lembaga keuangan pesaing dapat menawarkan layanan lebih cepat.

\subsubsection{Pengawasan}

a. Terbatasnya jumlah dan kurangnya kemampuan pengawas BI dalam bidang operasional BPRS.

b. Pengelolaan aktiva produktif belum sesuai dengan ketentuan yang berlaku, seperti pemenuhan PPAP, dan penghapusan kredit macet.

\subsection{Saran}

\subsubsection{Prioritas Kebijakan}

a. Peraturan perbankan agar diterapkan dengan tegas sehingga dapat membersihkan BPRSBPRS yang sudah tidak dapat disehatkan kembali. Menguatkan industri BPRS antara lain melalui sistem perlindungan simpanan dan pemberdayaan asosiasi BPR akan sulit dilaksanakan jika BPR-BPR yang tidak sehat tidak dibersihkan. Oleh karena itu dibutuhkan tindakan yang cepat dan tepat untuk lebih menjadikan industri BPRS sehat, dapat tumbuh secara berkelanjutan, memiliki citra yang baik, dan dapat duduk sebanding dengan BPR konvensional.

b. Mendukung peningkatkan lembaga keuangan mikro bukan bank dan konversi ke BPRS untuk mengisi gap pasar keuangan di tingkat pedesaan yaitu dengan memperjelas status hukum dan peraturan operasional yang pasti sehingga memungkinkan lembaga keuangan mikro seperti BMT, BKD dan LDKP dapat mengembangkan diri serta memperluas wilayah pelayanan di tingkat pedesaan. Diharapkan juga lembaga keuangan mikro bukan bank dapat meningkatkan statusnya menjadi BPR apabila operasionalnya makin berkembang dan memenuhi persyaratan menjadi BPR, atau sebaliknya.

\subsubsection{Bantuan Teknis yang Diprioritaskan}

a. Mengembangkan sistem pelatihan manajemen untuk meningkatkan kemampuan lembaga BPR. Untuk itu diperlukan beberapa persiapan yang menyangkut materi, tenaga pelatih yang baik, dan evaluasi terhadap dampak pelatihan yang dikemas dalam bentuk 
sistem pelatihan dengan melibatkan asosiasi BPR. Dengan adanya monitoring tersebut diharapkan pelatihan yang dilakukan dapat diperbaiki dari waktu ke waktu dengan tujuan akhir adalah meningkatkan kemampuan lembaga BPR.

b. Mengembangkan sistem konsultasi manajemen yang dapat mendukung pengembangan BPRS melalui asosiasi BPR. Konsultasi manajemen melalui asosiasi tersebut memiliki dua keuntungan. Pertama, BPR mengharapkan asosiasi BPR memberikan pelatihan bagi SDMnya dan bantuan teknis di mana mereka bersedia membayar jasa konsultasi yang diberikan. Kedua, menguatkan asosiasi BPR dengan mengembangkan manajemen konsultasi.

c. Mendukung peningkatan efisiensi melalui komputerisasi kerena dapat menggantikan pekerjaan operasional semi manual dan memperpendek waktu pengerjaan pelaporan. Oleh sebab itu, komputerisasi harus menjadi bagian dari rencana pengembangan kelembagaan BPRS.

\subsubsection{Prioritas Pengawasan}

a. Konsentrasi pemeriksaan hendaknya pada BPR yang kurang sehat dan tidak sehat, serta perlu peningkatan kemampuan pengawas mengenai operasional BPRS.

b. Berkaitan dengan CAMEL, disarankan untuk lebih meningkatkan pembobotan pada KAP dan pemenuhan PPAP. 
Tabel II.1a :

Klasifikasi Sampel BPR Konvesional dan Syariah Di Jawa Timur

\begin{tabular}{|c|c|c|c|}
\hline & $\begin{array}{c}\text { Jml BPR } \\
\text { Konv. }\end{array}$ & $\begin{array}{c}\text { BPR } \\
\text { Konv. }\end{array}$ & BPRS \\
\hline Jml BPR & 115 & 72 & 6 \\
\hline \multicolumn{4}{|l|}{ Tipe BPR } \\
\hline$\%$ BPR Sebelum Pakto 88 & 15,0 & 11,1 & 100,0 \\
\hline \% BPR Setelah Pakto 88 & 80,0 & 76,4 & 0,0 \\
\hline$\%$ BPR Ex-LDKP & 20,0 & 12,5 & 0,0 \\
\hline \multicolumn{4}{|l|}{ Status Hukum } \\
\hline$\%$ Perusahaan Terbatas & 77,0 & 68,0 & 100,0 \\
\hline$\%$ Perusahaan Daerah & 27,0 & 18,1 & 0,0 \\
\hline$\%$ Koperasi & 11,0 & 13,9 & 0,0 \\
\hline \multicolumn{4}{|l|}{ Tahun Beroperasi } \\
\hline Rata2 beroperasi & 115,0 & 8,4 & 4,0 \\
\hline$\%$ BPR 1 -3 tahun & 26,0 & 19,5 & 17,0 \\
\hline$\%$ BPR 5 -9 tahun & 70,0 & 65,3 & 83,0 \\
\hline$\%$ BPR 10 thn dan lebih & 19,0 & 15,3 & 0,0 \\
\hline \multicolumn{4}{|l|}{ Asset } \\
\hline Rata2 (Rp. milyar) & 115,0 & 3,8 & 1,2 \\
\hline$\%$ BPR < Rp.500 juta & 29,0 & 26,4 & 50,0 \\
\hline \% BPR Rp.500 - < 1 Milyar & 29,0 & 23,6 & 0,0 \\
\hline \% BPR Rp.1 - Rp.5 Milyar & 36,0 & 31,9 & 50,0 \\
\hline$\%$ BPR > Rp.5 Milyar & 21,0 & 18,1 & 0,0 \\
\hline \multicolumn{4}{|l|}{$\%$ Portofolio kredit/Asset } \\
\hline Prosentase $\%$ & 115,0 & 68,0 & 67,0 \\
\hline$\% \mathrm{BPR}<60 \%$ & 35,0 & 30,6 & 50,0 \\
\hline$\% \mathrm{BPR}>85 \%$ & 29,0 & 23,6 & 17,0 \\
\hline \multicolumn{4}{|l|}{$\underline{\text { Rata-rata outstanding kredit }}$} \\
\hline Rata2 (Rp. juta) & 115,0 & 3,4 & 1,6 \\
\hline$\%$ BPR $<$ Rp 1 juta & 29,0 & 18,1 & 33,0 \\
\hline$\%$ BPR > Rp.2 juta & 45,0 & 36,1 & 17,0 \\
\hline \multicolumn{4}{|l|}{$\%$ Kredit Non Lancar } \\
\hline Rata2 $(\%)$ & 115,0 & 15,8 & 18,0 \\
\hline$\% \mathrm{BPR}<10 \%$ & 55,0 & 51,4 & 50,0 \\
\hline$\% \mathrm{BPR}>25 \%$ & 29,0 & 23,6 & 17,0 \\
\hline
\end{tabular}

Keterangan:

Angka prosentase pd BPR konvensional prosentase di jatim thd jumlah BPR kolom sampel, sedangkan BPRS nilai baris dibandingkan dengan total BPRS di Jatim 
Table II.2a :

Variasi Assets, Portofolio Kredit dan Kualitas Aktiva Kredit dari BPR Konvensional dan Syariah di Jawa Timur per Desember 1999

\begin{tabular}{|l|c|c|}
\hline & $\begin{array}{c}\text { BPR } \\
\text { Konvensional }\end{array}$ & $\begin{array}{c}\text { BPR } \\
\text { Syariah }\end{array}$ \\
\hline Jumlah BPR & 422 & 6 \\
Jumlah Kantor & 453 & 10 \\
Asset *) & & 1.240 \\
Rata-rata Asset (Rp. Jutaan) & 1.672 & 50,0 \\
$\%$ BPR < Rp. 1 Milyar & 56,1 & - \\
$\%$ BPR > Rp. 5 Milyar & 5,1 & - \\
$\%$ BPR-LDKP < Rp.1 Milyar & 100 & 64 \\
Portofolio Kredit/Asset *) & & 17 \\
Rata-rata \% & 70,5 & 17 \\
$\%$ BPR < 50\% & 18,1 & 67 \\
$\%$ BPR > 85\% & 20,5 & 18 \\
Rata2 kredit/rata2 asset (\%) & 68 & 50 \\
Kredit Non performing *) & & 17 \\
\% Rata-rata & & \\
\% BPR < 10\% $>25 \%$ & 19,1 & \\
\hline
\end{tabular}

*) dgn 414 BPR konvensional selisih 8 BPR dikeluarkan krn Dicabut dan atau akan dicabut izin usahanya untuk BPRS dari masing-masing individu BPRS 
Tabel III.1a :

Neraca Gabungan berdasarkan Kelas Asset (dlm Rp. Juta)

\begin{tabular}{|c|c|c|c|c|c|c|c|c|c|c|}
\hline \multirow{3}{*}{ U r a i a n } & \multicolumn{8}{|c|}{ Asset Class } & \multirow{2}{*}{\multicolumn{2}{|c|}{ Total }} \\
\hline & \multicolumn{2}{|c|}{ A } & \multicolumn{2}{|c|}{ B } & \multicolumn{2}{|l|}{$\mathrm{C}$} & \multicolumn{2}{|l|}{ D } & & \\
\hline & BPR Konv. & BPRS & BPR Konv. & BPRS & BPR Konv. & BPRS & BPR Konv. & BPRS & BPR Konv. & BPRS \\
\hline Jml BPR & 29 & 3 & 29 & 0 & 36 & 3 & 21 & 0 & 115 & 6 \\
\hline$\underline{\text { ASSETS }}$ & & & & & & & & & & \\
\hline Kas & 147,9 & 25,9 & 358,4 & - & $1.428,0$ & 37,9 & $3.137,1$ & - & $5.071,4$ & 63,8 \\
\hline$A B A / B I$ & 935,8 & 93,5 & $4.426,2$ & - & $21.629,2$ & $1.813,4$ & $66.918,6$ & - & $93.909,9$ & $1.906,9$ \\
\hline Portofolio kredit & $6.544,4$ & 488,3 & $13.102,1$ & - & $61.206,9$ & $4.526,0$ & $182.473,3$ & - & $263.326,6$ & $5.014,3$ \\
\hline Lancar $(\%)$ & 80,9 & 83,7 & 78,8 & - & 89,3 & 92,2 & 87,6 & - & 87,4 & 88,0 \\
\hline Kurang Lancar (\%) & 6,2 & 4,4 & 4,8 & - & 3,3 & 3,2 & 3,6 & - & 3,7 & 3,8 \\
\hline Diragukan (\%) & 6,8 & 11,3 & 9,4 & - & 4,6 & 4,4 & 4,6 & - & 4,8 & 7,9 \\
\hline Macet $(\%)$ & 6,0 & 0,7 & 7,0 & - & 2,9 & 0,2 & 4,2 & - & 4,1 & 0,5 \\
\hline (-) PPAP & $(185,2)$ & $(9,3)$ & $(587,9)$ & - & $(2.071,8)$ & $(152,5)$ & $(2.377,9)$ & - & $(5.222,8)$ & $(161,8)$ \\
\hline Asset Tetap & $1.256,3$ & 151,4 & $2.122,1$ & - & $8.053,9$ & 180,2 & $15.395,6$ & - & $26.828,0$ & 331,6 \\
\hline (-) Penyusutan & $(427,3)$ & $(30,1)$ & $(646,9)$ & - & $(3.444,0)$ & $(100,4)$ & $(5.735,4)$ & - & $(10.253,6)$ & $(130,6)$ \\
\hline Asset lainnya & 389,3 & 245,7 & 815,9 & - & $4.138,0$ & 170,0 & $7.324,7$ & - & $12.667,8$ & 415,8 \\
\hline TOTAL ASSETS & $8.661,2$ & 965,4 & $19.589,9$ & - & $90.940,2$ & $6.474,6$ & $267.136,0$ & - & $386.327,4$ & $7.439,9$ \\
\hline \multicolumn{11}{|l|}{ HUTANG/LIABILITIES } \\
\hline Hutang Lancar & 49,7 & 2,6 & 105,6 & - & 606,1 & 25,1 & $2.270,1$ & - & $3.031,5$ & 27,6 \\
\hline Tabungan & $2.108,4$ & 260,2 & $4.939,9$ & - & $25.990,7$ & $1.869,2$ & $44.679,4$ & - & $77.718,4$ & $2.129,4$ \\
\hline Deposito & $1.163,2$ & 116,8 & $3.138,9$ & - & $27.132,7$ & $1.830,4$ & $184.502,2$ & - & $215.937,1$ & $1.947,2$ \\
\hline ABP/BI/kredit & $1.424,4$ & 12,1 & $3.678,9$ & - & $14.276,1$ & $1.127,0$ & $8.473,2$ & - & $27.852,7$ & $1.139,0$ \\
\hline Kewajiban lainnya & 226,3 & 6,2 & 687,7 & - & $2.007,9$ & 57,4 & $7.119,9$ & - & $10.041,9$ & 63,6 \\
\hline \multicolumn{11}{|l|}{ EQUITY } \\
\hline Modal disetor & $3.121,9$ & 619,5 & $4.815,4$ & - & $11.770,5$ & 921,8 & $11.745,2$ & - & $31.453,0$ & $1.541,3$ \\
\hline Modal Lainnya & 487,5 & 16,8 & 117,9 & - & $1.335,5$ & 98,6 & 675,0 & - & $2.615,9$ & 115,4 \\
\hline Cadangan & 339,8 & 0,0 & 464,2 & - & $4.032,4$ & 185,0 & $7.093,5$ & - & $11.930,0$ & 185,0 \\
\hline \multicolumn{11}{|l|}{$L A B A / R U G I$} \\
\hline Akumulasi & $(521,9)$ & $(50,8)$ & $(738,5)$ & - & $(317,8)$ & 21,1 & $(3.309,5)$ & - & $(3.410,8)$ & $(29,7)$ \\
\hline Thn berjalan & 261,8 & $(18,0)$ & 902,9 & - & $4.106,0$ & 339,1 & $3.887,0$ & - & $9.157,7$ & 321,1 \\
\hline TOTAL PASIVA & $8.661,2$ & 965,4 & $19.589,9$ & - & $90.940,0$ & $6.474,6$ & $267.136,0$ & - & $386.327,4$ & $7.439,9$ \\
\hline Tunai/Asset & $2 \%$ & $3 \%$ & $2 \%$ & - & $2 \%$ & $1 \%$ & $1 \%$ & - & $1 \%$ & $1 \%$ \\
\hline ABA/Asset & $11 \%$ & $10 \%$ & $23 \%$ & - & $24 \%$ & $28 \%$ & $25 \%$ & - & $24 \%$ & $26 \%$ \\
\hline Kredit/Asset & $76 \%$ & $51 \%$ & $67 \%$ & - & $67 \%$ & $70 \%$ & $68 \%$ & - & $68 \%$ & $67 \%$ \\
\hline Akt.Tetap bersih/Ass & $10 \%$ & $13 \%$ & $8 \%$ & - & $5 \%$ & $1 \%$ & $4 \%$ & - & $4 \%$ & $3 \%$ \\
\hline TAB/Passiva & $24 \%$ & $27 \%$ & $25 \%$ & - & $29 \%$ & $29 \%$ & $17 \%$ & - & $20 \%$ & $29 \%$ \\
\hline DEP/Passiva & $13 \%$ & $12 \%$ & $16 \%$ & - & $30 \%$ & $28 \%$ & $69 \%$ & - & $56 \%$ & $26 \%$ \\
\hline MDL Disetor/Pass & $36 \%$ & $64 \%$ & $25 \%$ & - & $13 \%$ & $14 \%$ & $4 \%$ & - & $8 \%$ & $21 \%$ \\
\hline Laba (Ak/current)/Pass & $-3 \%$ & $-7 \%$ & $1 \%$ & - & $4 \%$ & $6 \%$ & $0 \%$ & - & $1 \%$ & $4 \%$ \\
\hline
\end{tabular}


Tabel III.2a :

Neraca Gabungan berdasarkan kelas kredit non lancar (dlm juta)

\begin{tabular}{|c|c|c|c|c|c|c|c|c|c|c|}
\hline \multirow{3}{*}{ Ura $\mathbf{r}$ a n } & \multicolumn{8}{|c|}{ Asset Class } & \multirow{2}{*}{\multicolumn{2}{|c|}{ Tot a 1}} \\
\hline & \multicolumn{2}{|c|}{ A } & \multicolumn{2}{|c|}{ B } & \multicolumn{2}{|l|}{ C } & \multicolumn{2}{|l|}{ D } & & \\
\hline & BPR Konv. & BPRS & BPR Konv. & BPRS & BPR Konv. & BPRS & BPR Konv. & BPRS & BPR Konv. & BPRS \\
\hline$J m l B P R$ & 40 & 2 & 15 & 1 & 31 & 2 & 29 & 1 & 115 & 6 \\
\hline ASSETS & & & & & & & & & & \\
\hline Kas & $2.224,2$ & 9,4 & 329,1 & 20,2 & $1.125,4$ & 23,4 & $1.392,7$ & 10,6 & $5.071,4$ & 63,8 \\
\hline$A B A / B I$ & $51.886,7$ & 210,5 & $3.130,5$ & 373,6 & $26.564,7$ & $1.307,8$ & $12.328,0$ & 15,0 & $93.909,9$ & $1.906,9$ \\
\hline Fotofolio kredit & $145.830,0$ & $1.995,7$ & $22.996,6$ & $1.048,5$ & $50.323,9$ & $1.913,6$ & $44.176,1$ & 56,4 & $263.326,6$ & $5.014,3$ \\
\hline Lancar $(\%)$ & 98,7 & 99,8 & 92,9 & 93,5 & 80,9 & 83,3 & 54,9 & 32,1 & 87,4 & 77,2 \\
\hline $\mathrm{KL}(\%)$ & 0,4 & 0,2 & 2,6 & 4,0 & 5,2 & 5,9 & 13,4 & 11,0 & 3,7 & 5,3 \\
\hline $\mathrm{D}(\%)$ & 0,6 & 0,0 & 3,7 & 2,1 & 9,7 & 10,7 & 14,4 & 51,3 & 4,8 & 16,0 \\
\hline Macet $(\%)$ & 0,3 & 0,0 & 0,8 & 0,4 & 4,1 & 0,3 & 17,3 & 5,7 & 4,1 & 1,6 \\
\hline (-) PPAP & $(1.505,5)$ & $(112,2)$ & $(1.099,7)$ & $(16,3)$ & $(1.882,2)$ & $(32,7)$ & $(735,4)$ & $(0,6)$ & $(5.222,8)$ & $(161,8)$ \\
\hline Asset Tetap & $7.710,2$ & 115,0 & $2.155,6$ & 37,3 & $9.011,7$ & 157,2 & $7.950,4$ & 22,1 & $26.828,0$ & 331,6 \\
\hline (-) Penyusutn & $(3.621,0)$ & $(10,4)$ & $(822,0)$ & $(16,0)$ & $(3.643,4)$ & $(93,7)$ & $(2.167,2)$ & $(10,5)$ & $(10.253,6)$ & $(130,6)$ \\
\hline Asset lainnya & $5.027,0$ & 219,5 & 633,8 & 19,4 & $4.973,8$ & 158,0 & $2.033,3$ & 18,8 & $12.667,8$ & 415,8 \\
\hline TTL ASSETS & $207.551,7$ & $2.427,5$ & $27.323,9$ & $1.466,8$ & $86.473,8$ & $3.433,8$ & $64.977,9$ & 111,9 & $386.327,4$ & $7.439,9$ \\
\hline \multicolumn{11}{|l|}{ LIABILITIES } \\
\hline Htg Lancar & $2.237,5$ & 6,5 & 75,3 & 0,7 & 515,1 & 20,5 & 203,7 & 0,0 & $3.031,5$ & 27,6 \\
\hline Tabungan & $35.636,3$ & 895,9 & $7.617,3$ & 207,3 & $28.107,1$ & 975,3 & $6.357,8$ & 50,9 & $77.718,4$ & $2.129,4$ \\
\hline Deposito & $123.176,2$ & 501,8 & $9.425,4$ & 343,0 & $30.145,8$ & $1.101,7$ & $53.189,6$ & 0,8 & $215.937,1$ & $1.947,2$ \\
\hline ABA/BI/loans & $12.205,6$ & 341,3 & $3.715,8$ & 685,7 & $5.904,3$ & 100,0 & $6.027,0$ & 12,1 & $27.852,7$ & $1.139,0$ \\
\hline Kewajiban lainnya & $5.941,9$ & 29,9 & 685,8 & 21,3 & $2.038,1$ & 10,3 & $1.375,7$ & 2,1 & $10.041,9$ & 63,6 \\
\hline \multicolumn{11}{|l|}{ EQUITY } \\
\hline Modal disetor & $11.285,4$ & 577,9 & $2.931,3$ & 155,0 & $12.150,4$ & 714,6 & $5.084,9$ & 93,7 & $31.453,0$ & $1.541,3$ \\
\hline Modal Lainnya & $1.005,5$ & 0,0 & 225,0 & 0,0 & $1.044,8$ & 113,6 & 340,6 & 1,8 & $2.615,9$ & 115,4 \\
\hline Cadangan & $3.309,3$ & 25,7 & 777,0 & 0,0 & $2.861,1$ & 159,3 & $4.982,6$ & 0,0 & $11.930,0$ & 185,0 \\
\hline \multicolumn{11}{|l|}{ LABA/RUGI } \\
\hline Akumulasi & $4.070,3$ & 0,0 & 577,6 & 21,1 & $1.428,9$ & $(0,3)$ & $(9.487,7)$ & $(50,5)$ & $(3.410,8)$ & $(29,7)$ \\
\hline Thn berjalan & $8.683,5$ & 48,6 & $1.292,5$ & 32,8 & $2.277,9$ & 238,8 & $(3.096,1)$ & 0,9 & $9.157,7$ & 321,1 \\
\hline LIABILITIES & & & & & & & & & & \\
\hline \& EQUITY & $207.551,7$ & $2.427,5$ & $27.323,9$ & $1.466,8$ & $86.473,8$ & $3.433,8$ & $64.977,9$ & 111,9 & $386.327,4$ & $7.439,9$ \\
\hline Kas/Asset & $1 \%$ & $0 \%$ & $1 \%$ & $1 \%$ & $1 \%$ & $1 \%$ & $2 \%$ & $10 \%$ & $1 \%$ & $1 \%$ \\
\hline ABAEBI/Asset & $25 \%$ & $9 \%$ & $11 \%$ & $25 \%$ & $31 \%$ & $38 \%$ & $19 \%$ & $13 \%$ & $24 \%$ & $26 \%$ \\
\hline Kredit/Asset & $70 \%$ & $82 \%$ & $84 \%$ & $71 \%$ & $58 \%$ & $56 \%$ & $68 \%$ & $50 \%$ & $68 \%$ & $67 \%$ \\
\hline Akt.tetap/Asset & $2 \%$ & $4 \%$ & $5 \%$ & $1 \%$ & $6 \%$ & $2 \%$ & $9 \%$ & $10 \%$ & $4 \%$ & $3 \%$ \\
\hline ABP/Passiva & $6 \%$ & $14 \%$ & $14 \%$ & $47 \%$ & $7 \%$ & $3 \%$ & $9 \%$ & $11 \%$ & $7 \%$ & $15 \%$ \\
\hline Tab/Passiva & $17 \%$ & $37 \%$ & $28 \%$ & $14 \%$ & $33 \%$ & $28 \%$ & $10 \%$ & $46 \%$ & $20 \%$ & $29 \%$ \\
\hline Dep/Passiva & $59 \%$ & $21 \%$ & $34 \%$ & $23 \%$ & $35 \%$ & $32 \%$ & $82 \%$ & $1 \%$ & $56 \%$ & $26 \%$ \\
\hline Mdl dstr/Pass & $5 \%$ & $24 \%$ & $11 \%$ & $11 \%$ & $14 \%$ & $21 \%$ & $8 \%$ & $84 \%$ & $8 \%$ & $21 \%$ \\
\hline LR/Passiva & $7 \%$ & $3 \%$ & $7 \%$ & $4 \%$ & $4 \%$ & $7 \%$ & $-19 \%$ & $-108 \%$ & $1,5 \%$ & $3,9 \%$ \\
\hline
\end{tabular}

Kredit non lancar: A: $<5 \%$, B: $5-<10 \%$, C: $10-25 \%$, D: $>25 \%$ 
Gambar III.1a :

Struktur Neraca Rata-Rata

BPR Konvensional dan Syariah

\begin{tabular}{|r|r|r|r|r|r|}
\hline \multicolumn{7}{|c|}{ Kelas Asset A } \\
\hline Pos Nrc & Konv & Syariah & Pos Nrc & Konv & Syariah \\
\hline Kas & $2 \%$ & $4 \%$ & Tb \& Dp & $37 \%$ & $40 \%$ \\
ABA & $11 \%$ & $11 \%$ & ABP / BI & $15 \%$ & $4 \%$ \\
Pembiayaan & $73 \%$ & $54 \%$ & Equity & $53 \%$ & $37 \%$ \\
& & & Profit & $-9 \%$ & $-16,0 \%$ \\
\hline
\end{tabular}

\begin{tabular}{|r|r|r|r|r|r|}
\hline \multicolumn{6}{|c|}{ Kelas Kinerja Kredit A } \\
\hline Pos Nrc & Konv & Syariah & Pos Nrc & Konv & Syariah \\
\hline Kas & $2 \%$ & $1 \%$ & Tb \& Dp & $58 \%$ & $52 \%$ \\
ABA & $10 \%$ & $8 \%$ & ABP / BI & $12 \%$ & $9 \%$ \\
Pembiayaan & $79 \%$ & $62 \%$ & Equity & $19 \%$ & $38 \%$ \\
& & & Profit & $7 \%$ & $5 \% *$ \\
\hline
\end{tabular}

\begin{tabular}{|r|c|r|r|r|r|}
\hline \multicolumn{6}{|c|}{ Kelas Asset B } \\
\hline Pos Nrc & Konv & Syariah & Pos Nrc & Konv & Syariah \\
\hline Kas & $2 \%$ & & Tb \& Dp & $42 \%$ & \\
ABA & $21 \%$ & & ABP $/$ BI & $18 \%$ & \\
Pembiayaan & $66 \%$ & & Equity & $29 \%$ & \\
& & & Profit & $7 \%$ & \\
\hline
\end{tabular}

\begin{tabular}{|r|r|r|r|r|r|}
\hline \multicolumn{5}{|c|}{ Kelas Kinerja Kredit B } \\
\hline Pos Nrc & Konv & Syariah & Pos Nrc & Konv & Syariah \\
\hline Kas & $2 \%$ & $1 \%$ & Tb \& Dp & $49 \%$ & $38 \%$ \\
ABA & $10 \%$ & $25 \%$ & ABP/BI & $16 \%$ & $47 \%$ \\
Pembiayaan & $79 \%$ & $71 \%$ & Equity & $24 \%$ & $14 \%$ \\
& & & Profit & $9 \%$ & $4 \%$ \\
\hline
\end{tabular}

\begin{tabular}{|r|r|r|r|r|r|}
\hline \multicolumn{6}{|c|}{ Kelas Asset C } \\
\hline Pos Nrc & Konv & Syariah & Pos Nrc & Konv & Syariah \\
\hline Kas & $2 \%$ & $1 \%$ & Tb \& Dp & $57 \%$ & $54 \%$ \\
ABA & $22 \%$ & $25 \%$ & ABP / BI & $17 \%$ & $23 \%$ \\
Pembiayaan & $67 \%$ & $73 \%$ & Equity & $19 \%$ & $22 \%$ \\
& & & Profit & $4 \%$ & $5 \%$ \\
\hline
\end{tabular}

\begin{tabular}{|r|r|r|r|r|r|}
\hline \multicolumn{6}{|c|}{ Kelas Kinerja Kredit C } \\
\hline Pos Nrc & Konv & Syariah & Pos Nrc & Konv & Syariah \\
\hline Kas & $2 \%$ & $2 \%$ & Tb \& Dp & $52 \%$ & $49 \%$ \\
ABA & $25 \%$ & $26 \%$ & ABP/BI & $13 \%$ & $2 \%$ \\
Pembiayaan & $61 \%$ & $68 \%$ & Equity & $27 \%$ & $23 \%$ \\
& & & Profit & $7 \%$ & $6 \%$ \\
\hline
\end{tabular}

\begin{tabular}{|r|r|r|r|r|r|}
\hline \multicolumn{5}{|c|}{ Kelas Asset D } \\
\hline Pos Nrc & Konv & Syariah & Pos Nrc & Konv & Syariah \\
\hline Kas & $2 \%$ & & Tb \& Dp & $80 \%$ & \\
ABA & $27 \%$ & & ABP /BI & $5 \%$ & \\
Pembiayaan & $65 \%$ & & Equity & $8 \%$ & \\
& & & Profit & $4 \%$ & \\
\hline
\end{tabular}

\begin{tabular}{|r|r|r|r|r|r|}
\hline \multicolumn{6}{|c|}{ Kelas Kinerja Kredit D } \\
\hline Pos Nrc & Konv & Syariah & Pos Nrc & Konv & Syariah \\
\hline Kas & $2 \%$ & $10 \%$ & Tb \& Dp & $47 \%$ & $46 \%$ \\
ABA & $21 \%$ & $13 \%$ & ABP / BI & $20 \%$ & $11 \%$ \\
Pembiayaan & $64 \%$ & $50 \%$ & Equity & $42 \%$ & $41 \%$ \\
& & & Profit & $-13 \%$ & $-44 \%$ \\
\hline
\end{tabular}

\begin{tabular}{|r|c|c|c|c|r|}
\hline \multicolumn{7}{|c|}{ BPR di Jatim } \\
\hline Pos Nrc & Konv & Syariah & Pos Nrc & Konv & Syariah \\
\hline Kas & $2 \%$ & $3 \%$ & Tb \& Dp & $50 \%$ & $47 \%$ \\
ABA & $21 \%$ & $18 \%$ & ABP /BI & $17 \%$ & $13 \%$ \\
Pembiayaan & $67 \%$ & $64 \%$ & Equity & $29 \%$ & $30 \%$ \\
& & & Profit & $0.1 \%$ & $\left.3 \%{ }^{* *}\right)$ \\
\hline
\end{tabular}

*) BPR syariah hasil konversi dan beroperasi kurang dari 1 tahun dikeluarkan dari perhitungan

**) BPR syariah yang mengalami masalah struktural dikeluarkan dari perhitungan 
Tabel III.3a :

Laporan Laba Rugi berdasarkan Kelas Asset (Rp.juta)

\begin{tabular}{|c|c|c|c|c|c|c|c|c|c|c|}
\hline \multirow{3}{*}{ Ura i a n } & \multicolumn{8}{|c|}{ Asset Class } & \multirow{2}{*}{\multicolumn{2}{|c|}{ Tot a 1}} \\
\hline & \multicolumn{2}{|c|}{ A } & \multicolumn{2}{|c|}{ B } & \multicolumn{2}{|l|}{$\mathrm{C}$} & \multicolumn{2}{|l|}{ D } & & \\
\hline & BPR Konv. & BPRS & BPR Konv. & BPRS & BPR Konv. & BPRS & BPR Konv. & BPRS & BPR Konv. & BPRS \\
\hline Jumlah BPR & 29 & 3 & 29 & 0 & 36 & 3 & 21 & & 115 & 6 \\
\hline INCOME & & & & & & & & & & \\
\hline Bunga bank & 266,8 & 26,3 & 987,1 & - & $6.145,6$ & 125,9 & $12.934,0$ & - & $20.333,5$ & 152,2 \\
\hline Pdptn kredit & $2.355,5$ & 99,0 & $4.829,7$ & - & $22.678,7$ & $1.418,2$ & $49.765,9$ & - & $79.629,9$ & $1.517,3$ \\
\hline Pdptn oprs. Lainnya & 174,4 & 0,8 & 309,6 & - & $1.348,2$ & 17,2 & $2.777,4$ & - & $4.609,7$ & 18,0 \\
\hline Pdptn oprs. total & $2.796,8$ & 130,8 & $6.126,5$ & - & $30.172,5$ & $1.561,4$ & $65.477,3$ & - & $104.573,0$ & 1692, \\
\hline Pdptn non oprs. & 14,1 & 22,9 & 48,2 & - & 819,3 & 7,8 & 875,7 & - & $1.757,4$ & 30,7 \\
\hline TOTAL INCOME & $2.810,9$ & 153,7 & $6.174,6$ & - & $30.991,8$ & $1.569,2$ & $66.353,0$ & - & $106.330,4$ & $1.722,9$ \\
\hline BIAYA & & & & & & & & & & \\
\hline Bga u/ BI/bank lain & 261,2 & 0,0 & 870,7 & - & $2.475,6$ & 212,6 & $2.408,1$ & - & $6.015,6$ & 212,6 \\
\hline Bunga kpd nasabah & 503,0 & 25,0 & $1.157,4$ & - & $9.848,2$ & 363,1 & $37.687,7$ & - & $49.196,3$ & 388,1 \\
\hline Biaya pegawai & 877,1 & 71,8 & $1.667,4$ & - & $5.698,9$ & 298,5 & $7.672,3$ & - & $15.916,0$ & 370,3 \\
\hline Penghapusan & 158,4 & 30,5 & 207,4 & - & $1.096,6$ & 160,1 & $1.375,1$ & - & $2.837,5$ & 190,5 \\
\hline Biaya oprs. Lainnya & 696,6 & 32,2 & $1.138,2$ & - & $5.970,8$ & 171,3 & $10.198,9$ & - & $18.004,5$ & 203,5 \\
\hline Biaya oprs. Total & $2.496,3$ & 159,4 & $5.041,1$ & - & $25.090,2$ & $1.205,6$ & $59.342,0$ & - & $91.969,5$ & $1.365,1$ \\
\hline Biaya non oprsl. & 25,5 & 10,2 & 52,9 & - & 909,9 & 4,6 & 457,4 & - & $1.445,7$ & 14,8 \\
\hline TOTAL BIAYA & $2.521,8$ & 169,7 & $5.093,9$ & - & $26.000,1$ & $1.210,2$ & $59.799,4$ & - & $93.425,2$ & 1.379 .8 \\
\hline LABA/RUGI & & & & & & & & & & \\
\hline Sblm pajak & 289,1 & $(16,0)$ & $1.080,7$ & - & $4.991,8$ & 358,9 & $6.553,7$ & - & $12.915,2$ & 34,0 \\
\hline Setelah pajak & 261,8 & $(18,0)$ & 904,3 & - & $4.120,3$ & 355,5 & $3.895,1$ & - & $9.181,4$ & 325,9 \\
\hline Bungabank & $9 \%$ & $18 \%$ & $16 \%$ & - & $20 \%$ & $8 \%$ & $19 \%$ & - & $19 \%$ & $9 \%$ \\
\hline Pedapatan kredit & $84 \%$ & $66 \%$ & $78 \%$ & - & $73 \%$ & $90 \%$ & $75 \%$ & - & $75 \%$ & $88 \%$ \\
\hline Pendaptan oprs lain & $6 \%$ & $1 \%$ & $5 \%$ & - & $4 \%$ & $1 \%$ & $4 \%$ & - & $4 \%$ & $1 \%$ \\
\hline Pdptn non Opsr. & $1 \%$ & $15 \%$ & $1 \%$ & - & $3 \%$ & $0 \%$ & $1 \%$ & - & $2 \%$ & $2 \%$ \\
\hline Bunga ke BI/Bank & $10 \%$ & $0 \%$ & $17 \%$ & - & $10 \%$ & $18 \%$ & $4 \%$ & - & $6 \%$ & $15 \%$ \\
\hline Bunga kpd nasabah & $20 \%$ & $15 \%$ & $23 \%$ & - & $38 \%$ & $30 \%$ & $63 \%$ & - & $53 \%$ & $28 \%$ \\
\hline Bya. Pegawai & $35 \%$ & $42 \%$ & $33 \%$ & - & $22 \%$ & $25 \%$ & $13 \%$ & - & $17 \%$ & $27 \%$ \\
\hline Penghapusan & $6 \%$ & $18 \%$ & $4 \%$ & - & $4 \%$ & $13 \%$ & $2 \%$ & - & $3 \%$ & $14 \%$ \\
\hline Biaya oprs. Lainnya & $28 \%$ & $19 \%$ & $22 \%$ & - & $23 \%$ & $14 \%$ & $17 \%$ & - & $19 \%$ & $15 \%$ \\
\hline Total Biaya & $99 \%$ & $94 \%$ & $99 \%$ & - & $97 \%$ & $100 \%$ & $99 \%$ & - & $98 \%$ & $99 \%$ \\
\hline Biaya Non Oprs. & $1 \%$ & $6 \%$ & $1 \%$ & - & $3 \%$ & $0 \%$ & $1 \%$ & - & $2 \%$ & $1 \%$ \\
\hline
\end{tabular}


Tabel III.4a :

Laporan Laba Rugi berdasarkan Kelas Kredit Non Lancar (Rp juta)

\begin{tabular}{|c|c|c|c|c|c|c|c|c|c|c|}
\hline \multirow{3}{*}{ Urai a n } & \multicolumn{8}{|c|}{ Kinerja Kredit } & \multirow{2}{*}{\multicolumn{2}{|c|}{ Tot a 1}} \\
\hline & \multicolumn{2}{|c|}{ A } & \multicolumn{2}{|c|}{ B } & \multicolumn{2}{|l|}{ C } & \multicolumn{2}{|l|}{ D } & & \\
\hline & BPR Konv. & BPRS & BPR Konv. & BPRS & BPR Konv. & BPRS & BPR Konv. & BPRS & BPR Konv. & BPRS \\
\hline Jumlah BPR & 40 & 2 & 15 & 1 & 31 & 2 & 29 & 1 & 115 & 6 \\
\hline \multicolumn{11}{|l|}{ PENDAPATAN } \\
\hline Bunga bank & $10.111,3$ & 15,1 & 934,9 & 5,0 & $6.389,8$ & 132,1 & $2.897,5$ & 0,0 & $20.333,5$ & 152,2 \\
\hline Pdptn kredit & $37.367,9$ & 570,5 & $9.378,6$ & 255,9 & $18.539,4$ & 677,3 & $14.343,9$ & 13,6 & $79.629,9$ & $1.517,3$ \\
\hline Pdptn opsl lain & $1.370,2$ & 2,0 & 663,9 & 15,3 & 846,2 & 0,7 & $1.729,5$ & 0,0 & $4.609,7$ & 18,0 \\
\hline Ttl pdptn oprsl & $48.849,3$ & 592,3 & $10.977,4$ & 276,2 & $25.775,4$ & 810,1 & $18.970,9$ & 13,6 & $104.573,0$ & $1.692,2$ \\
\hline Ttl pdpt non oprs & 443,2 & 0,0 & 552,8 & 0,0 & 452,5 & 12,5 & 308,9 & 18,3 & $1.757,4$ & 30,7 \\
\hline \multicolumn{11}{|l|}{ PENDAPATAN } \\
\hline TOTAL & $49.292,6$ & 592,3 & $11.530,2$ & 276,2 & $26.227,9$ & 822,6 & $19.279,8$ & 31,8 & $106.330,4$ & $1.722,9$ \\
\hline \multicolumn{11}{|l|}{ BIAYA } \\
\hline Bunga kpd BI/bank & $2.792,1$ & 85,0 & 790,8 & 78,7 & $1.549,7$ & 49,0 & 883,0 & 0,0 & $6.015,6$ & 212,6 \\
\hline Bunga kpd Nasabah & $21.180,5$ & 156,2 & $3.000,7$ & 54,5 & $10.269,7$ & 174,7 & $14.745,5$ & 2,6 & $49.196,3$ & 388,1 \\
\hline Biaya pegawai & $6.149,4$ & 104,9 & $1.913,9$ & 49,2 & $5.255,8$ & 199,0 & $2.596,5$ & 17,2 & $15.916,0$ & 370,3 \\
\hline Penghapusan & 953,1 & 103,2 & 754,1 & 20,6 & 903,7 & 61,7 & 226,5 & 5,1 & $2.837,5$ & 190,5 \\
\hline Bya oprsl lainnya & $6.488,9$ & 74,9 & $2.782,0$ & 37,0 & $4.954,7$ & 87,1 & $3.778,8$ & 4,5 & $18.004,5$ & 203,5 \\
\hline Total biaya Operasional & $37.564,1$ & 524,2 & $9.241,5$ & 240,0 & $22.933,6$ & 571,5 & $22.230,3$ & 29,4 & $91.969,5$ & $1.365,1$ \\
\hline Biaya non Operasional & 357,9 & 3,0 & 663,1 & 0,0 & 376,2 & 10,3 & 48,5 & 1,5 & $1.445,7$ & 14,8 \\
\hline BIAYA TOTAL & $37.922,0$ & 527,2 & $9.904,6$ & 240,0 & $23.309,8$ & 581,8 & $22.278,8$ & 30,9 & $93.425,2$ & $1.379,9$ \\
\hline \multicolumn{11}{|l|}{ LABA/RUGI } \\
\hline Sebelum pajak & $11.370,6$ & 65,0 & $1.625,6$ & 36,2 & $2.918,1$ & 240,8 & $(2.999,1)$ & 0,9 & $12.915,2$ & 343,0 \\
\hline Setelah pajak & $8.683,5$ & 65,0 & $1.295,2$ & 21,1 & $2.297,9$ & 238,8 & $(3.095,1)$ & 0,9 & $9.181,4$ & 325,9 \\
\hline Bungabank & $21 \%$ & $3 \%$ & $8 \%$ & $2 \%$ & $24 \%$ & $16 \%$ & $15 \%$ & $0 \%$ & $19 \%$ & $9 \%$ \\
\hline Pedapatan kredit & $76 \%$ & $97 \%$ & $81 \%$ & $93 \%$ & $71 \%$ & $82 \%$ & $74 \%$ & $43 \%$ & $75 \%$ & $88 \%$ \\
\hline Pendaptan oprs lain & $3 \%$ & $0 \%$ & $5 \%$ & $6 \%$ & $3 \%$ & $0 \%$ & $9 \%$ & $0 \%$ & $4 \%$ & $1 \%$ \\
\hline Pdptn non Opsr. & $1 \%$ & $0 \%$ & $6 \%$ & $0 \%$ & $2 \%$ & $2 \%$ & $2 \%$ & $57 \%$ & $2 \%$ & $2 \%$ \\
\hline Bunga ke BI/Bank & $7 \%$ & $16 \%$ & $8 \%$ & $33 \%$ & $7 \%$ & $8 \%$ & $4 \%$ & $0 \%$ & $6 \%$ & $15 \%$ \\
\hline Bunga kpd nasabah & $56 \%$ & $30 \%$ & $30 \%$ & $23 \%$ & $44 \%$ & $30 \%$ & $66 \%$ & $8 \%$ & $53 \%$ & $28 \%$ \\
\hline Bya. Pegawai & $16 \%$ & $20 \%$ & $19 \%$ & $20 \%$ & $23 \%$ & $34 \%$ & $12 \%$ & $56 \%$ & $17 \%$ & $27 \%$ \\
\hline Penghapusan & $3 \%$ & $20 \%$ & $8 \%$ & $9 \%$ & $4 \%$ & $11 \%$ & $1 \%$ & $16 \%$ & $3 \%$ & $14 \%$ \\
\hline Biaya oprs. Lainnya & $17 \%$ & $14 \%$ & $28 \%$ & $15 \%$ & $21 \%$ & $15 \%$ & $17 \%$ & $15 \%$ & $19 \%$ & $15 \%$ \\
\hline Total Biaya & $99 \%$ & $99 \%$ & $93 \%$ & $100 \%$ & $98 \%$ & $98 \%$ & $100 \%$ & $95 \%$ & $98 \%$ & $99 \%$ \\
\hline Biaya Non Oprs. & $1 \%$ & $1 \%$ & $7 \%$ & $0 \%$ & $2 \%$ & $2 \%$ & $0 \%$ & $5 \%$ & $2 \%$ & $1 \%$ \\
\hline
\end{tabular}

Kredit non lancar: A: $<5 \%$, B: $5-<10 \%$, C: $10-25 \%$, D: $>25 \%$ 
Gambar III.2a :

Struktur Pendapatan dan Ongkos Rata-Rata BPR Konvensional dan Syariah

\begin{tabular}{|c|c|c|c|c|c|}
\hline \multicolumn{6}{|c|}{ Kelas Asset A } \\
\hline Pos L/R & Konv & Syariah & Pos L/R & Konv & Syariah \\
\hline Bunga & & & Bya. & & \\
\hline Bank & $10 \%$ & $28 \%$ & pendanaan & $27 \%$ & $13 \%$ \\
\hline Pend. & & & Bya. Opr & & \\
\hline Kredit & $83 \%$ & $50 \%$ & lainnnya*) & $81 \%$ & $81 \%$ \\
\hline
\end{tabular}

\begin{tabular}{|r|c|c|r|c|c|}
\hline \multicolumn{7}{|c|}{ Kelas Kinerja Kredit A } \\
\hline Pos L/R & Konv & Syariah & Pos L/R & Konv & Syariah \\
\hline Bunga & & & Bya. & & \\
Bank & $19 \%$ & $36 \%$ & $\begin{array}{r}\text { pendanaan } \\
\text { Bya. Opr }\end{array}$ & $46 \%$ & $31 \%$ \\
Pend. & & $62 \%$ & lainnnya*) & $53 \%$ & $67 \%$ \\
Kredit & $77 \%$ & $62 \%$ & \\
\hline
\end{tabular}

\begin{tabular}{|r|l|l|r|r|r|}
\hline \multicolumn{5}{|c|}{ Kelas Asset B } \\
\hline Pos L/R & Konv & Syariah & Pos L/R & Konv & Syariah \\
\hline Bunga & & & Bya. & & \\
Bank & $16 \%$ & & $\begin{array}{r}\text { pendanaan } \\
\text { Bya. Opr }\end{array}$ & $37 \%$ & \\
Pend. & & & lainnnya*) & $62 \%$ & \\
Kredit & $79 \%$ & & & \\
\hline
\end{tabular}

\begin{tabular}{|r|r|r|r|c|c|}
\hline \multicolumn{6}{|c|}{ Kelas Kinerja Kredit B } \\
\hline Pos L/R & Konv & Syariah & Pos L/R & Konv & Syariah \\
\hline Bunga & & & Bya. & & \\
Bank & $6 \%$ & $2 \%$ & $\begin{array}{r}\text { pendanaan } \\
\text { Bya. Opr }\end{array}$ & $33 \%$ & $56 \%$ \\
Pend. & & $93 \%$ & lainnnya*) & $64 \%$ & $44 \%$ \\
Kredit & $86 \%$ & 94 & \\
\hline
\end{tabular}

\begin{tabular}{|c|c|c|c|c|c|}
\hline \multicolumn{6}{|c|}{ Kelas Asset C } \\
\hline Pos L/R & Konv & Syariah & Pos L/R & Konv & Syariah \\
\hline Bunga & & & Bya. & & \\
\hline Bank & $22 \%$ & $6 \%$ & pendanaan & $48 \%$ & $49 \%$ \\
\hline Pend. & & & Bya. Opr & & \\
\hline Kredit & $72 \%$ & $91 \%$ & lainnnya*) & $50 \%$ & $51 \%$ \\
\hline
\end{tabular}

\begin{tabular}{|c|c|c|c|c|c|}
\hline \multicolumn{6}{|c|}{ Kelas Kinerja Kredit C } \\
\hline Pos L/R & Konv & Syariah & Pos L/R & Konv & Syariah \\
\hline Bunga & & & Вуа. & & \\
\hline Bank & $20 \%$ & $14 \%$ & pendanaan & $45 \%$ & $31 \%$ \\
\hline Pend. & & & Bya. Opr & & \\
\hline Kredit & $74 \%$ & $83 \%$ & lainnnya*) & $54 \%$ & $65 \%$ \\
\hline
\end{tabular}

\begin{tabular}{|r|l|r|r|r|r|}
\hline \multicolumn{5}{|c|}{ Kelas Asset D } \\
\hline Pos L/R & Konv & Syariah & Pos L/R & Konv & Syariah \\
\hline Bunga & & & Bya. & & \\
Bank & $24 \%$ & & $\begin{array}{r}\text { pendanaan } \\
\text { Bya. Opr }\end{array}$ & $65 \%$ & \\
Pend. & & & lainnnya*) & $34 \%$ & \\
Kredit & $72 \%$ & & lainna & \\
\hline
\end{tabular}

\begin{tabular}{|r|r|r|r|r|r|}
\hline \multicolumn{5}{|c|}{ Kelas Kinerja Kredit D } \\
\hline Pos L/R & Konv & Syariah & Pos L/R & Konv & Syariah \\
\hline Bunga & & & Bya. & & \\
Bank & $20 \%$ & $0 \%$ & $\begin{array}{r}\text { pendanaan } \\
\text { Bya. Opr }\end{array}$ & $42 \%$ & $8 \%$ \\
Pend. & & & lainnnya*) & $58 \%$ & $87 \%$ \\
Kredit & $73 \%$ & $43 \%$ & \\
\hline
\end{tabular}

\begin{tabular}{|r|c|c|r|c|c|}
\hline \multicolumn{7}{|c|}{ BPR di Jatim } \\
\hline Pos L/R & Konv & Syariah & Pos L/R & Konv & Syariah \\
\hline Bunga & & & Bya. & & \\
Bank & $19 \%$ & $17 \%$ & $\begin{array}{r}\text { pendanaan } \\
\text { Bya. Opr } \\
\text { Pend. }\end{array}$ & $44 \%$ & $31 \%$ \\
Kredit & $74 \%$ & $71 \%$ & lainnnya & $54 \%$ & $66 \%$ \\
\hline
\end{tabular}

*) Biaya operasional lainnya termasuk biaya penghapusan kredit macet. 
Tabel III.5a :

Kelas Asset terhadap Indikator Terpilih

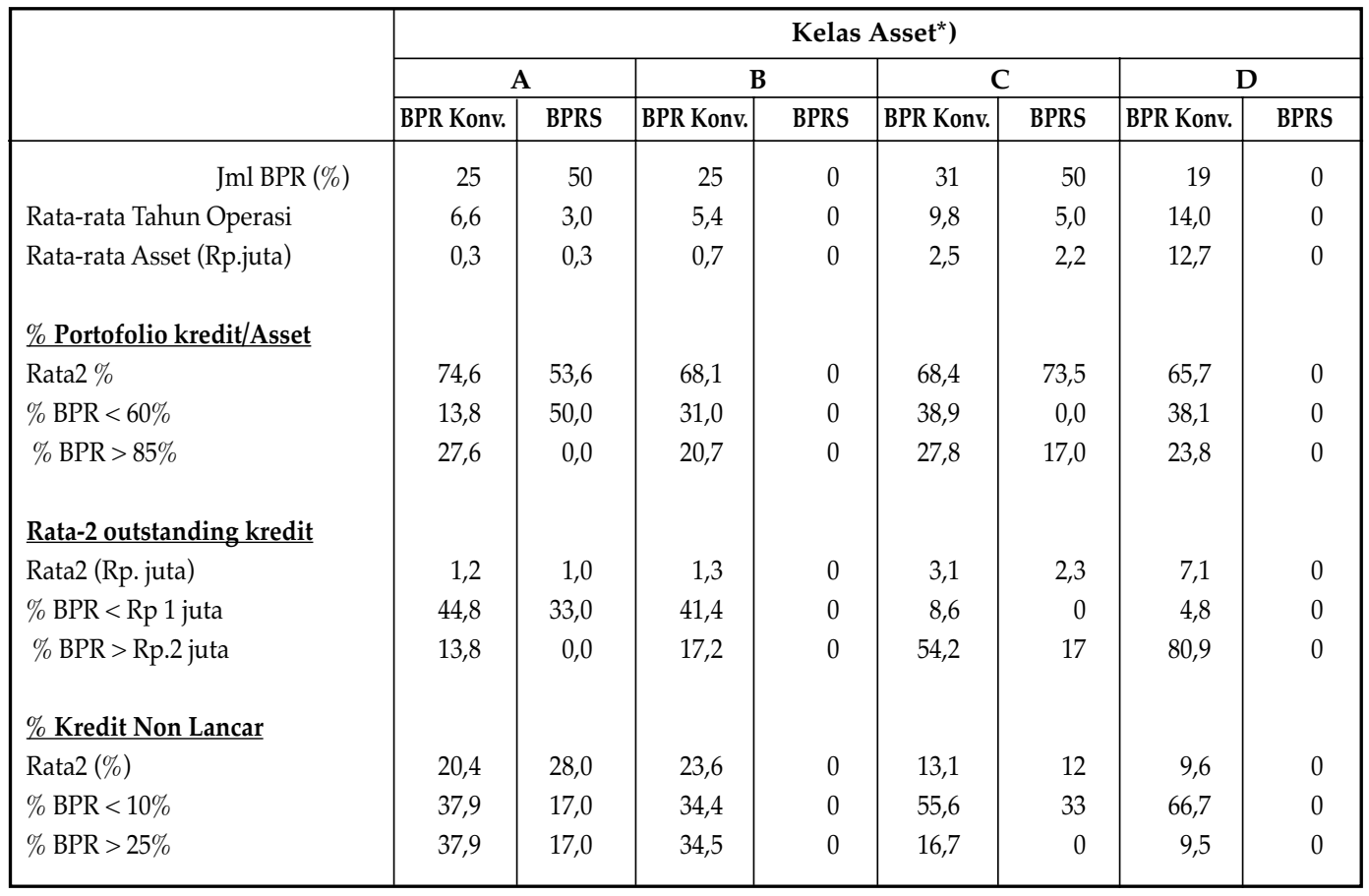

\section{Keterangan:}

_ ${ }^{*}$ ) Dlm klasifikasi asset BPR konvensional jumlah BPR klasifikasikan berjumlah 115 BPR, yg beroperasi di Jatim, Bali dan NTB.

- A: < Rp.500 juta; B: 500 - < Rp.1 M; C: Rp.1 M - Rp.5 M, D: > Rp.5 M 
Tabel III.6a :

Kepemilikan BPR dan Pegawai BPR Konvesional dan Syariah Di Jawa Timur

\begin{tabular}{|c|c|c|c|}
\hline & $\begin{array}{l}\text { Jml sampel } \\
\text { BPR Konv. }\end{array}$ & $\begin{array}{l}\text { BPR Konv.* } \\
\text { di Jatim }\end{array}$ & BPRS $\left.^{* *}\right)$ \\
\hline Jml BPR & 115 & 72 & 6 \\
\hline \multicolumn{4}{|l|}{ Kepemilikan } \\
\hline Rata-rata pemegang saham & 115 & 7,9 & 57,0 \\
\hline$\%$ BPR dgn 1 pemegang saham & 10 & 9,7 & 0,0 \\
\hline$\%$ BPR dgn 2 pemegang saham & 36 & 25,0 & 0,0 \\
\hline$\%$ BPR dgn 3-5 pemegang shm & 42 & 38,9 & 16,7 \\
\hline$\%$ BPR dgn >5 pemegang shm & 27 & 26,4 & 83,3 \\
\hline Rata2 jmlh BPR dgn pgm shm >50\% & 114 & 4,1 & 0,0 \\
\hline \multicolumn{4}{|l|}{ Dewan komisaris } \\
\hline$\%$ BPR dgn 1 org komisaris & 3 & 2,8 & 0,0 \\
\hline$\%$ BPR dgn 2 org komisaris & 57 & 51,4 & 16,7 \\
\hline$\%$ BPR dgn $>2$ org komisaris & 54 & 45,8 & 83,3 \\
\hline \multicolumn{4}{|l|}{ Pengalaman di perbankan } \\
\hline$\%$ rata2 dari komisaris & 114 & 29,7 & 19,2 \\
\hline Jumlah komisaris (\% BPR) & 64 & 48,6 & 66,7 \\
\hline \multicolumn{4}{|l|}{ Pendidikan $<=$ SLTA } \\
\hline$\%$ rata2 dari komisaris & 114 & 37,3 & 19,2 \\
\hline Jumlah komisaris (\% BPR) & 56 & 45,8 & 50,0 \\
\hline \multicolumn{4}{|l|}{ Pegawai BPR } \\
\hline $\mathrm{Jml}$ rata2 & 114 & 18,3 & 13,0 \\
\hline Jml rata2 direktur & 114 & 1,6 & 2,0 \\
\hline Jml rata2 pegawai tetap. & 114 & 14,6 & 9,0 \\
\hline \multicolumn{4}{|l|}{ Direktur BPR } \\
\hline$\overline{\%}$ BPR dgn 1 org direktur & 49 & 40,3 & 16,7 \\
\hline$\%$ BPR dgn 2 org direktur & 61 & 56,9 & 83,3 \\
\hline$\%$ BPR dgn $>2$ org direktur & 4 & 2,8 & 0,0 \\
\hline \multicolumn{4}{|l|}{ Pengalaman di perbankan } \\
\hline$\%$ rata2 dari direktur & 114 & 50,9 & 55,0 \\
\hline Jumlah direktur (\% BPR) & 49 & 41,7 & 83,0 \\
\hline \multicolumn{4}{|l|}{ Pendidikan $<=$ SLTA } \\
\hline$\%$ rata2 dari direktur & 114 & 28,5 & 0,0 \\
\hline Jumlah direktur (\% BPR) & 18 & 13,9 & 0,0 \\
\hline \multicolumn{4}{|l|}{ Pegawai Tetap } \\
\hline$\%$ BPR dgn 2-9 peg.tetap & 54 & 52,8 & 66,7 \\
\hline$\%$ BPR dgn $10-19$ peg.tetap & 29 & 25,0 & 33,3 \\
\hline$\%$ BPR dgn $>20$ org peg.tetap & 31 & 22,3 & 0,0 \\
\hline \multicolumn{4}{|l|}{ Pengalaman di perbankan } \\
\hline$\%$ rata2 dari peg.tetap & 144 & 13,7 & 16,4 \\
\hline Jlh peg.tetap tdk pengalaman (\% BPR) & 68 & 61,1 & 33,3 \\
\hline \multicolumn{4}{|l|}{ Pendidikan $<=$ SLTA } \\
\hline$\%$ rata2 dari peg.tetap & 144 & 58,6 & 36,4 \\
\hline Seluruh peg.tetap $<=$ SLTA $(\%$ BPR $)$ & 12 & 8,3 & 0 \\
\hline
\end{tabular}

*) Angka prosentase diperoleh dari membandingkan dgn jumlah sampel BPR konv di Jatim dgn kolom sampel BPR konvensional secara secara keseluruhan (Jatim, Bali, dan NTB)

**) Angka prosentase diperoleh dari membadingkan dengan total BPRS di Jatim. 
Tabel III.7a :

Wewenang Manajemen BPR Syariah dan Konvensional Di Jawa Timur

\begin{tabular}{|c|c|c|c|}
\hline & $\begin{array}{l}\text { Jml sampel } \\
\text { BPR Konv. }\end{array}$ & $\begin{array}{c}\text { BPR Konv.* }) \\
\text { di Jatim }\end{array}$ & BPRS $\left.^{* *}\right)$ \\
\hline Jml BPR & 115 & 72 & 6 \\
\hline \multicolumn{4}{|l|}{ Keterlibatan Pemilik (\% BPR) } \\
\hline Keterlibatan dlm operasional & 56 & 52,8 & 0,0 \\
\hline \multicolumn{4}{|l|}{ Wewenang manajemen: } \\
\hline Tinggi & 30 & 29,2 & 50,0 \\
\hline Relatif Tinggi & 24 & 25,0 & 50,0 \\
\hline Relatif Rendah & 46 & 36,1 & 0,0 \\
\hline Rendah & 15 & 9,7 & 0,0 \\
\hline \multicolumn{4}{|l|}{ Manajemen Umum (\% BPR) } \\
\hline Keberadaan rencana tahunan & 114 & 100,0 & 100,0 \\
\hline Keberadaan rencana training & 88 & 70,8 & 100,0 \\
\hline Keberadaan anggaran training & 80 & 65,3 & 100,0 \\
\hline Keberadaan job discription & 111 & 100,0 & 100,0 \\
\hline Keberadaan sistem internal & 77 & 69,5 & 66,7 \\
\hline \multicolumn{4}{|l|}{ Keberadaan manual: } \\
\hline Adm. Dan pembukuan & 107 & 95,8 & 100,0 \\
\hline Analis kredit & 105 & 93,1 & 100,0 \\
\hline Prosedur pesetujuan kredit & 111 & 97,2 & 100,0 \\
\hline Batas pinjaman & 106 & 93,1 & 83,0 \\
\hline Pinjaman ke pihak terkait & 96 & 86,1 & 66,0 \\
\hline Pengawasan pinjaman & 93 & 80,6 & 100,0 \\
\hline \multicolumn{4}{|l|}{ Manajemen keuangan/pinjaman } \\
\hline \multicolumn{4}{|l|}{ Keberadaan kebijakan: } \\
\hline Manajemen likuiditas & 103 & 91,4 & 83,0 \\
\hline BMPK & 100 & 91,7 & 100,0 \\
\hline BMPK ke pihak terkait & 77 & 69,4 & 50,0 \\
\hline PPAP & 108 & 100,0 & 100,0 \\
\hline Penghapusan kredit macet & 62 & 55,6 & 50,0 \\
\hline \multicolumn{4}{|l|}{ Eksekusi agunan: } \\
\hline Tidak Pernah & 81 & 68,1 & 100,0 \\
\hline Pernah lebih dari satu kali & 9 & 6,9 & 0,0 \\
\hline Pernah dgn hasil yg memuaskan & 11 & 33,3 & 0,0 \\
\hline \multicolumn{4}{|l|}{ Lima outstanding kredit terbesar } \\
\hline$<10 \%$ dari portofolio kredit & 68 & 54,3 & 33,0 \\
\hline$>30 \%$ dari portofolio kredit & 11 & 12,9 & 17,0 \\
\hline
\end{tabular}

*) Angka prosentase diperoleh dari membandingkan dgn jumlah sampel BPR konv di Jatim dgn kolom sampel BPR konvensional secara secara keseluruhan

**) Angka prosentase diperoleh dari membandingkan dengan total BPRS di Jatim. 
Tabel III.8a :

Indikator Manajemen terhadap Penggolongan Kinerja Pembiayaan (kredit)

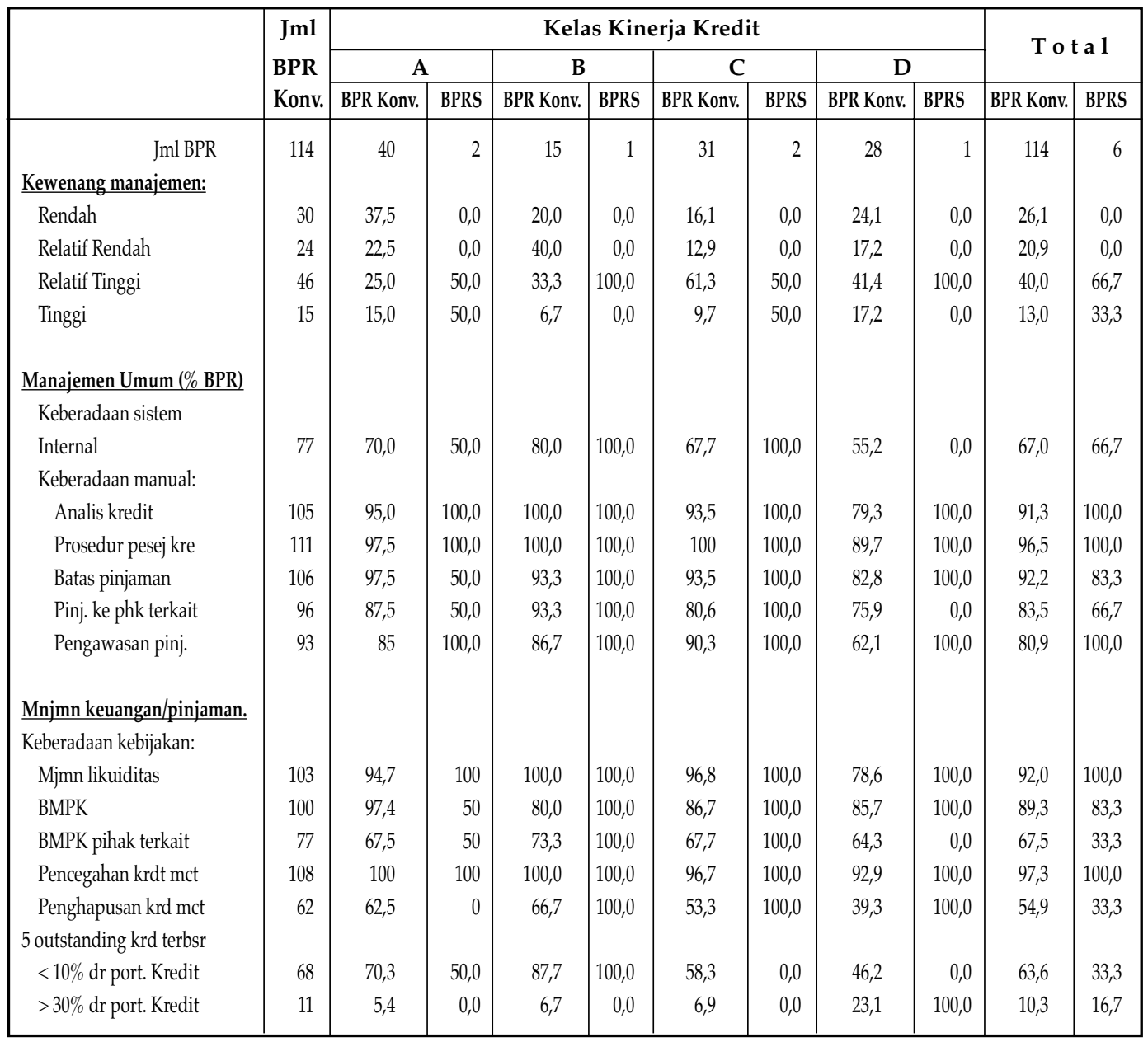

*) Angka prosentase diperoleh dari membandingkan dgn jumlah sampel BPR konv di Jatim,NTB, Bali dgn kolom sampel BPR konvensional secara secara keseluruhan

**) Angka prosentase diperoleh dari membandingkan dengan total BPRS di Jatim.

- Kredit Non lancar: A: <5\%, B: $5-<10 \%$, C: 10-25\%, D: $>25 \%$. 
Tabel III.9a :

Rangking Tujuan pada Rencana kerja Tahunan

\begin{tabular}{|l|r|r|r|r|r|r|}
\hline \multirow{2}{*}{\begin{tabular}{|} 
Faktor \\
R = Rangking N = Jumlah BPR
\end{tabular}} & \multicolumn{2}{c|}{$\begin{array}{c}\text { Total } \\
\text { BPR Konv. }\end{array}$} & \multicolumn{2}{c|}{$\begin{array}{c}\text { BPR Konv. } \\
\text { Jatim }\end{array}$} & \multicolumn{2}{c|}{ BPRS Jatim } \\
\cline { 2 - 8 } & R & $\mathbf{N}=\mathbf{1 0 7}$ & $\mathbf{R}$ & $\mathbf{N}=\mathbf{6 9}$ & $\mathbf{R}$ & $\mathbf{N}=\mathbf{6}$ \\
\hline Menigkatkan penghimpunan dana, asset & 1 & 59 & 1 & 35 & - & - \\
Meningkatkan pemberian pembiayaan/kredit & 2 & 45 & 2 & 25 & - & - \\
Meningkatkan kemampuan SDM & 3 & 32 & 3 & 22 & 2 & 2 \\
Meningkatkan kualitas aktiva produktif & 4 & 29 & 3 & 22 & - & - \\
Meningkatkan pendapatan / BEP & 5 & 17 & 5 & 14 & 3 & 1 \\
Meningkatkan/menjaga tingkat kesehatan bank & 6 & 13 & 6 & 11 & 3 & 1 \\
Mendirikan/mempeluas unit layanan & 7 & 8 & 7 & 5 & 1 & 4 \\
Mengembangkan program komputerisasi kantor & 8 & 7 & 8 & 4 & 2 & 2 \\
Meneriman pegawai baru & 9 & 5 & - & 3 & - & - \\
Meningkatkan motivasi / disiplin pegawai & 10 & 5 & - & 3 & - & - \\
Meningkatkan manajemen/internal kontrol & - & - & 8 & 4 & - & - \\
Meningkat modal disetor & - & - & 8 & 4 & 3 & 1 \\
\hline
\end{tabular}

Tabel III.10a :

Ranking terhadap Manajemen Likuiditas

\begin{tabular}{|l|r|r|r|r|r|r|}
\hline \multirow{2}{*}{$\begin{array}{c}\text { Faktor } \\
\text { R = Rangking N = Jumlah BPR }\end{array}$} & \multicolumn{2}{|c|}{$\begin{array}{c}\text { Total } \\
\text { BPR Konv. }\end{array}$} & \multicolumn{2}{c|}{$\begin{array}{c}\text { BPR Konv. } \\
\text { Jatim }\end{array}$} & \multicolumn{2}{c|}{ BPRS Jatim } \\
\cline { 2 - 7 } & $\mathbf{R}$ & $\mathbf{N}=\mathbf{9 9}$ & $\mathbf{R}$ & $\mathbf{N}=\mathbf{6 9}$ & $\mathbf{R}$ & $\mathbf{N}=\mathbf{6}$ \\
\hline Uang tunai / Simpanan pada bank lain .. \% dari DPK & 1 & 28 & 2 & 11 & 1 & 5 \\
Berdasarkan aliran kas sesuai dgn jangka waktunya & 2 & 19 & 1 & 15 & 2 & 2 \\
Likuiditas seperti pada CAMEL & 3 & 15 & 3 & 10 & 2 & 2 \\
BMPK kpd pihak terkait, meningkatkan kolektibilitas, & & & & & & \\
mobilisasi tabungan. & 4 & 12 & 4 & 5 & & - \\
Program penjaminan simpanan & 5 & 5 & 4 & 5 & & - \\
Ketersedian modal tambahan, pinjaman dr phk terkait & 6 & 4 & 6 & 4 & & - \\
Lainnya dgn jawan tdk terinci & & 16 & & 11 & & - \\
\hline
\end{tabular}


Tabel III.11a :

Pengalaman BPR: Faktor yang menyebabkan kegagalan kredit

\begin{tabular}{|c|c|c|c|c|c|c|}
\hline \multirow{2}{*}{$\begin{array}{c}\text { Faktor } \\
\mathrm{R}=\text { Rangking } \mathbf{N}=\text { Jumlah } \mathrm{BPR}\end{array}$} & \multicolumn{2}{|c|}{$\begin{array}{c}\text { Total } \\
\text { BPR Konv. }\end{array}$} & \multicolumn{2}{|c|}{$\begin{array}{l}\text { BPR Konv. } \\
\text { Jatim }\end{array}$} & \multicolumn{2}{|c|}{ BPRS Jatim } \\
\hline & $\mathbf{R}$ & $\mathbf{N}=108$ & $\mathbf{R}$ & $N=69$ & $\mathbf{R}$ & $\mathbf{N}=6$ \\
\hline FAKTOR YG BERHUB. DGN KARAKTER & 1 & 87 & 1 & 48 & 2 & 2 \\
\hline Umum & & 37 & & 24 & & 2 \\
\hline Alamat berubah tanpa pemberitahuan & & 21 & & 7 & & - \\
\hline Kredit digunakan berbeda dgn kontrak & & 15 & & 8 & & - \\
\hline Kredit digunakan oleh pihak lain & & 7 & & 5 & & - \\
\hline Jaminan dijual oleh debitur & & 7 & & 4 & & - \\
\hline KONDISI EKONOMI \& KEGAGALAN BISNIS & 2 & 72 & 2 & 44 & 1 & 3 \\
\hline FAKTOR INTERNAL BANK & 3 & 55 & 3 & 38 & - & - \\
\hline Analisis dan prosedur kredit yg tdk memadai & & 30 & & 20 & & - \\
\hline Tdk ada atau kurangnya jaminan tetap & & 10 & & 6 & & - \\
\hline Kolusi dan campur tangan pihak luar & & 8 & & 7 & & - \\
\hline Tindakan terlambat, monitoring dan kurang bimbingan & & 7 & & 5 & & \\
\hline FAKTOR EKSTERNAL LAINNYA & 4 & 42 & 4 & 23 & 3 & 1 \\
\hline Bencana alam atau pada manusia & & 34 & & 19 & & - \\
\hline Jaminan dijual hilang atau rusak & & 8 & & 4 & & - \\
\hline Tidak memakai jaminan & & - & & - & & 1 \\
\hline
\end{tabular}

Tabel III.12a

Rangking Strategi untuk Menghindari Kredit Macet

\begin{tabular}{|c|c|c|c|c|c|c|}
\hline \multirow{2}{*}{$\begin{array}{c}\text { Strategi } \\
\mathrm{R}=\text { Rangking } \mathbf{N}=\text { Jumlah } \mathrm{BPR}\end{array}$} & \multicolumn{2}{|c|}{ Total } & \multicolumn{2}{|c|}{ Jatim } & \multicolumn{2}{|c|}{ BPRS } \\
\hline & $\mathbf{R}$ & $\mathbf{N}=110$ & $\mathbf{R}$ & $\mathrm{N}=72$ & $\mathbf{R}$ & $\mathbf{N}=6$ \\
\hline Monitoring kontinu, hubungan dan bimbingan secara pribadi & 1 & 41 & 1 & 31 & 2 & 3 \\
\hline Informasi yg cukup dan analisa kredit yang Memadai (5C) & 2 & 37 & 2 & 26 & 1 & 6 \\
\hline Jaminan yg cukup, dan jaminan yang mudah dijual & 3 & 28 & 3 & 16 & 3 & 2 \\
\hline Berhati-hati dlm memilihan peminjan dan persetujuan kredit yg selektif & 4 & 27 & 3 & 16 & 4 & 1 \\
\hline Meningkatkan kemampuan petugas kredit dan meningkatkan prosedur kredit & 5 & 11 & 5 & 8 & - & - \\
\hline Penagihan kredit yg intensip dan membentu tim penyelamat kredit & 6 & 11 & 6 & 7 & 4 & 1 \\
\hline $\begin{array}{l}\text { Membuat komite kredit dan menyakinkan akan adanya keputusan kredit yg } \\
\text { transparan }\end{array}$ & 7 & 5 & 7 & 3 & - & - \\
\hline $\begin{array}{l}\text { Pembentukan cadangan penghapusan kredit macet yg cukup dan penghapus- } \\
\text { bukuannya }\end{array}$ & 8 & 5 & 7 & 3 & - & - \\
\hline Rescheduling, restructuring dan reconditioning thd kredit bermasalah & 9 & 4 & 9 & 1 & - & - \\
\hline Lainnya atau jawaban tidak dirinci & - & 7 & - & 4 & 4 & 1 \\
\hline
\end{tabular}

Tabel III.13a :

Rangking tindakan yang diambil jika terjadi kemacetan

\begin{tabular}{|l|r|r|r|r|r|r|}
\hline \multicolumn{1}{|c|}{ Tinndakan } & \multicolumn{2}{|c|}{ Total } & \multicolumn{2}{c|}{ Jatim } & \multicolumn{2}{c|}{ BPRS } \\
\cline { 2 - 7 } R = Rangking N = Jumlah BPR & $\mathbf{R}$ & $\mathbf{N}=\mathbf{1 0 7}$ & $\mathbf{R}$ & $\mathbf{N}=\mathbf{7 0}$ & $\mathbf{R}$ & $\mathbf{N}=\mathbf{2 2}$ \\
\hline Kunjungan berkala, upaya penagihan dan Bimbingan & 1 & 35 & 2 & 25 & 1 & 6 \\
Menerapkan pinalti & 1 & 35 & 1 & 28 & 3 & 1 \\
Mengirimkan surat peringatan formal & 3 & 17 & 3 & 11 & 1 & 6 \\
Rescheduling, restructuring dan reconditioning thd kredit & 3 & 17 & 4 & 9 & 2 & 5 \\
Mengurangi pinalti dan bunga pinjaman & 5 & 16 & 5 & 8 & - & - \\
Mengikat jaminan & 6 & 5 & 6 & 4 & - & - \\
Lainnya atau tidak merinci jawaban & - & 12 & - & 8 & - & - \\
\hline
\end{tabular}


Tabel III.14a :

Ranking pinjaman kepada pihak terkait

\begin{tabular}{|l|r|r|r|r|r|r|}
\hline \multicolumn{1}{|c|}{ Kebijaksanaan } & \multicolumn{2}{|c|}{ Total } & \multicolumn{2}{|c|}{ Jatim } & \multicolumn{2}{c|}{ BPRS } \\
\cline { 2 - 7 } R = Rangking N = Jumlah BPR & R & $\mathbf{N}=\mathbf{7 9}$ & $\mathbf{R}$ & $\mathbf{N}=\mathbf{5 3}$ & $\mathbf{R}$ & $\mathbf{N}=\mathbf{6}$ \\
\hline Menerapkan peraturan BI & $\mathbf{1}$ & 49 & $\mathbf{1}$ & 42 & $\mathbf{1}$ & $\mathbf{6}$ \\
Menyediakan bunga rendah, jangka waktu & & & & & & \\
dan persyaratan yg lebih baik & $\mathbf{2}$ & 15 & $\mathbf{3}$ & 2 & $\mathbf{3}$ & 1 \\
Menerapkan peraturan kredit umumnya, & $\mathbf{3}$ & 11 & $\mathbf{2}$ & 4 & $\mathbf{2}$ & 2 \\
sesuai dengan kemampuan membayar & & & & & & \\
Menerapkan aturan jaminan yang baku & $\mathbf{4}$ & 5 & $\mathbf{2}$ & 4 & - & - \\
Hanya melayani keb yg sangat mendesak & - & - & - & - & $\mathbf{3}$ & 1 \\
Tidak menyediakan kredit pd pihak terkait & $\mathbf{5}$ & 5 & $\mathbf{2}$ & 4 & - & - \\
Menerapkan jumlah maks. Pinjaman Individual & $\mathbf{6}$ & 4 & $\mathbf{3}$ & 2 & - & - \\
\hline
\end{tabular}

Tabel III.15a :

Ranking kebijakan BMPK

\begin{tabular}{|c|c|c|c|c|c|c|}
\hline \multirow{2}{*}{$\begin{array}{c}\text { Kebijakan } \\
\mathrm{R}=\text { Rangking } \mathrm{N}=\text { Jumlah BPR }\end{array}$} & \multicolumn{2}{|c|}{ Total } & \multicolumn{2}{|c|}{ Jatim } & \multicolumn{2}{|c|}{ BPRS } \\
\hline & $\mathbf{R}$ & $\mathrm{N}=91$ & $\mathbf{R}$ & $\mathrm{N}=67$ & $\mathbf{R}$ & $N=6$ \\
\hline Menerapkan peraturan BI & 1 & 67 & 1 & 45 & 1 & 6 \\
\hline $\begin{array}{l}\text { Mengetatkan kewenangan manajemen dalam } \\
\text { menyetujui pemeberian kredit }\end{array}$ & 2 & 13 & 2 & 7 & - & - \\
\hline $\begin{array}{l}\text { Diberikan kewenangan yg jelas oleh komisaris } \\
\text { dan direktur }\end{array}$ & 3 & 6 & 3 & 4 & - & - \\
\hline $\begin{array}{l}\text { Menerapkan yang lebih ketat dibandingkan dgn } \\
\text { peraturan BI }\end{array}$ & 4 & 3 & 4 & 3 & - & - \\
\hline Membatasi pemberian kredit sesuai dgn & & & & & & \\
\hline Keb. peminjam (analisis kredit yg benar) & 5 & 3 & 5 & 2 & - & - \\
\hline Menerapkan maks. kredit bagi debitur indidual & 6 & 3 & 6 & 1 & - & - \\
\hline Lainnya atau tidak merinci jawaban & - & 8 & - & 6 & - & - \\
\hline
\end{tabular}


Tabel III.16a :

Ranking aturan penghapus-bukuan kredit macet

\begin{tabular}{|c|c|c|c|c|c|c|}
\hline \multirow{2}{*}{$\begin{array}{c}\text { A } t \text { u } r \text { a } n \\
R=\text { Rangking } N=\text { Jumlah } B P R\end{array}$} & \multicolumn{2}{|c|}{ Total } & \multicolumn{2}{|c|}{ Jatim } & \multicolumn{2}{|c|}{ BPRS } \\
\hline & $\mathbf{R}$ & $N=65$ & $\mathbf{R}$ & $N=42$ & $\mathbf{R}$ & $\mathbf{N}=6$ \\
\hline Menerapkan aturan yg sdh ada & 1 & 13 & 1 & 9 & 1 & 6 \\
\hline $\begin{array}{l}\text { Menghapusbukan sisa kredit jika jaminan } \\
\text { tidak cukup atau tdk mudah dipasarkan }\end{array}$ & 2 & 11 & 1 & 9 & & \\
\hline $\begin{array}{l}\text { Pengapusbukuan harus disetujui oleh } \\
\text { pemilik dan dewan komisaris }\end{array}$ & 3 & 11 & 3 & 6 & 3 & 1 \\
\hline $\begin{array}{l}\text { Penghapusbukuan berdasarkan pada } \\
\text { kapasitas PPAP }\end{array}$ & 4 & 9 & 3 & 6 & - & - \\
\hline $\begin{array}{l}\text { Penghapusbukuan setelah kredit ( .. bln) } \\
\text { diklasifikasi macet }\end{array}$ & 5 & 8 & 5 & 4 & 2 & 3 \\
\hline Menagih tunggakan setelah kredit di- & & & & & & \\
\hline Hapusbukuan & 6 & 4 & 6 & 3 & - & - \\
\hline $\begin{array}{l}\text { Menyediakan cadangan kredit macet } \\
\text { dalam jumlah yang cukup }\end{array}$ & 7 & 3 & 7 & 1 & 3 & 1 \\
\hline $\begin{array}{l}\text { Menghapusbukan kredit macet pada } \\
\text { akhir tahun buku }\end{array}$ & 8 & 2 & 7 & 1 & - & - \\
\hline Lainnya tidak merinci jawaban & - & 4 & - & 3 & - & - \\
\hline
\end{tabular}

Tabel III.17a :

Pengalaman dan pendapat tentang mengesekusi jaminan

\begin{tabular}{|c|c|c|c|c|c|c|}
\hline \multirow{2}{*}{$\begin{array}{l}\text { BPR dgn Pengalaman Eksekusi } \\
\mathrm{R}=\text { Rangking } \mathrm{N}=\text { Jumlah BPR }\end{array}$} & \multicolumn{2}{|c|}{ Total } & \multicolumn{2}{|c|}{ Jatim } & \multicolumn{2}{|c|}{ BPRS } \\
\hline & $\mathbf{R}$ & $\mathbf{N}=32$ & $\mathbf{R}$ & $\mathbf{N}=\mathbf{2 3}$ & $\mathbf{R}$ & $\mathbf{N}=0$ \\
\hline $\begin{array}{l}\text { Tidak puas: Randahnya tranfaransi, } \\
\text { terlalu mahal, dan prosedurnya panjang }\end{array}$ & 1 & 20 & 1 & 15 & - & - \\
\hline $\begin{array}{l}\text { Puas: Kerjasama yg baik dgn pengadilan } \\
\text { dan lembaga pelelangan }\end{array}$ & 2 & 5 & 4 & 1 & - & - \\
\hline Tidak puas:Alasan lainnya & 3 & 4 & 2 & 4 & - & - \\
\hline Masih dalam proses & 4 & 3 & 3 & 3 & - & - \\
\hline BPR tanpa Pengalaman Eksekusi & $\mathbf{R}$ & $\mathbf{N}=73$ & $\mathbf{R}$ & $N=42$ & $\mathbf{R}$ & $\mathbf{N}=\mathbf{5}$ \\
\hline $\begin{array}{l}\text { Tdk Effisien: Telalu mahal u / kredit kecil } \\
\text { Terlalu berbelit-belit dan lama }\end{array}$ & 1 & 39 & 1 & 26 & 1 & 2 \\
\hline $\begin{array}{l}\text { Lebih menyukai eksekusi informal bekerja } \\
\text { sama dgn debitur }\end{array}$ & 2 & 17 & 2 & 9 & 1 & 2 \\
\hline Tidak ada kredit macet, belum dibutuhkan & 3 & 12 & 3 & 7 & - & - \\
\hline Tidak pengalaman, tdk mengerti prosedurnya & 4 & 4 & - & - & - & - \\
\hline Memperburuk citra BPR, dikritik krn terlalu kejam & 5 & 1 & - & - & 2 & 1 \\
\hline
\end{tabular}


Tabel III.18a :

Masalah Utama yang diungkapkan oleh Direktur BPR

\begin{tabular}{|c|c|c|c|c|c|c|}
\hline \multirow{2}{*}{$\begin{array}{c}\text { Masalah } \\
\mathrm{R}=\text { Rangking } \mathbf{N}=\text { Jumlah BPR }\end{array}$} & \multicolumn{2}{|c|}{ Total } & \multicolumn{2}{|c|}{ Jatim } & \multicolumn{2}{|c|}{ BPRS } \\
\hline & $\mathbf{R}$ & $\mathbf{N}=99$ & $\mathbf{R}$ & $\mathbf{N}=70$ & $\mathbf{R}$ & $\mathbf{N}=\mathbf{5}$ \\
\hline \multicolumn{7}{|l|}{ OPERATIONAL } \\
\hline Penagihan dan kredit macet & 1 & 61 & 1 & 44 & 1 & 4 \\
\hline Rendahnya mobilisasi dana dan modal & 3 & 22 & 3 & 14 & 2 & 3 \\
\hline Persaingan & 5 & 18 & 6 & 10 & 1 & 4 \\
\hline Ekspansi kredit, over likuid & 8 & 9 & 7 & 8 & - & - \\
\hline Pengambilan dan eksekusi jaminan & 9 & 8 & 8 & 6 & - & - \\
\hline Citra BPR buruk dan rendahnya kepercayaan & 11 & 6 & 9 & 5 & - & - \\
\hline Kurang Promosi & - & - & - & - & 3 & 2 \\
\hline Pemilik terlalu banyak sulit menambah modal & - & - & - & - & 3 & 2 \\
\hline \multicolumn{7}{|l|}{ SDM } \\
\hline Rendahnya kemampuan pegawai & 2 & 33 & 2 & 19 & 2 & 3 \\
\hline Rendahnya kualitas pegawai baru & 4 & 20 & 3 & 14 & - & - \\
\hline Rendahnya disiplin dan motivasi pegawai & 6 & 15 & 5 & 11 & - & - \\
\hline \multicolumn{7}{|l|}{ ORGANISASI } \\
\hline Rendahnya struktur organisasi \& pembagian peg. & 7 & 11 & 12 & 3 & 4 & 1 \\
\hline Sedikitnya ruang dan fasilitas kantor & 9 & 8 & 10 & 4 & 2 & 3 \\
\hline Akunting yg lemah dan mslh pajak akuntansi & 11 & 6 & 10 & 4 & - & - \\
\hline Rendahnya wewenang dan campur tangan phk luar & 13 & 4 & 12 & 3 & - & - \\
\hline Tidak effektifnya dewan komisaris & 13 & 4 & 14 & 2 & 4 & 1 \\
\hline
\end{tabular}

Tabel III.19a :

Kebutuhan Training bagi Direktur BPR

\begin{tabular}{|l|r|r|r|r|r|r|}
\hline \multicolumn{1}{|c|}{ Masalah } & \multicolumn{2}{|c|}{ Total } & \multicolumn{2}{c|}{ Jatim } & \multicolumn{2}{c|}{ BPRS } \\
\cline { 2 - 6 } R = Rangking N = Jumlah BPR & $\mathbf{R}$ & $\mathbf{N}=\mathbf{1 0 6}$ & $\mathbf{R}$ & $\mathbf{N}=\mathbf{6 7}$ & $\mathbf{R}$ & $\mathbf{N}=\mathbf{6}$ \\
\hline Tidak membutuhkan Training & - & 22 & - & 14 & - & - \\
Manajemen BPR, Internal Kontrol & $\mathbf{1}$ & 35 & $\mathbf{1}$ & 21 & - & 1 \\
Manajemen Umum (Syariah), Leadership, Perencanaan & & & & & & \\
Strategis \& pengambilan keputusan. & $\mathbf{2}$ & 27 & $\mathbf{2}$ & 14 & $\mathbf{1}$ & 6 \\
Manajemen Risiko dan keuangan & $\mathbf{3}$ & 12 & $\mathbf{5}$ & 5 & $\mathbf{2}$ & 3 \\
Manajemen Sumber Daya Manusia & $\mathbf{4}$ & 11 & $\mathbf{3}$ & 8 & $\mathbf{3}$ & 2 \\
Aspek hukum dan perpajakan & $\mathbf{4}$ & 11 & $\mathbf{3}$ & 8 & $\mathbf{4}$ & 1 \\
Pemasaran & $\mathbf{6}$ & 4 & $\mathbf{6}$ & 3 & $\mathbf{4}$ & 1 \\
Akuntansi & $\mathbf{6}$ & 4 & $\mathbf{6}$ & 3 & $\mathbf{4}$ & 1 \\
Lainnya: Pendidikan Formal, Ekonomi makro dan moneter & - & 6 & - & 2 & - & - \\
\hline
\end{tabular}

Tabel III.20a :

Kebutuhan Training bagi Staf Pembiayaan BPR

\begin{tabular}{|l|r|r|r|r|r|r|}
\hline \multicolumn{1}{|c|}{ Masalah } & \multicolumn{2}{|c|}{ Total } & \multicolumn{2}{c|}{ Jatim } & \multicolumn{2}{c|}{ BPRS } \\
\cline { 2 - 7 } R = Rangking N = Jumlah BPR & $\mathbf{R}$ & $\mathbf{N}=\mathbf{1 0 6}$ & $\mathbf{R}$ & $\mathbf{N}=\mathbf{6 7}$ & $\mathbf{R}$ & $\mathbf{N}=\mathbf{6}$ \\
\hline Tidak membutuhkan Training & - & 7 & - & 5 & - & - \\
Kredit secara umum \& administrasi Training AO & $\mathbf{1}$ & 35 & $\mathbf{1}$ & 20 & $\mathbf{1}$ & 4 \\
Analisis Kredit, resiko dan usaha & $\mathbf{2}$ & 27 & $\mathbf{2}$ & 16 & $\mathbf{2}$ & 3 \\
Markerting dan custumer relations & $\mathbf{3}$ & 12 & $\mathbf{3}$ & 14 & - & - \\
Penagihan kredit dan penyelamatan kredit & $\mathbf{4}$ & 11 & $\mathbf{3}$ & 14 & $\mathbf{3}$ & 2 \\
Pengawasan dan monitoring kredit & $\mathbf{4}$ & 11 & $\mathbf{5}$ & 11 & $\mathbf{3}$ & 2 \\
Aplikasi komputer & $\mathbf{6}$ & 4 & - & - & $\mathbf{2}$ & 3 \\
Lainnya: Aspek manajemen BPR & $\mathbf{6}$ & 4 & - & 3 & - & - \\
\hline
\end{tabular}


Tabel III.21a :

Kebutuhan Training bagi Staf BPR Lainnya

\begin{tabular}{|l|r|r|r|r|r|r|}
\hline \multicolumn{1}{|c|}{ Masalah } & \multicolumn{2}{c|}{ Total } & \multicolumn{2}{c|}{ Jatim } & \multicolumn{2}{c|}{ BPRS } \\
\cline { 2 - 7 } \multicolumn{1}{|c|}{$\mathbf{R}$ = Rangking N = Jumlah BPR } & $\mathbf{R}$ & $\mathbf{N}=\mathbf{1 0 6}$ & $\mathbf{R}$ & $\mathbf{N}=\mathbf{6 7}$ & $\mathbf{R}$ & $\mathbf{N}=\mathbf{6}$ \\
\hline Tidak membutuhkan Training & - & 7 & - & 13 & - & - \\
Analisis keuangan dan manajemen & $\mathbf{1}$ & 33 & $\mathbf{1}$ & 22 & $\mathbf{4}$ & 1 \\
Akuntansi & $\mathbf{2}$ & 28 & $\mathbf{2}$ & 21 & $\mathbf{4}$ & 1 \\
Perangkat keras dan lunak & $\mathbf{3}$ & 23 & $\mathbf{4}$ & 12 & - & - \\
Pelaporan umum dan keuangan & $\mathbf{4}$ & 21 & $\mathbf{5}$ & 10 & $\mathbf{3}$ & 2 \\
Hubungan dengan nasabah dan pemasaran & $\mathbf{5}$ & 20 & $\mathbf{3}$ & 15 & $\mathbf{3}$ & 2 \\
Aspek hukum dan perpajakan & $\mathbf{6}$ & 11 & $\mathbf{6}$ & 9 & $\mathbf{3}$ & 2 \\
Penanganan uang palsu & $\mathbf{7}$ & 5 & $\mathbf{7}$ & 4 & - & - \\
Magang di BPR lainnya & & & & & $\mathbf{2}$ & $\mathbf{3}$ \\
Manajemen Oprs. & & & & & 1 & 6 \\
Lainnya & - & 6 & - & 6 & - & - \\
\hline
\end{tabular}

Tabel IV.1a :

Aspek Pelayanan BPR Konvensional dan Syariah

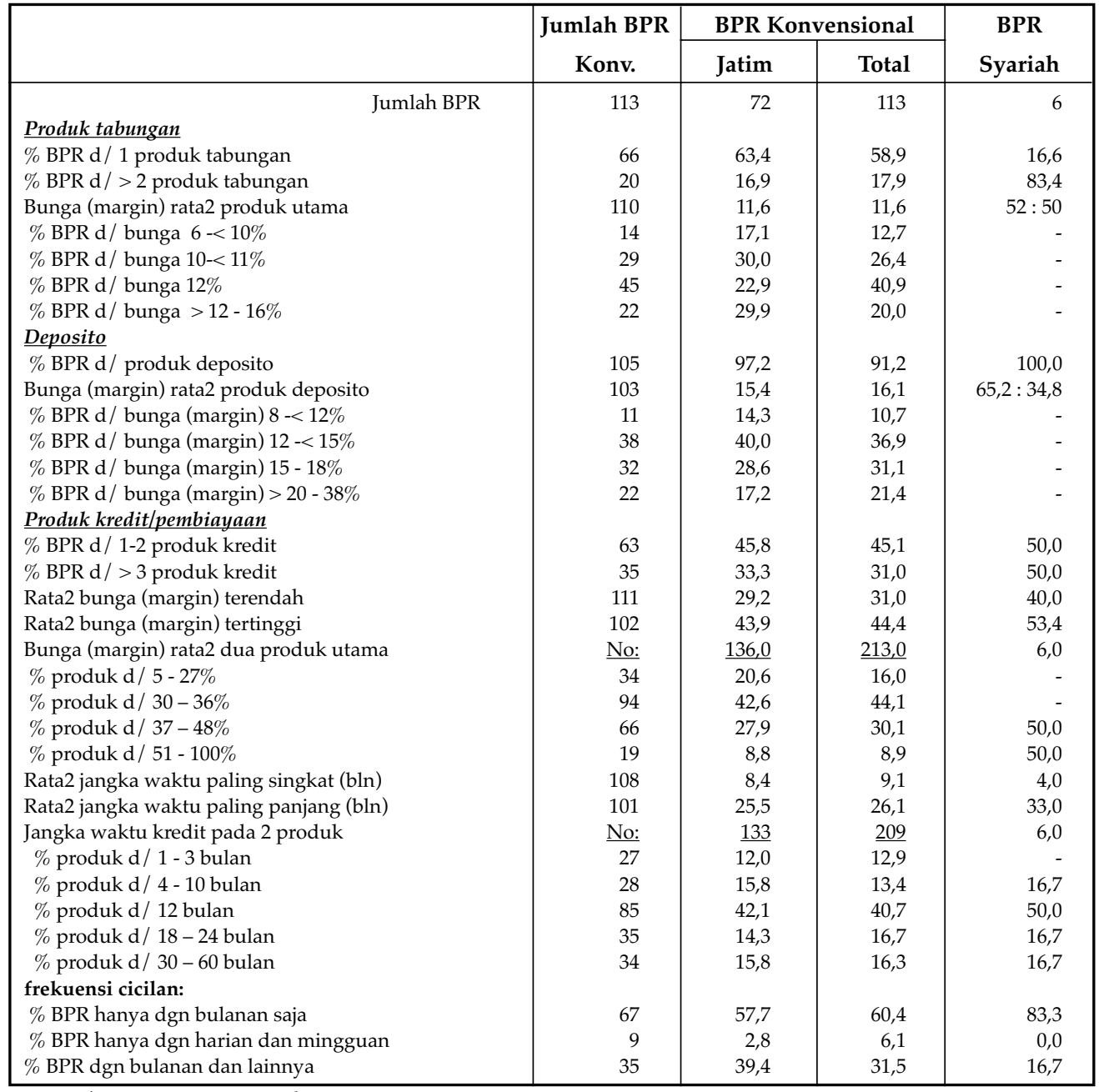

Ket: d/ = dgn; margin = bagi hasil pada BPRS; 
Tabel IV.2a :

Jangkauan geografis dan persaingan BPR Konvensional dan Syariah

\begin{tabular}{|c|c|c|c|c|}
\hline & \multicolumn{2}{|c|}{ BPR Konvensional } & \multirow{2}{*}{$\begin{array}{c}\text { BPR } \\
\text { Syariah }\end{array}$} \\
\hline & & Jatim & Total & \\
\hline \multicolumn{2}{|c|}{ Jumlah BPR } & 72 & 114 & 6 \\
\hline \multicolumn{5}{|l|}{ Lokasi } \\
\hline Jarak Rata2 (Km) ke Ibukota Kab / Kodya & 112 & 16,1 & 17,2 & 16,0 \\
\hline \% BPR dalam Ibukota Kab/Kodya & 18 & 16,1 & 7,7 & 0,0 \\
\hline$\%$ BPR > 25 km ke Ibukota Kab/Kodya & 24 & 22,2 & 21,4 & 16,7 \\
\hline Jarak Rata2 (Km) ke Kecamatan & 113 & 1,3 & 1,5 & 0,8 \\
\hline$\%$ BPR di Kecamatan & 76 & 66,7 & 67,3 & 100,0 \\
\hline$\%$ BPR > 5 km ke kecamatan & 7 & 5,6 & 6,2 & 0,0 \\
\hline$\%$ BPR di prs.tradisonal/pusat perdag. & 79 & 73,6 & 69,9 & 66,7 \\
\hline$\%$ BPR pada jln utama & 107 & 97,2 & 94,7 & 100,0 \\
\hline$\%$ BPR di daerah turis & 18 & 9,7 & 15,9 & 0,0 \\
\hline \multicolumn{5}{|l|}{ Jangkauan geografis } \\
\hline$\% \mathrm{BPR} \mathrm{d} /$ lebih dari 1 kantor & 15 & 13,2 & 13,2 & 50,0 \\
\hline Jumlah rata2 kecamatan yang dilayani & 114 & 12,2 & 9,2 & 12,4 \\
\hline$\%$ BPR melayani 1 - 4 kecamatan & 40 & 15,3 & 35,1 & 0,0 \\
\hline$\%$ BPR melayani $=>10$ kecamatan & 36 & 48,6 & 31,6 & 67,7 \\
\hline \multicolumn{5}{|l|}{ Tabungan pd. kantor pusat BPR di kec.pusat } \\
\hline$\%$ Rata2 jumlah tabungan & 111 & 49,7 & 57,4 & 30,0 \\
\hline$\% \mathrm{BPR} d / 100 \%$ terkonsentrasi & 13 & 2,9 & 11,7 & 0,0 \\
\hline$\%$ BPR d / < 50\% terkonsentrasi & 54 & 60,0 & 48,6 & 44,2 \\
\hline \multicolumn{5}{|l|}{ Kredit pd. kantor pusat BPR di kec. pusat } \\
\hline \% Rata2 portofolio kredit/pembiayaan & 112 & 40,6 & 50,5 & 46,8 \\
\hline$\%$ BPR d/ 100\% terkonsentrasi & 8 & - & 7,1 & 0,0 \\
\hline$\% \mathrm{BPR} d /<50 \%$ terkonsentrasi & 24 & 29,6 & 21,4 & 33,4 \\
\hline \multicolumn{5}{|l|}{ Situasi persaingan } \\
\hline$\%$ BPR: yg merasa tdk mempunyai saingan & 17 & 16,7 & 14,8 & 0,0 \\
\hline$\%$ BPR: $>2$ pesaing & 55 & 43,0 & 47,8 & 100,0 \\
\hline Lembaga pesaing yg disebutkan: & & & & \\
\hline \% BPR: Bank komersial & 70 & 56,9 & 64,3 & 33,4 \\
\hline \% BPR: BRI unit & 50 & 50,0 & 43,5 & 83,4 \\
\hline \% BPR: BPR lainnya & 43 & 36,1 & 37,4 & 83,4 \\
\hline$\%$ BPR: LDKP & 18 & 4,2 & 15,7 & 0,0 \\
\hline \% BPR: Koperasi dan lembaga keu. Lainnya & 43 & 30,6 & 37,4 & 83,4 \\
\hline
\end{tabular}


Tabel IV.3a :

Konsumen dijangkau BPR Konvensional dan Syariah

\begin{tabular}{|c|c|c|c|c|}
\hline & \multirow{2}{*}{\begin{tabular}{|c|} 
Jumlah BPR \\
Konv. \\
\end{tabular}} & \multicolumn{2}{|c|}{ BPR Konvensional } & \multirow{2}{*}{$\begin{array}{c}\text { BPR } \\
\text { Syariah }\end{array}$} \\
\hline & & Jatim & Total & \\
\hline & & 72 & 115 & 6 \\
\hline \multicolumn{5}{|l|}{ Portofolio kredit/pembiayaan } \\
\hline Rata-rata jumlah rekening & 113 & 816,0 & 887,0 & 512,0 \\
\hline Rata2 $\%$ rekening $<$ Rp. 1 juta & 109 & 49,1 & 51,3 & 64,0 \\
\hline Rata2 \% rekening > Rp. 5 juta & 109 & 13,7 & 13,0 & 6,4 \\
\hline Rata2 nilai per rekening (Rp.juta) & 113 & 3,4 & 2,9 & 1,8 \\
\hline Rata2 \% nilai < Rp. 1 juta & 111 & 19,6 & 22,9 & 21,0 \\
\hline Rata2 \% nilai > Rp. 5 juta & 111 & 34,0 & 8,5 & 43,2 \\
\hline \multicolumn{5}{|l|}{ Tabungan } \\
\hline Rata-rata rekening & 111 & $2.235,0$ & $3.383,0$ & $1.434,0$ \\
\hline Rata2 \% rekening < Rp. 0.5 juta & 111 & 86,2 & 83,7 & 89,2 \\
\hline Rata2 \% rekening > Rp. 1 juta & 111 & 4,4 & 6,7 & 8,5 \\
\hline Rata2 jlh nilai (Rp. 000) & 111 & 512,0 & 437,0 & 354,0 \\
\hline Rata2 \% nilai < Rp. 0.5 juta & 111 & 26,1 & 30,2 & 21,0 \\
\hline Rata2 \% nilai > Rp. 1 juta & 111 & 63,3 & 57,6 & 71,0 \\
\hline \multicolumn{5}{|l|}{ Deposito } \\
\hline Rata-rata rekening & 107 & 99,0 & 107,0 & 26,0 \\
\hline Rata2 \% rekening < Rp. 1 juta & 107 & 16,6 & 20,1 & 21,5 \\
\hline Rata2 \% rekening $>$ Rp. 5 juta & 107 & 44,8 & 38,4 & 44,3 \\
\hline Rata2 jlh nilai (Rp.juta) & 107 & 25,1 & 18,3 & 9,7 \\
\hline Rata2 \% nilai < Rp. 1 juta & 107 & 5,5 & 8,2 & 1,7 \\
\hline Rata2 \% nilai $>$ Rp. 5 juta & 107 & 74,2 & 66,6 & 91,0 \\
\hline \multicolumn{5}{|l|}{ Pinj. Berdsrkan tujuan/Sektor) } \\
\hline \multicolumn{5}{|l|}{ KMK/Investasi } \\
\hline Rata2 \% rekening & 115 & 79,5 & 75,7 & 88,4 \\
\hline Rata2 \% nilai & 115 & 81,2 & 77,7 & 96,7 \\
\hline \multicolumn{5}{|l|}{ Konsumsi } \\
\hline Rata2 \% rekening & 112 & 14,9 & 19,1 & 4,9 \\
\hline Rata2 \% nilai & 112 & 11,8 & 16,7 & 2,1 \\
\hline \multicolumn{5}{|l|}{ Perdagangan } \\
\hline Rata2 \% rekening & 111 & 49,3 & 52,4 & 80,3 \\
\hline Rata2 \% nilai & 111 & 48,7 & 51,8 & 76,6 \\
\hline \multicolumn{5}{|l|}{ Pertanian } \\
\hline Rata2 \% rekening & 111 & 16,8 & 13,9 & 9,7 \\
\hline Rata2 \% nilai & 111 & 17,6 & 13,4 & 11,5 \\
\hline \multicolumn{5}{|l|}{ Jasa } \\
\hline Rata2 \% rekening & 111 & 8,5 & 8,3 & 5,9 \\
\hline Rata2 \% nilai & 111 & 11,5 & 11,7 & 8,2 \\
\hline
\end{tabular}


Tabel IV.4a :

(Pelayanan dan jangkauan berdasarkan kelas asset)

\begin{tabular}{|c|c|c|c|c|c|c|c|c|c|c|c|}
\hline & \multirow{3}{*}{$\begin{array}{r}\text { Jml } \\
\text { BPR }\end{array}$} & \multicolumn{8}{|c|}{ Kelas Asset } & \multirow{2}{*}{\multicolumn{2}{|c|}{ Total }} \\
\hline & & \multicolumn{2}{|c|}{$\mathbf{A}$} & \multicolumn{2}{|c|}{ B } & \multicolumn{2}{|l|}{$\mathrm{C}$} & \multicolumn{2}{|c|}{ D } & & \\
\hline & & BPR Konv. & BPRS & BPR Konv. & BPRS & BPR Konv. & BPRS & BPR Konv. & BPRS & BPR Konv. & BPRS \\
\hline Jml BPR & & 29 & 3 & 29 & & 35 & 3 & 21 & & 114 & 6 \\
\hline Jasa-jasa & & & & & & & & & & & \\
\hline Bunga tabungan $<12 \%$ & 43 & 22,2 & & 41,4 & & 51,5 & & 46,9 & & 39,1 & \\
\hline Bunga tabungan $>12 \%$ & 22 & 29,6 & & 20,6 & & 17,2 & & 10,6 & & 20,0 & \\
\hline Nisbah Tabungan (BPRS) & 6 & & $50: 50$ & & - & & $50: 50$ & & - & & $50: 50$ \\
\hline Bunga Deposito < 15\% & 49 & 22,7 & & 46,2 & & 54,2 & & 65,0 & & 47,6 & \\
\hline Bunga Deposito > 15\% & 22 & 31,8 & & 19,2 & & 20,0 & & 15,0 & & 21,4 & \\
\hline Nisbah Deposito (BPRS) & & & $60: 40$ & & - & & $55: 40$ & & & & $58: 42$ \\
\hline Jangkauan goegrafis & & & & & & & & & & & \\
\hline$\%$ BPR d / > 1 kantor & 15 & - & 0,0 & 6,4 & - & 22,8 & 100,0 & 23,8 & - & 13,2 & 50 \\
\hline Rata2 kec. Yg dilayani & 114 & 5,5 & 7,7 & 6,1 & - & 10,5 & 17,0 & 16,2 & - & 9,2 & 12,4 \\
\hline $\begin{array}{l}\text { \% BPR melayani => } 10 \mathrm{kec} . \\
\text { Tab. pd. kantor pusat BPR } \\
\text { di kec. Pusat }\end{array}$ & 36 & 24,1 & 66,7 & 17,2 & - & 40,0 & 100,0 & 47,6 & - & 31,6 & 66,7 \\
\hline$\%$ BPR d / > 75\% terkons. & 32 & 44,4 & 66,6 & 34,4 & 0,0 & 20,0 & 33,4 & 15,0 & 0,0 & 28,8 & 50,0 \\
\hline$\%$ BPR d / < 50\% terkons. & 54 & 25,9 & 0,0 & 41,3 & 0,0 & 65,7 & 66,6 & 60,0 & 0,0 & 48,6 & 33,3 \\
\hline $\begin{array}{l}\text { Kredit pd. kantor pusat BPR } \\
\text { di kec. Pusat } \\
\% \text { BPR d } />75 \%\end{array}$ & & & & & & & & & & & \\
\hline terkonsentrasi & 45 & 62,9 & 0,0 & 44,8 & 0,0 & 27,8 & 100,0 & 25,0 & 0,0 & 40,2 & 50,0 \\
\hline$\% \mathrm{BPR} \mathrm{d} /<50 \%$ & & & & & & & & & & & \\
\hline terkonsentrasi & 24 & 7,4 & 0,0 & 13,8 & 0,0 & 33,3 & 0,0 & 30,0 & 0,0 & 21,4 & 0,0 \\
\hline$\underline{\text { Tdk ada saingan }}$ & 17 & 31,0 & 0,0 & 13,8 & 0,0 & 5,6 & 0,0 & 9,5 & 0,0 & 14,8 & 0,0 \\
\hline Konsumen yg dilayani & & & & & & & & & & & \\
\hline Rata2 jml rek. Kredit & 113 & 266 & 165 & 486 & 0,0 & 882 & 858 & 2.307 & 0,0 & 887 & 512 \\
\hline Rata2 nilai Kredit (Rp. Juta) & 113 & 1,2 & 0,2 & 1,4 & 0,0 & 3,1 & 1,5 & 6,9 & 0,0 & 2,9 & 0,8 \\
\hline Rata2 jml rek. Tabungan & 111 & 589 & 355 & 1.738 & 0,0 & 2.975 & 2.494 & 10.495 & 0,0 & 3.383 & 1424 \\
\hline Rata2 nilai tab. (Rp. 000) & 111 & 383 & 85.097 & 197 & 0,0 & 677 & 623.051 & 466 & 0,0 & 437 & 354.074 \\
\hline Rata2 jml rek. Deposito & 107 & 12 & 7 & 21 & 0,0 & 87 & 46 & 378 & 0,0 & 107 & 26 \\
\hline Rata2 nilai Dep. (Rp.juta) & 107 & 4,8 & 41,0 & 10,3 & 0,0 & 13,9 & 610,0 & 52,0 & 0,0 & 18,3 & 326 \\
\hline
\end{tabular}


Tabel V.1a :

Pengawasan, Pelindungan Simpanan dan Asosiasi berdasarkan Provinsi

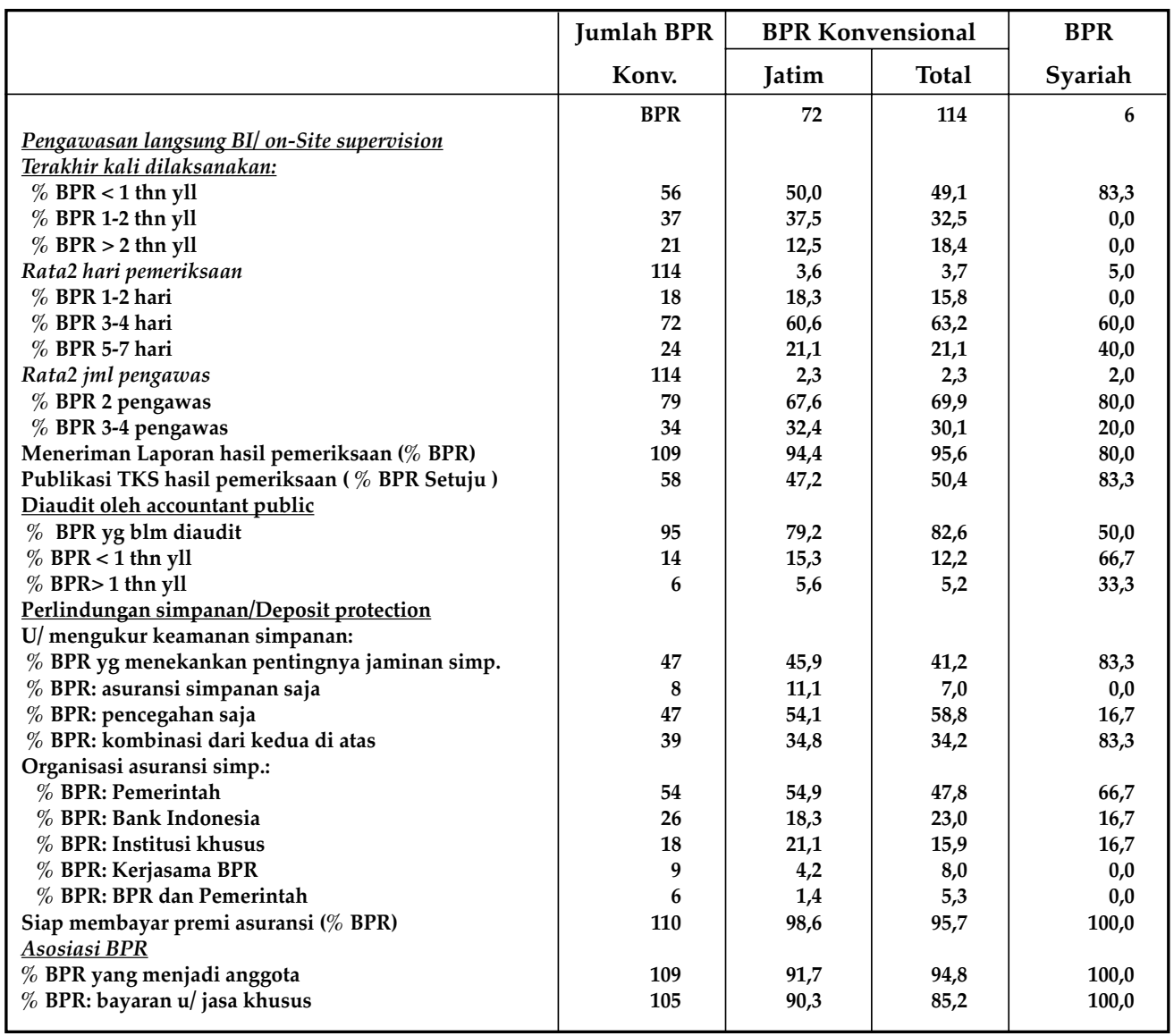

Tabel V.2a :

Rekomendasi untuk meningkatkan pengawasan BPR

\begin{tabular}{|c|c|c|}
\hline BPR Konv. (69) & BPR Sy. (6) & Rekomendasi \\
\hline $\begin{array}{r}20 \\
12 \\
11 \\
4 \\
3 \\
3 \\
\\
3\end{array}$ & $\begin{array}{l}3 \\
3 \\
- \\
1 \\
- \\
6\end{array}$ & 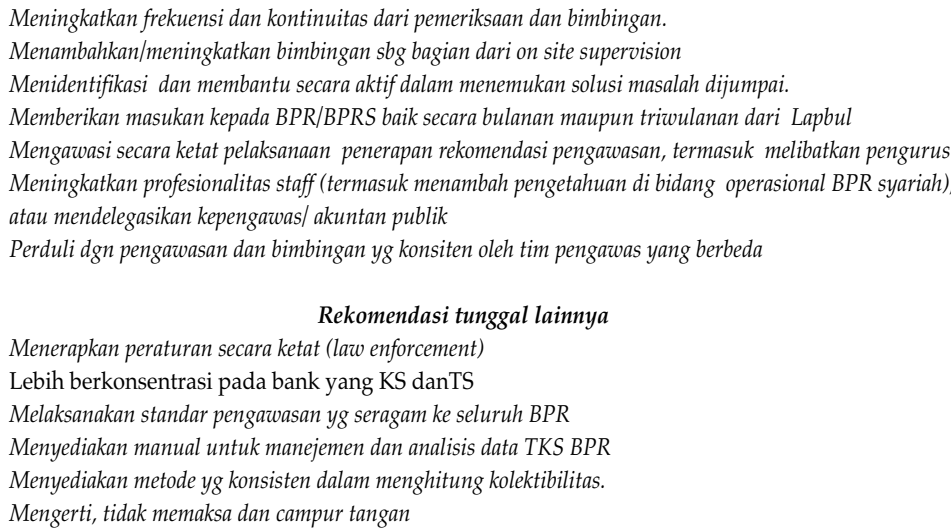 \\
\hline
\end{tabular}


Tabel V.3a :

Agumen pro \& kontra publikasi tingkat kesehatan bank

\begin{tabular}{|c|c|c|}
\hline BPR Konv. (54) & BPR Sy. (5) & Rekomendasi \\
\hline 20 & 4 & Memotivasi/menekan BPR untuk secara serius meningkatkan tingkat kesehatannya \\
\hline 15 & 5 & $\begin{array}{l}\text { Penting u/ mengiformasikan ke publik karena kesehatan bank adalah faktor penentu } \\
\text { kepercayaan masyarakat. }\end{array}$ \\
\hline 9 & 4 & Memungkinkan perbandingan antar BPR dan pesaingan timbul persaingan sehat \\
\hline 5 & 3 & Bank yg sehat membutuhkan keterbukaan, meningkatkan image bagi BPR Sehat. \\
\hline & & $\begin{array}{l}\text { Jawaban Ya lainnnya, dlmbentuk rangking BPR; meninformasikan kemajuan dari bimbingan BI; Ya, } \\
\text { hanya u/ diinformasikankepada nasabah saja; YA, terhadap laporan keuangan yang dipublikasi. }\end{array}$ \\
\hline BPR (46) & BPR Sy. (1) & KONTRA Arguments \\
\hline 17 & 1 & Rahasia dan kebutuhan internal antara BI \& BPR \\
\hline 11 & 1 & Menghambat peningkatan kesehatan bagi BPR KS dan TS \\
\hline 10 & 1 & Memprovokasi bank untuk di-rush, dan mempengaruhi BPR lainnya. \\
\hline \multirow[t]{2}{*}{3} & 1 & Umumnya menyebabkan image BPR menjadi negatif \\
\hline & & $\begin{array}{l}\text { Lainnya : Hasil penilaian BI bisa jadi salah; lebih baik mengenakan sanksi yg berat kpd BPR non } \\
\text { Sehat; Masyarakat desa belum mengerti informasi } \\
\text { kesehatan BPR; Laporan Laba Rugi telah dipublikasikan. }\end{array}$ \\
\hline
\end{tabular}

Tabel V.4a :

Pengawasan, Perlindungan Simpanan dan Assosiasi Berdasarkan Asset

\begin{tabular}{|c|c|c|c|c|c|c|c|c|c|c|c|}
\hline & \multirow{3}{*}{$\begin{array}{c}\text { Jml } \\
\text { BPR } \\
\text { Konv. }\end{array}$} & \multicolumn{8}{|c|}{ Kelas Asset } & \multirow{2}{*}{\multicolumn{2}{|c|}{ Total }} \\
\hline & & \multicolumn{2}{|c|}{ A } & \multicolumn{2}{|l|}{ B } & \multicolumn{2}{|c|}{$\mathrm{C}$} & \multicolumn{2}{|l|}{ D } & & \\
\hline & & BPR Konv. & BPRS & BPR Konv. & BPRS & BPR Konv. & BPRS & BPR Konv. & BPRS & BPR Konv. & BPRS \\
\hline Jml BPR & & 29 & 3 & 28 & 0 & 36 & 3 & 21 & 0 & 114 & 6 \\
\hline $\begin{array}{l}\text { BI Pengawasan lsg (on-Site sup.) } \\
\text { Terakhir kali dilaksanakan }\end{array}$ & & & & & & & & & & & \\
\hline$\%$ BPR $<1$ thn yll & 56 & 55,10 & 100,0 & 46,40 & 0,0 & 50,00 & 100,0 & 42,90 & 0,0 & 49,10 & 100,0 \\
\hline$\%$ BPR 1-2 thn yll & 37 & 27,60 & 0,0 & 35,70 & 0,0 & 33,30 & 0,0 & 33,30 & 0,0 & 32,50 & 0,0 \\
\hline$\%$ BPR > 2 thn yll & 21 & 17,20 & 0,0 & 17,90 & 0,0 & 16,70 & 0,0 & 23,80 & 0,0 & 18,40 & 0,0 \\
\hline Rata 2 hari pemeriksaan & 114 & 3,30 & 3,5 & 3,90 & 0,0 & 3,80 & 5,3 & 3,90 & 0,0 & 3,70 & 4,6 \\
\hline \% BPR 1-2 hari & 18 & 25,00 & 0,0 & 13,80 & 0,0 & 8,30 & 0,0 & 19,00 & 0,0 & 15,80 & 0,0 \\
\hline$\%$ BPR 3-4 hari & 72 & 50,00 & 100,0 & 72,40 & 0,0 & 77,80 & 33,3 & 42,90 & 0,0 & 63,20 & 60,0 \\
\hline \% BPR 5-7 hari & 24 & 25,00 & 0,0 & 13,80 & 0,0 & 13,90 & 66,7 & 38,10 & 0,0 & 21,10 & 40,0 \\
\hline Rata 2 jml pengawas & 114 & 2,00 & 2,5 & 2,10 & 0,0 & 2,40 & 2,0 & 2,70 & 0,0 & 2,30 & 2,2 \\
\hline \% BPR 2 pengawas & 79 & 92,90 & 50,0 & 85,70 & 0,0 & 58,30 & 100,0 & 38,10 & 0,0 & 69,90 & 80,0 \\
\hline$\%$ BPR 3-4 pengawas & 34 & 7,10 & 50,0 & 14,30 & 0,0 & 41,70 & 0,0 & 61,90 & 0,0 & 30,10 & 20,0 \\
\hline Meneriman LHP (\% BPR) & 109 & 96,60 & 100,0 & 92,90 & 0,0 & 94,40 & 66,7 & 100,00 & 0,0 & 95,60 & 83,3 \\
\hline Publikasi TKS hsl pmrksn & & & & & & & & & & & \\
\hline (\% BPR Setuju ) & 58 & 48,30 & 66,7 & 37,90 & 0,0 & 50,00 & 100,0 & 71,40 & 0,0 & 50,40 & 83,3 \\
\hline Diaudit oleh accountant public & & & & & & & & & & & \\
\hline$\%$ BPR yg blm diaudit & 95 & 82,80 & 66,7 & 93,10 & 0,0 & 91,70 & 33,3 & 52,40 & 0,0 & 82,60 & 50,0 \\
\hline$\%$ BPR $<1$ thn yll & 14 & 3,40 & 100,0 & 3,40 & 0,0 & 5,60 & 50,0 & 47,60 & 0,0 & 12,20 & 83,3 \\
\hline$\%$ BPR > 1 thn yll & 6 & 13,80 & 0,0 & 3,40 & 0,0 & 2,80 & 50,0 & - & 0,0 & 5,20 & 16,7 \\
\hline Perlindungan simpanan & & & & & & & & & & & \\
\hline $\mathrm{U} /$ mengukur keamanan simpanan: & & & & & & & & & & & \\
\hline $\begin{array}{l}\text { o Drk yg menekankan } \\
\text { pentingnya jmnn simp. }\end{array}$ & 47 & 48,3 & 100,0 & 38,0 & 0,0 & 42,9 & 100,0 & 33,3 & 0,0 & 41,2 & 100,0 \\
\hline \% BPR: asuransi simpanan & 8 & 10,3 & 0,0 & 6,9 & 0,0 & 8,6 & 0,0 & - & 0,0 & 7,0 & 0,0 \\
\hline \% BPR: ukuran pencegahan & 47 & 51,7 & 0,0 & 62,0 & 0,0 & 57,1 & 33,3 & 76,7 & 0,0 & 58,8 & 16,7 \\
\hline \% BPR: kombinasi dari keduanya & 39 & 38,0 & 100,0 & 31,1 & 0,0 & 32,3 & 66,7 & 33,3 & 0,0 & 34,2 & 83,3 \\
\hline Pengelola asuransi simp. & & & & & & & & & & & \\
\hline$\%$ BPR: Pemerintah & 54 & 64,3 & 33,3 & 41,4 & 0,0 & 37,1 & 66,6 & 52,4 & 0,0 & 47,8 & 66,7 \\
\hline$\%$ BPR: Bank Indonesia & 26 & 14,3 & 33,3 & 24,1 & 0,0 & 28,6 & 33,3 & 23,8 & 0,0 & 23,0 & 16,7 \\
\hline \% BPR: Institusi khusus & 18 & 14,3 & 33,3 & 20,7 & 0,0 & 20,0 & 0,0 & 4,8 & 0,0 & 15,9 & 16,7 \\
\hline \% BPR: Kerjasama antar BPR & 9 & 7,1 & 0,0 & 6,9 & 0,0 & 5,7 & 0,0 & 14,3 & 0,0 & 8,0 & 0,0 \\
\hline$\%$ BPR: BPR dan Pemerintah & 6 & - & 0,0 & 6,9 & 0,0 & 8,6 & 0,0 & 4,8 & 0,0 & 5,3 & 0,0 \\
\hline Siap membayar premi asuransi (\% BPR) & 110 & 93,1 & 100,0 & 100,0 & 0,0 & 94,4 & 100,0 & 95,2 & 0,0 & 95,7 & 100,0 \\
\hline Asosiasi BPR & & & & & & & & & & & \\
\hline \% BPR yang menjadi anggota & 109 & 86,2 & 100,0 & 93,1 & 0,0 & 100,0 & 100,0 & 100,0 & 0,0 & 94,8 & 100,0 \\
\hline Siap membayar iuran & & & & & 0,0 & & & & & & \\
\hline Rata2 Iuran ang. blnan (Rp.000) & 103 & 31,2 & 23,3 & 39,1 & 0,0 & 40,3 & 35,0 & 42,8 & 0,0 & 38,1 & 28,0 \\
\hline \% BPR: bayaran u/ jasa khusus & 105 & 86,2 & 100,0 & 89,7 & 0,0 & 83,3 & 100,0 & 81,0 & 0,0 & 85,2 & 100,0 \\
\hline
\end{tabular}


Tabel V.5a :

Pengawasan, Perlinungan Simpanan dan Asosiasi Berdasarkan kinerja Kredit

\begin{tabular}{|c|c|c|c|c|c|c|c|c|c|c|c|}
\hline & \multirow{3}{*}{$\begin{array}{c}\text { Jml } \\
\text { BPR } \\
\text { Konv. }\end{array}$} & \multicolumn{8}{|c|}{ Kelas Kinerja Kredit } & \multirow{2}{*}{\multicolumn{2}{|c|}{ Total }} \\
\hline & & \multicolumn{2}{|c|}{ A } & \multicolumn{2}{|c|}{ B } & \multicolumn{2}{|l|}{$\mathrm{C}$} & \multicolumn{2}{|c|}{ D } & & \\
\hline & & BPR Konv. & BPRS & BPR Konv. & BPRS & BPR Konv. & BPRS & BPR Konv. & BPRS & BPR Konv. & BPRS \\
\hline Jml BPR & & 39 & 2 & 15 & 1 & 31 & 2 & 29 & 1 & 114 & 6 \\
\hline BI on-Site supervision & & & & & & & & & & & \\
\hline Terakhir kali dilaksanakan & & & & & & & & & & & \\
\hline$\%$ BPR $<1$ thn yll & 56 & 48,8 & 100,0 & 40,0 & 100,0 & 48,4 & 50,0 & 55,2 & 100,0 & 49,1 & 100,0 \\
\hline$\%$ BPR 1-2 thn yll & 37 & 35,9 & 0,0 & 40,0 & 0,0 & 19,4 & 50,0 & 37,9 & 0,0 & 32,5 & 0,0 \\
\hline \% BPR > 2 thn yll & 21 & 15,4 & 0,0 & 20,0 & 0,0 & 32,3 & 0,0 & 6,9 & 0,0 & 18,4 & 0,0 \\
\hline Rata2 hari pemeriksaan & 114 & 3,4 & 5,0 & 3,7 & 4,0 & 4,0 & 4,0 & 3,9 & 4,0 & 3,7 & 4,6 \\
\hline \% BPR 1-2 hari & 18 & 20,5 & 0,0 & 20,0 & 0,0 & 9,7 & 0,0 & 13,8 & 0,0 & 15,8 & 0,0 \\
\hline$\%$ BPR 3-4 hari & 72 & 64,1 & 50,0 & 53,3 & 100,0 & 64,5 & 50,0 & 65,5 & 100,0 & 63,2 & 60,0 \\
\hline \% BPR 5-7 hari & 24 & 15,4 & 50,0 & 26,7 & 0,0 & 25,8 & 50,0 & 20,7 & 0,0 & 21,1 & 40,0 \\
\hline Rata2 jml pengawas & 114 & 2,3 & 2,0 & 2,3 & 2,0 & 2,4 & 2,0 & 2,2 & 3,0 & 2,3 & 2,2 \\
\hline \% BPR 2 pengawas & 79 & 65,8 & 100,0 & 73,3 & 2,0 & 67,7 & 100,0 & 75,9 & 0,0 & 69,9 & 80,0 \\
\hline \% BPR 3-4 pengawas & 34 & 34,2 & 0,0 & 26,7 & 0,0 & 32,3 & 0,0 & 24,1 & 100,0 & 30,1 & 20,0 \\
\hline LHP diterima (\% BPR) & 109 & 89,7 & 100,0 & 100,0 & 100,0 & 96,8 & 50,0 & 100,0 & 100,0 & 95,6 & 100,0 \\
\hline Publikasi TKS hsl pemerik. & & & & & & & & & & & \\
\hline (Setuju \% BPR) & 58 & 52,5 & 100,0 & 66,7 & 100,0 & 41,9 & 100,0 & 48,3 & 100,0 & 50,4 & 83,3 \\
\hline Diaudit o/ akuntan publik & & & & & & & & & & & \\
\hline$\%$ BPR yg blm diaudit & 95 & 75,0 & 50,0 & 93,3 & 100,0 & 83,9 & 0,0 & 86,2 & 100,0 & 82,6 & 50,0 \\
\hline$\%$ BPR $<1$ thn yll & 14 & 20,0 & 50,0 & - & 0,0 & 12,9 & 50,0 & 6,9 & 0,0 & 12,2 & 33,3 \\
\hline$\%$ BPR > 1 thn yll & 6 & 5,0 & 0,0 & 6,7 & 0,0 & 3,2 & 50,0 & 6,9 & 0,0 & 5,2 & 16,7 \\
\hline Perlindungan simpanan & & & & & & & & & & & \\
\hline $\begin{array}{l}\mathrm{U} / \text { mengukur keamanan } \\
\text { simpanan: }\end{array}$ & & & & & & & & & & & \\
\hline \% BPR yg menekankan & & & & & & & & & & & \\
\hline pentingnya jmnn simp. & 47 & 41,1 & 100,0 & 40,0 & 100,0 & 35,5 & 100,0 & 48,3 & 100,0 & 41,2 & 100,0 \\
\hline \% BPR: asuransi simpanan & 8 & 2,6 & 0,0 & 20,0 & 0,0 & - & 0,0 & 13,8 & 0,0 & 7,0 & 0,0 \\
\hline \% BPR: ukuran pencegahan & 47 & 58,9 & 50,0 & 60,0 & 0,0 & 64,5 & 0,0 & 51,7 & 0,0 & 58,8 & 16,7 \\
\hline \% BPR: kombinasi dr diatas & 39 & 38,5 & 50,0 & 20,0 & 100,0 & 35,5 & 100,0 & 34,5 & 100,0 & 34,2 & 83,3 \\
\hline Organisasi asuransi simp. & & & & & & & & & & & \\
\hline \% BPR: Pemerintah & 54 & 60,0 & 100,0 & 40,0 & 0,0 & 33,3 & 50,0 & 50,0 & 100,0 & 47,8 & 66,7 \\
\hline \% BPR: Bank Indonesia & 26 & 15,0 & 0,0 & 33,3 & 100,0 & 30,0 & 0,0 & 21,4 & 0,0 & 23,0 & 16,7 \\
\hline$\%$ BPR: Institusi khusus & 18 & 12,5 & 0,0 & 6,7 & 0,0 & 23,3 & 50,0 & 17,9 & 0,0 & 15,9 & 16,7 \\
\hline \% BPR: Kerjasama BPR & 9 & 7,5 & 0,0 & 6,7 & 0,0 & 10,0 & 0,0 & 7,1 & 0,0 & 8,0 & 0,0 \\
\hline \% BPR: BPR dan Pemerintah & 6 & 5,0 & 0,0 & 13,3 & 0,0 & 3,3 & 0,0 & 3,6 & 0,0 & 5,3 & 0,0 \\
\hline Siap membayar premi asuransi & & & & & & & & & & & \\
\hline$(\% \mathrm{BPR})$ & 110 & 95,0 & 100,0 & 93,3 & 100,0 & 96,8 & 100,0 & 96,6 & 100,0 & 95,7 & 100,0 \\
\hline Asosiasi BPR & & & & & & & & & & & \\
\hline \% BPR yg menjadi anggota & 109 & 92,5 & 100,0 & 93,3 & 100,0 & 93,5 & 100,0 & 100,0 & 100,0 & 94,8 & 100,0 \\
\hline Siap membayar iuran & & & & & & & & & & & \\
\hline Iuran blnan rata2 (Rp.000) & 103 & 37,4 & 35,0 & 36,2 & 0,0 & 43,5 & 22,5 & 34,6 & 25,0 & 38,1 & 28,0 \\
\hline \% BPR: Bayaran u/ jasa khusus & 105 & 87,5 & 100,0 & 93,3 & 100,0 & 80,6 & 100,0 & 82,8 & 100,0 & 85,2 & 100,0 \\
\hline
\end{tabular}


Tabel V.6a :

Fungsi dan Jasa yang diharapkan oleh Asosisasi BPR

\begin{tabular}{|c|c|c|}
\hline $\begin{array}{l}\text { BPR Konv. } \\
\text { (105) }\end{array}$ & $\begin{array}{l}\text { BPR Sy. } \\
\text { (6) }\end{array}$ & Fungsi dan Jasa \\
\hline 50 & 6 & $\begin{array}{l}\text { Memfokuskan diri pada Sumber Daya Manusia BPR dengan } \\
\text { mengkoordinir / menyediakan training. }\end{array}$ \\
\hline 22 & 6 & $\begin{array}{l}\text { Menyediakan jasa konsultasi, khususnya pada BPR yang berkinerja } \\
\text { buruk }\end{array}$ \\
\hline 18 & 4 & $\begin{array}{l}\text { Mengorganisasikan dan menyalurkan kepentingan dan aspirasi } \\
\text { seluruh anggotanya }\end{array}$ \\
\hline 17 & 1 & Menidentifikasi dan memfasilitasi akses terhadap dana murah \\
\hline 13 & - & $\begin{array}{l}\text { Mengorganisasikan pertukaran informasi melalui media yang } \\
\text { beragam }\end{array}$ \\
\hline 9 & 3 & $\begin{array}{l}\text { Mengukung peningkatan image BPR / termasuk memprosikan BPR } \\
\text { syariah (pada BPR syariah) }\end{array}$ \\
\hline 7 & 2 & $\begin{array}{l}\text { Mengembangkan/memfasilitasi bentuk dari lembaga perlidungan/ } \\
\text { penjaminan simpanan, atau mendelegasikan kepengawas/ akuntan } \\
\text { publik }\end{array}$ \\
\hline 3 & - & Memfasilitasi kerjasama antar BPR \\
\hline 3 & - & $\begin{array}{l}\text { Membangun sistem informasi (seperti DKM Bank Indonesia) } \\
\text { peminjam-peminjam nakal }\end{array}$ \\
\hline 3 & - & Mengembangkan standar pengajian dan sistem kerja \\
\hline 2 & - & $\begin{array}{l}\text { Berfungsi sebagai pengawas BPR, menggantikan fungsi pengawasan } \\
\text { Bank Indonesia }\end{array}$ \\
\hline
\end{tabular}

